\title{
¿TANIT * EN ESPAÑA?
}

\section{MARÍA CRUZ MARÍN CEBALLOS}

Universidad de Cádiz

\begin{abstract}
Este artículo trata de ser una revisión y puesta al día de los estudios sobre la diosa cartaginesa Tanit en la Península Ibérica, a partir de testimonios arqueológicos, conocidos de antiguo unos y resultado de recientes excavaciones otros. Se realizan asimismo algunas consideraciones en torno al culto de esta diosa y a sus adoradores, en relación con la presencia cartaginesa en el sur de la Península Ibérica.
\end{abstract}

This paper aims to review and bring to date the studies about the Carthaginian goddess Tanit in the Iberian Peninsula, handling the old known archaeological documents, and the results of new excavations. We also make some reflexions about the cult of Tanit and her worshippers, related to the presence of Carthaginian people in the south of the Iberian Peninsula.

Hace algunos años nos mostrábamos fráncamente escépticos sobre la posible existencia del culto a la púnica Tanit en España (MARÍN CEBALLOS, 1977) (1). Sin embargo, recientes descubrimientos, tanto en España como en el ámbito mediterráneo, nos han hecho recapacitar, y sobre todo volver a valorar viejos testimonios un tanto olvidados y manidos, pero nunca, quizá, bien estudiados. Ciertamente hoy sabemos algo más de Tanit, aunque no demasiado, ya que su culto tropieza con el mismo problema que el de los demás dioses del ámbito fenicio-púnico: la ausencia de textos. Sólo contamos

Queremos expresar nuestro agradecimiento a cuantas personas han colaborado generosamente a la realización de este trabajo: R. Corzo, M. J. Pena, M. Belén, R. Ramos, L. Abad, H. Bonet, E. Llobregat, M. Rabanal, D. Vaquerizo, etc.

(*) Pese a haber quedado definitivamente demostrada la pronunciación Tinnit para el nombre de la diosa de Cártago TNT, preferimos seguir utilizando este nombre, de ya larga tradición en la historiografía fenicio-púnica.

(1) Se han ocupado de este tema A. GARCÍA Y BELLIDO (1954, 1957, 1967), y más recientemente M. BENDALA (1986, 357-361). Sin embargo, la mayoría de los testimonios catalogados en estos trabajos proceden de Ibiza, que en nuestra opinión constituye un mundo aparte en el momento histórico estudiado, no siendo lícito mezclar tal documentación con la de la Península. con breves y lacónicas dedicaciones. No obstante y pese a este sin duda gravísimo obstáculo, la presencia de la diosa es patente en el ámbito estudiado, y pese a las dudas que naturalmente una evidencia de tal naturaleza plantea, es un derecho y una obligación de los estudiosos de estos temas tratar de ir avanzando paso a paso en una tarea difícil, oscura, y muchas veces ingrata, de la investigación iconográfica.

No pretendemos un estudio exhaustivo del culto a la púnica Tanit en la Península Ibérica. Esa es labor que habrá de ir realizándose poco a poco. Nuestra intención es mostrar de qué modo una serie de documentos arqueológicos, algunos hallados hace años, otros nuevos, pueden relacionarse con el culto a la diosa, e incluso ver en qué medida, de aceptarse tal atribución, estos testimonios peninsulares podrían ayudar a definir la personalidad y caracteres de la aún enigmática divinidad de Cartago. Lamentablemente carecemos de la prueba definitiva que confirme nuestras hipótesis: la inscripción dedicatoria sobre cualquiera de las piezas estudiadas, pero es obvio que contamos con otro tipo de evidencias que nos permiten avanzarlas. Para el lector hiperpositivista, advertimos que el carácter fluido 


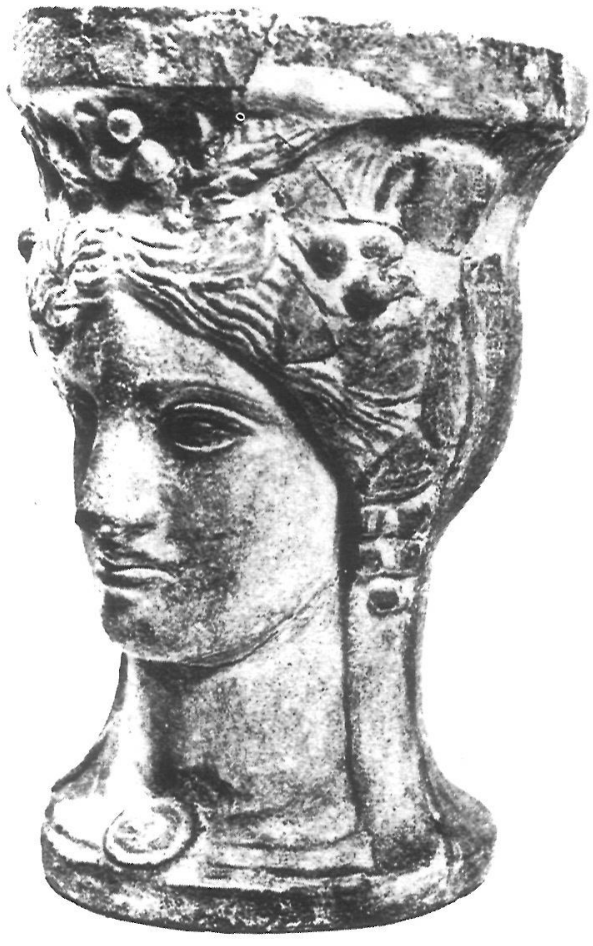

Lám. 1.-Pebetero de la necrópolis de la Albufereta (Alicante).

y huidizo de la materia tratada ha de asumirse previamente.

\section{PEBETEROS EN FORMA DE CABEZA FEMENINA}

Fueron estudiados hace años por Ana M. ${ }^{a}$ Muñoz quien, naturalmente limitada por las circunstancias de la investigación arqueológica en ese momento, llegó a la conclusión de que derivaban de modelos de la Magna Grecia, donde estarían conectados con el culto a Demeter y Kore. Ese mismo significado tendrían en la Península, distinguiéndose tres tipos: grequizante, de imitación y de influencia púnica. En cuanto a su fecha, irían desde fines del siglo IV a mediados del II antes de C., con una mayor abundancia en la segunda mitad del S. III y comienzos del II (MUÑOZ, 1963, 40-44).

Se trata de unos quemaperfumes o «pebeteros» de terracota en forma de cabeza femenina de rasgos claramente helénicos, con peinado en raya central y amplicas guedejas enmarcando el rostro, que en el tipo más frecuente se adorna con hojas y raci-

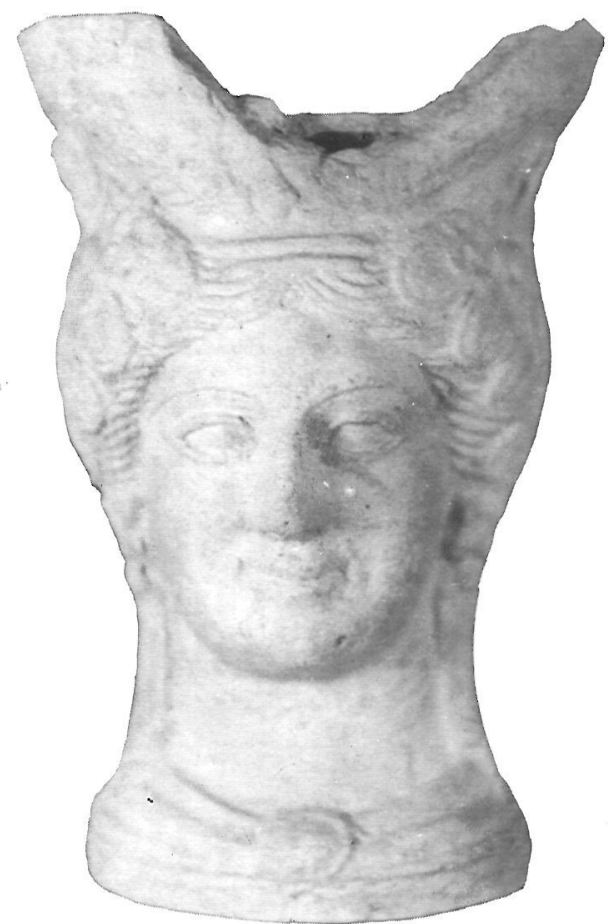

Lám. 2.-Pebetero procedente de Cádiz, en el Museo Arqueológico de Córdoba.

mos sobre el cabello y en la frente, a manera de diadema, con un motivo formado por tres glóbulos o frutos, flanqueado por dos palomas. Sobre el mismo llevan un kalathos de mediana altura en cuyo interior se observa una tapa horada por varios orificios, generalmente cinco. Las orejas suelen adornarse con racimos, a manera de arracadas, y enmarcan el cuello una especie de cintas o tirabuzones, lisos y planos. En su borde inferior se remata con unos pliegues, que simulan el reborde del vestido y un gran broche central de forma circular. No obstante, hay muchas variantes, desde las cabezas desprovistas totalmente de adornos, es decir, tan sólo el peinado en crenchas hacia arriba y el kalathos, hasta aquellas en las que los adornos se complican mucho más. se dan además muchos tipos que son claramente malas imitaciones locales, en que los motivos originales no pueden ya reconocerse. (Lám. 3)

Años más tarde de aquel trabajo, la propia Ana M. ${ }^{a}$ Muñoz rectificó sus conclusiones de manera notoria, afirmando que la difusión de dichos pebeteros coincide con los contactos comerciales y la presencia de los Barca en España a partir del 238 a. de C. (MUÑOZ, 1968). 
Estos trabajos precisan ya hoy ser revisados, incluyendo las nuevas piezas aparecidas dentro y fuera de la Península, lo que permitirá establecer una tipología, así como las relaciones con el resto de los ejemplares del Mediterráneo Occidental, para determinar con precisión el origen y vías de difusión de los mismos. Se trata de una labor de catalogación y estudio estrictamente tipológico, que tenemos emprendida y nos llevará algún tiempo. Nos interesa, no obstante, en el presente trabajo, llamar la atención sobre algunos puntos que consideramos de importancia vital para nuestro objetivo.

En primer lugar, hoy parece que está bastante claro que el prototipo de estos pebeteros hay que buscarlo en Sicilia, habiéndose documentado hasta el momento en la Acrópolis de Selinunte, datables en los siglos IV-III (BISI, 1966, 44 ss. nota 20) (2), así como en la necrópolis púnica del Lilibeo e incluso en Solunto (BISI, 1986, 292). En definitiva, en el área púnica de Sicilia. (Láms. 4-8)

Son muy abundantes en Cartago, sobre todo en la famosa fauissa excavada por el padre Delattre en Sidi-ben-Said (DELATTRE, 1924). En ella aparecieron más de 500 ejemplares, junto a fragmentos de estatuillas, asas de «braseros», ungüentarios, monedas, etc... Es importante anotar que se encontraba junto a la gran necrópolis de Santa Mónica (3).

Cerca de la estación de Salammbó, también en Cartago, excavó el Dr. Carton un santuario o capilla de gran interés para nosotros. Nos ocuparemos de él más adelante, pero es importante por ahora anotar que sobre una especie de consolas, había muchos quemaperfumes del tipo estudiado y junto a ellos se hallaron otros muchos restos de figuras

(2) La ciudad de Selinunte sufrió la dominación púnica a partir del 409, hasta mediados del siglo III. Sobre el tema véase DI VITA $(1953,39$ ss.) y TUSA, V. (1971, 47-68).

(3) El P. Delattre concedía especial importancia al hecho de que en esta colina de Sta. Mónica se hubiese encontrado años antes una inscripción púnica mencionando la dedicación de dos santuarios a Astarté y Tanit del Líbano y, cerca del lugar de hallazgo de la misma, los restos del templo romano de Ceres. Era idea de Ph. Berger y el propio Delattre, que dicho templo de Ceres se hubiera construido en las dependencias del viejo santuario de Astarté y Tanit, que luego fuera de Demeter y Kore, y más tarde Ceres, deduciendo de ahí un posible sincretismo entre Kore-Proserpina y Tanit (DELATTRE, 1898, 5 ss.). GSELL (1924 IV, 267, 347), se muestra cauto a este respecto, opinando que la presencia de la inscripción no demuestra la existencia allí de un santuario y, por otra parte, dado que ésta es del siglo III a. de C. no sería lógico esperar la existencia del mismo en el lugar de la necrópolis, fechada entre los siglos V-II a. de C.

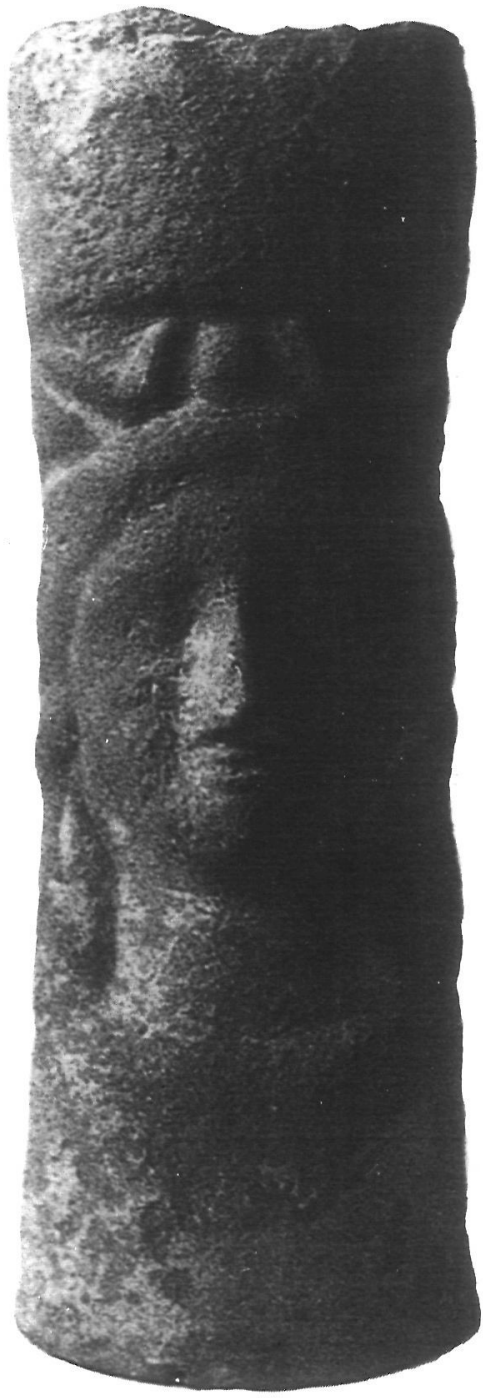

Lám. 3.-Pebetero del santuario del Castillo de Guardamar del Segura, Alicante.

votivas de terracota, una de las cuales es una cabeza varonil con barba y tiara de plumas, seguramente representación de $B a^{\prime} a l$ Hammon, así como una conocida figurita de marfil con falda de alas que $\mathrm{M}^{\mathrm{a}}{ }^{\mathrm{a}}$ Eugenia Aubet ha demostrado representa a Tanit (AUBET, 1976, 76). La fecha se fija entre el siglo IV y el asedio del 146 a. de C. (CARTON, 1929, n. 12,15 y 17 , p. 10-12, lám. V).

Pero también encontramos nuestros thymiateria en tumbas: así en la misma necrópolis de Santa Mónica (DELATTRE, 1906, 9), donde además apareció otro pebetero con cabeza de Heracles, semejante a uno de Tharros (ACQUARO, 1978, 81, fig. 6 a). De la del Odeón (siglos III-II a. de C.) pro- 


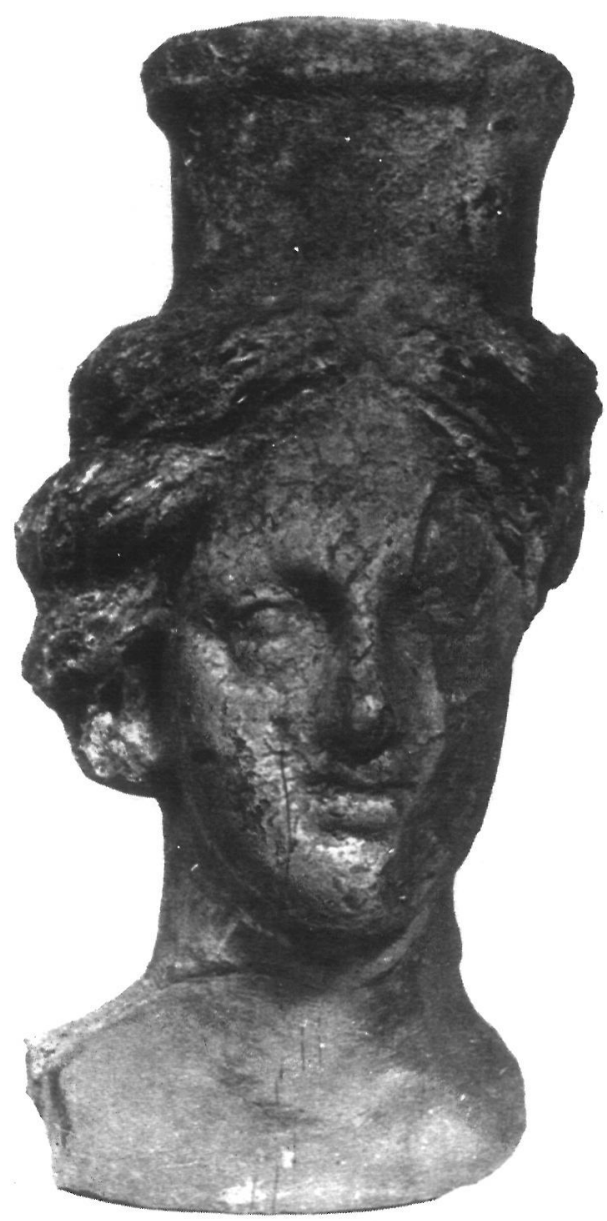

Lám. 4.-Pebetero siciliota. Palermo Museo Nazionale.

cede otro en forma de cabeza femenina (GAUCKLER ET ALII, 1910, 149, lảm. 75, 2; GAUCKLER, 1915, lám. CXCIII). También en la necrópolis de Byrsa (FERRÓN Y PINARD, 1955, láms. LIX y LXXXI, n. 97 y 154, p. 60 y 76, 1960-61, lám. LXXXI, n. 457-8, p. 153). (Láms. 9-10)

Los hay igualmente en otros lugares del Norte de África: así en Tamuda (TARRADELL, 1949, 86$100 ; 1956,71-85)$, que Cintas cree de fines del siglo II (CINTAS, 1954, 135, fig. 84, p. 73). El propio Cintas menciona otro en Korba, en un Santuario, junto con otras estatuas de terracota que afirma corresponden a Demeter, Persefone y Hades, actualmente en el Museo del Bardo (CINTAS, 1950, 553). Sin duda que un estudio minucioso de excavaciones y hallazgos recientes nos reportaría un número mucho más elevado de hallazgos.

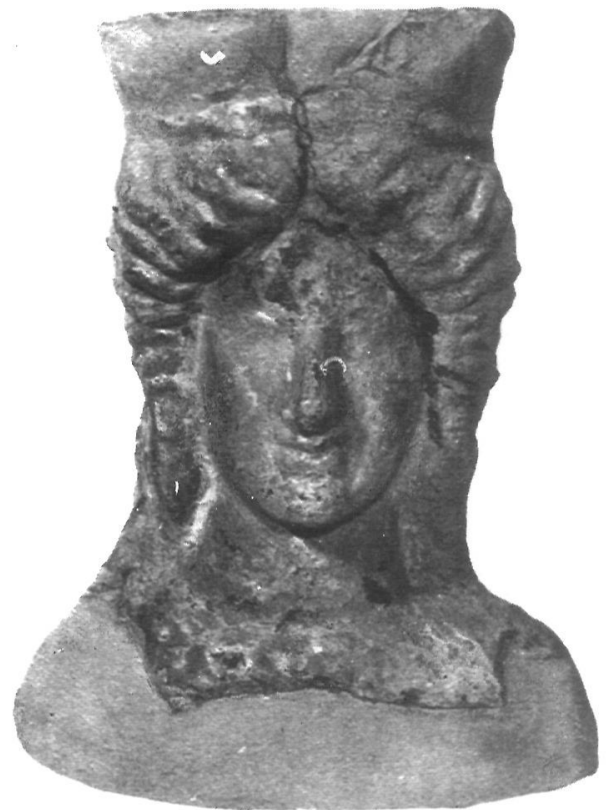

Lám. 5.-Pebetero siciliota. Palermo Museo Nazionale.

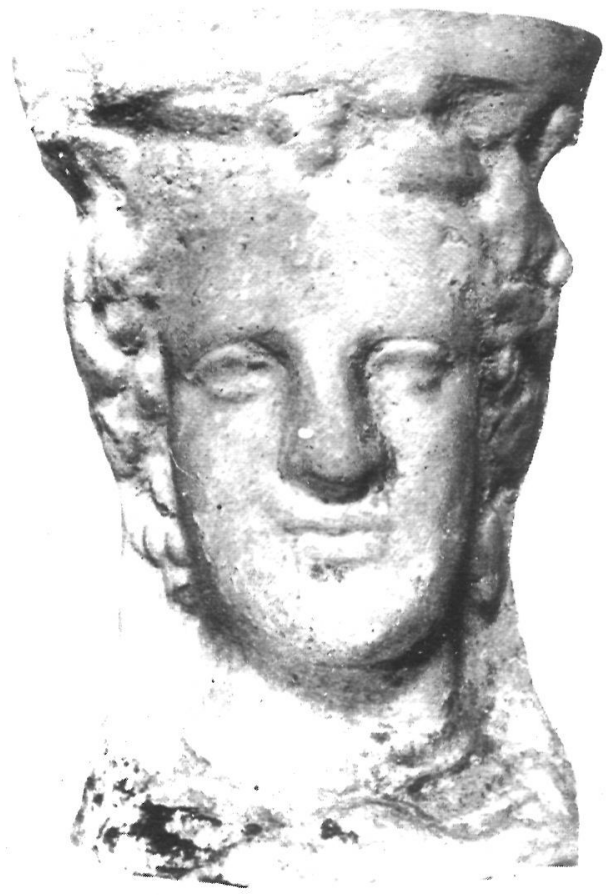

Lám. 6.-Pebetero siciliota. Palermo Museo Nazionale. 


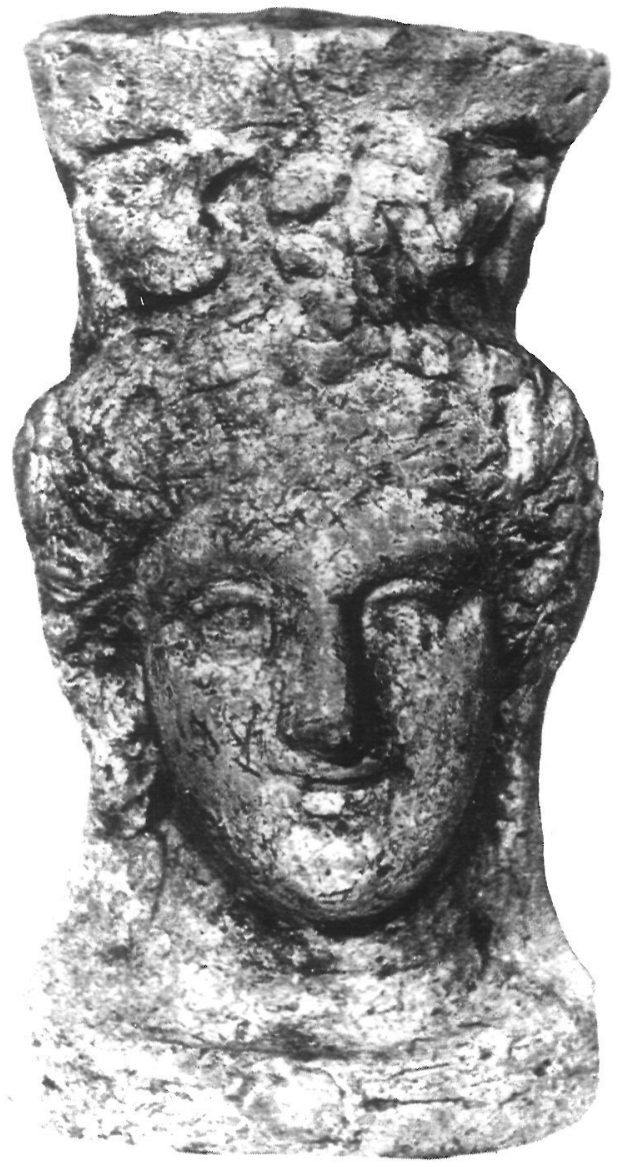

Lám. 7.-Pebetero siciliota. Palermo Museo Nazionale.

En Cerdeña los encontramos en varios lugares. Así, en el santuario púnico superpuesto a la nuraga Lugherras, en Paulilatino, aparecen en gran cantidad, desde el siglo $\mathrm{V}$ hasta época romana, junto con restos de huesos, monedas, carbones y cenizas (CECCHINI, 1969, 75-76). Tambien en Monte Sirai, en el llamado «sacello», junto al tophet, donde se muestran otros elementos que nos hablan del culto semítico. Los hay en el estrato $\mathrm{A}$ y en el $\mathrm{B}$, por lo que parece que existe una permanencia en el rito. Barreca los fecha en los siglos III-II a. de C. y piensa que, aunque los modelos sean greco-siciliotas, debe haberse dado un intermediario púnico, seguramente la propia Cartago (BARRECA, 1965, 59 y 74, lám. XIX).

Los hay igualmente en Tharros, en gran abundancia, y de un tipo muy característico llamado «de altar», ya que el kalathos adopta una forma cua-

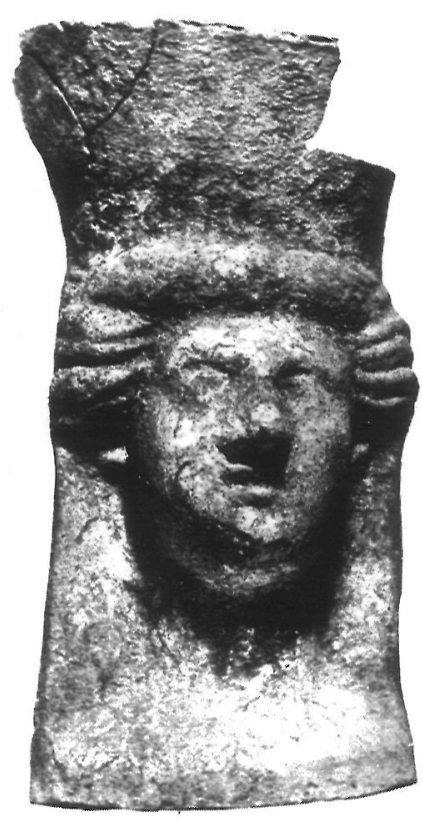

Lám. 8.-Pebetero siciliota. Palermo Museo Nazionale.

drada que recuerda la de los altares de perfumes en piedra que son frecuentes en el propio Tharros (MOSCATI, 1975, 31-33; 1980, 181-2). En algunos ejemplares se han sustituidos los símbolos usuales de la parte anterior del kalathos, palomas y frutos, por disco y creciente (ACQUARO, 1978, 81, figs. 5 b y c). Otros llegan a un alto grado de esquematización (UBERTI, 1975, 22-23, figs. A 58-134, láms. VII-XVII). Igualmente los encontramos en Sulcis (UBERTI, 1977, 30-31, lám. XV, figs. 13-16). Según noticias recientes los hay también en Olbia (4).

En Ibiza hay varios en la Cueva de Es Cuieram (AUBET, 1982, 30-32, lám. XXV, 1-4; ALMAGRO, M. J., 1980, 252, lám. CLXXIX, CLXXXI, CLXXXII, CLXXXIII), así como en Can Yai (Parroquia de San Lorenzo), lugar considerado igualmente un santuario (Ibidem. TARRADELL Y FONT, 1975, 128-9). También en Can Pis (San Rafael) y otros lugares (ALMAGRO, M. J., 1980 b, lám. LXIX, n. ${ }^{\circ}$ 121, 102-104: 1980 lám. CLXXIXX y CLXXX). En Mallorca, uno en el

(4) Debemos la noticia a M. J. PENA (1986). Al parecer se trata de un ejemplar fragmentario que fue hallado en el interior de un edificio que se cree santuario dedicado a Afrodita. 

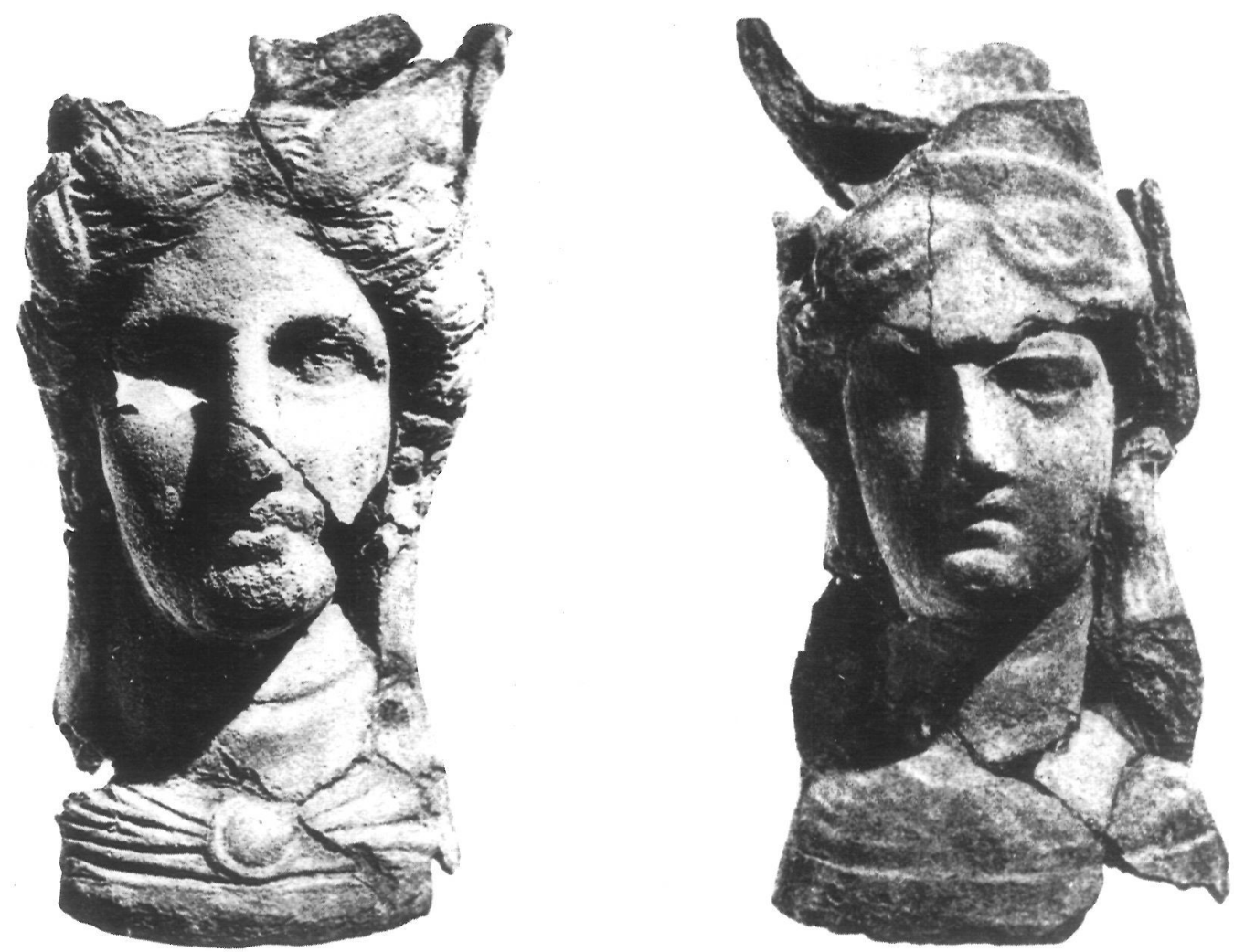

Lám. 9-10.-Pebeteros de la Colina de Byrsa, en Cártago.

Museo de La Alcudia que menciona A. M. ${ }^{a}$ Muñoz como procedente de las excavaciones de Pollentia (MUÑOZ, 1963, 29, 14).

Pasando ya a la costa ibérica, citaremos en primer lugar los de Ensérune (MOURET, 1929, 9, lám. 37, n. 34 y 35; UGOLINI, 1983, 101-108) y Rosas (MARTIN Y LLAVANERAS, 1980, 161). Un importante conjunto es el de Mas Castellà, de Pontós, a $12 \mathrm{Kms}$. de Figueras (Gerona). En el interior de un silo, aparecieron seis pebeteros, junto con ungüentarios fusiformes, cerámica ática, campaniense $\mathrm{A}$, etc... En el lugar, hasta ahora, no se ha detectado poblado alguno, sólo un campo de silos y un hogar ritual datable en la primera mitad del siglo IV (MARTIN Y LLAVANERAS, 1980; MARTÍN, 1979). Los thymiateria parecen todos salidos de un mismo taller y molde, y se caracterizan por llevar aletas laterales por debajo del kalathos y en la base del cuello (MARTÍN Y LLAVANERAS, 1980, 153-161; PENA, 1986). La fecha más antigua de los materiales del silo es de comienzos del siglo
IV, y el resto, de la segunda mitad del siglo III. En otro próximo, el n. ${ }^{\circ} 17$, apareció un pebetero del mismo estilo. En opinión de A. Martín y N. Llavaneras thymiateria y ungüentarios procederían todos de algún acto ritual y fueron depositados en el mismo momento (p. 158-159).

También en Ampurias hay un importante grupo de pebeteros. Dos fueron publicados por primera vez, sin conocerse su contexto, por Puig i Cadafalch (PUIG I CADAFALCH, 1915, 705-6, fig. 544). Otro por Bosch (BOSCH, 1937, 11, fig. XXVI), y tres por M. Almagro Basch, procedentes éstos de la necrópolis de Las Corts, y fechables entre fines del siglo III y mediados del II a. de C. (ALMAGRO BASCH, 1953, 345, fig. 327, 348, fig. 330, 379, fig. 348; MUÑOZ, 1963, 12-14).

Otros cinco ejemplares proceden de Ullastret, los tres primeros publicados por Oliva (OLIVA, 1955 , 380-381; 1956-7, 50, 60-61; 1959, 28, fig. 32) у A. M. ${ }^{a}$ Muñoz, con una datación entre los siglos IVIII a. de C. (MUÑOZ, 1963, 14-16) Del resto sólo 
se ha dado a conocer un dibujo (OLIVA, 1967, fig. 70; MARTÍN Y LLAVANERAS, 1980, 160-61, figs. 7 y 8 ).

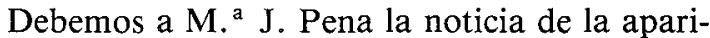
ción reciente de un pebetero en la necrópolis ibérica de Burriac, Mataró (PENA, 1986). En las proximidades de Barcelona tenemos igualmente el hallazgo de dos piezas en el poblado de Puig Castellar (Santa Coloma de Gramanet) (BOSCH, 1920, 593-596; MUÑOZ, 1963, 16-17; DE LA PINTA Y MIRANDA, 1981, figs. 1 y 3). Otro procedente del poblado del Turó de Can Oliver, Sardañola, Barcelona (BALIL, 1952; MUÑ̃Z, 1963, 17). Uno más del campo de silos de Can Fatjó de Rubí, en el Museo Arqueológico de Barcelona (COLOMINAS, 1915-20, 590-601; MUÑOZ, 1963, 18).

En el poblado de Castellet de Banyoles, en Tivisa (Tarragona), Serra Rafols encontró uno, actualmente en el Museo de Barcelona (SERRA, 1941, 15).

De gran importancia es el hallazgo casual en 1953, en el Bordisal de Camarles (Tortosa), de un depósito con «más de cincuenta estatuillas femeninas, la mayoría de ellas completas» (PALLARÉS, GRACIA Y MUNILLA, 1986, 123-149), junto con cerámica de barniz negro, lo que nos aproxima a una cronología entre comienzos y mediados del siglo IV a. de C. El conjunto fue dado a conocer por S. Vilaseca (VILASECA, S. 1956) y su hija L. Vilaseca, quien habla de más de 30 pebeteros y «algunas tanagras» (VILASECA, L. 1953-4, 355), lo mismo que A. M. ${ }^{a}$ Muñoz (MUÑOZ, 1963, 19). El número exacto es difícil de conocer ya que las piezas están dispersas entre los museos dle Barcelona, Tarragona y el municipal de «Salvador de Vilaseca» de Reus. R. Pallarés, F. Gracia y G. Munilla han publicado recientemente las ocho piezas conservarlas en este último museo, y al parecer preparan un trabajo sobre las cerámicas áticas halladas en el depósito (PALLARÉS, GRACIA Y MUNILLA, 1986). Según noticia de L. Vilaseca, en el lugar del hallazgo, en la margen derecha del barranco de Camarles, las figuras estaban amontonadas, sin orden alguno, en un espacio de planta más o menos cuadrangular de unos 2,30 por $1,20 \mathrm{~ms}$. Con ellas salieron algunos tiestos y restos de adobes, todo en una tierra negruzca y suelta (VILASECA, L., 1953$4,357)$. Parece que se trata de un depósito votivo, una de esas fauissae en que con tanta frecuencia se encuentran los pebeteros. Por el contrario, R. Pallarés et alii piensan en un depósito comercial en relación con un posible culto a la Demeter grecosiciliota, que se habría extendido por las costas catalanas y aragonesas paralelamente al desarrollo de la agricultura, como consecuencia a su vez de la difusión de ciertas técnicas y formas de cultivo por parte de una posible colonia griega de carácter agrícola, establecida en las bocas del Ebro. Todo esto en unas fechas de fines del siglo $\mathrm{V}$, comienzos del IV (PALLARÉS, GRACIA Y MUNILLA 1986, passim, 142 ss.).

Más al Sur, en las provincias de Castellón y Valencia, son menos abundantes los hallazgos, aunque ello no creemos tenga ninguna significación especial. Se ha argüido que ello puede deberse al hecho de que sean tan escasas las necrópolis detectadas en la provincia de Valencia, quizá porque el ritual utilizado no deja huella. Sin embargo pensamos que este argumento no es determinante, ya que hemos visto que en las provincias catalanas son mucho más abundantes los hallazgos y poblados y fauissae. Puede muy bien deberse al azar de los descubrimientos arqueológicos. No obstante, contamos con indicios seguros de su presencia: así, se hallaron dos fragmentos en La Monravana, al N. de Valencia, en excavación de D. Fletcher (inédito, noticia que debemos a Helena Bonet). Otro fragmento en el poblado del Castell (Almenara, Castellón) (SANMARTÍ Y GUSI, 1975, 167-70). Dos piezas casi completas en el poblado del Puntal dels Llops, en Olocau (Valencia) (BONET y MATA, 1981, fig. 48, láms. XVIII y XIX, 99 y 140-41). Otros fragmentos en el Castellet de Bernabé (Lliria) (BONET, 1978, 147-162, láms. I y II), en el Tossal de San Miguel (Lliria) y quizá en el Corral de Saus (Mogente) (5).

Ya en la provincia de Alicante empiezan a proliferar de nuevo los hallazgos. En primer lugar el conjunto que el padre Belda encontró en el Tossal de Polop o de la Cala (Benidorm), un pequeño montículo al que él llama «santuario» al aire libre, sin edificios, que estaría próximo al poblado, todo cubierto de restos de pebeteros del tipo estudiado (BELDA, 1946, 328 ss.) (6); (1950-51, 79 ss.; LLOBREGAT, 1972, 60-61). Recientemente el Prof. Tarradell, ha manifestado su opinión de que pueda

(5) Noticia que debemos a la amabilidad de H. Bonet.

(6) A pesar de que se ha dudado de la interpretación de Belda, recientes descubrimientos de pebeteros en pequeños montículos, han venido en cierto modo a darle la razón (véase más adelante, yacimientos de Coimbra del Barranco Ancho y Guardamar del Segura). 
tratarse de una necrópolis (TARRADELL, 1981, 117). E. Llobregat menciona también una pieza aparecida en la necrópolis romana tardía de El Campet, entre Mogente y Aspe (LLOBREGAT, 1974, 303-304). Igualmente considera de época baja el aparecido en las excavaciones de la Font Calent, en la gravera de una instalación romana tardía (LLOBREGAT, 1974, 304).

De gran interés para nuestro objetivo son las excavaciones que realiza E. Llobregat en el poblado de la «Illeta dels Banyets», término de Campello, en la costa alicantina. Allí se han hallado dos templos, el A, de planta rectangular, de tipo griego, y el $\mathrm{B}$, de planta cuadrada, que quizá fue más bien un patio abierto. En relación con este segundo templo o recinto sacro, un thymiaterion de los aquí estudiados (LLOBREGAT, 1981, 103 ss., figs. 1 y 2).

Un poco más al sur está la importante necrópolis de la Albufereta, donde aparecieron gran cantidad de pebeteros (Lám. 1). Afortunadamente, contamos hoy con la reciente tesis doctoral de F. Rubio Gomis (RUBIO, 1986), que permite aclarar en parte las dudas que planteaban las viejas excavaciones de Figueras y Lafuente (FIGUERAS, 1952, 179-194; 1956; LAFUENTE, 1934). Según Rubio Gomis, «todos los fechados se dan dentro del siglo IV, y son menos abundantes a fines de dicho siglo que a comienzos» (RUBIO, 1986, 360). Esta necrópolis reviste para nosotros un gran interés, ya que los pebeteros se acompañan a veces de otros elementos de claro origen púnico que confirman nuestras interpretaciones: así la gran tumba L-127-A, en que, además de tres pebeteros, aparece el busto femenino de terracota que estudiamos más adelante, de un tipo bien conocido en Ibiza y que en nuestra opinión representa con toda probabilidad a la diosa Tanit. Pero hay también otras terracotas de figuras femeninas en relación con niños y palomas que configuran el mismo ambiente (véase más adelante). Se fecha esta tumba en la primera mitad del siglo IV (RUBIO, 1986, fig. 97, 214-226).

De Elche, y concretamente de la colección Ibarra, procede un ejemplar que se conserva en el MAN (n. ${ }^{\circ}$ 17.652) (LAUMONIER, 1921 lám. CXX, 2, 203-4), hallado, según noticia de Ibarra y Manzoni (IBARRA Y MANZONI, 1879, 307), en una urna cineraria, junto con armas, en el llamado Cementerio Viejo, al parecer de cronología antigua (MUÑOZ, 1963, 23; LLOBREGAT, 1974, 303). Además, Ramos Folqués encontró numerosos fragmentos en La Alcudia, fechables entre los siglos III-
II a. de C. (MUÑOZ, 1963, 23; RAMOS FOLQUÉS, 1970, 35-36, n. ${ }^{\circ} 23$, lám. XIV a).

En las laderas del castillo de Guardamar (Alicante), se ha excavado recientemente un conjunto de pebeteros (Fig. 3). Como en el caso del Tossal del Polop, tampoco aquí hay restos de edificaciones (ABAD, 1985; 1986, 17-18).

Del mismo tipo es el yacimiento detectado en Coimbra del Barranco Ancho (Jumilla, Murcia): en las laderas de un cerro, aparecen numerosos fragmentos de thymiateria en forma de cabeza femenina, sin que hasta ahora se haya excavado en el lugar. Los fragmentos muestran que se trata de un tipo muy tosco, franca imitación local de matrices originales (MUÑOZ, 1985).

Siguiendo esta misma ruta de penetración interior y ya en la provincia de Albacete, se ha encontrado recientemente un ejemplar en el poblado de El Amarejo, Bonete, junto con un vaso en forma de paloma, en un departamento que sus excavadores consideran probablemente un almacén de cerámica, fechándolo a fines del siglo III (BRONCANO Y BLÁNQUEZ, 1985, lám. XXVII, fig. 284,251254, 291-292).

Según el reciente estudio de J. A. Santos Velasco, el material depositado en el MAN, como procedente de la supuesta «necrópolis ibérica» de Orán, podría haber pertenecido a una necrópolis del área contestana. En este conjunto hay algunos pebeteros, al parecer correspondientes a los tipos A y B de A. M. ${ }^{a}$ Muñoz, fechables entre fines del siglo IV y mediados del II (SANTOS, 1983, 338). Es interesante anotar también el hallazgo de una terracota que representa una mujer de pie con un niño en los brazos, y otra sedente, que estudiamos más abajo. Recordemos que figuras de este tipo aparecen también en las necrópolis de La Albufereta y Cabecico del Tesoro. Coincidimos por tanto con Santos Velasco en la lógica de su posible atribución al área contestana.

Junto a Murcia, en «El Verdolay» (La Alberca), se excavó hace años la necrópolis del Cabecico del Tesoro. Allí se hallaron 11 pebeteros que, según A. M. ${ }^{a}$ Muñoz, corresponden al tipo A, aunque de muy diversas calidades y tamaños. Muy interesante es el de la sepultura 86 , en piedra arenisca y de tosca realización, sin duda imitación de los anteriores (NIETO, 1939-40, 144, 148; 1943-44, lám. XI; 194445, 168, lám. XI; MUÑ̃Z, 1963, 25-26, láms. IVVIII). 
Siguiendo la línea costera hacia el Sur, es parada forzosa Villaricos, en Almería. Recientemente, M. $^{a}$ José Almagro ha dado a conocer un conjunto votivo procedente de dicho yacimiento, al parecer de un lugar situado fuera de la necrópolis (ALMAGRO, M. J., 1983, 291 ss.). Fue hallado por D. Luis Siret, $\sin$ que dejara constancia escrita del descubrimiento, siendo M. Astruc quien llamó la atención sobre el mismo (ASTRUC, 1962, 71-72). Parece que se trata de un simple agujero excavado en el terreno natural, seguramente una fauissa, lo que para M. ${ }^{a}$ J. Almagro indicaría la existencia en las proximidades de un templo o santuario dedicado al culto de Tanit. En el conjunto destacan los pebeteros de cabeza femenina, un centenar aproximadamente. La autora distingue hasta cuatro grupos o tipos, dos de ellos coincidentes con los A y B de A. M. ${ }^{a}$ Muñoz, y otros dos que constituirían variantes nuevas. Detalle importante es que algunos de ellos están abiertos por arriba y abajo, con lo que su carácter exclusivamente votivo es seguro. Junto a los pebeteros había también otras terracotas: dos que representan a Bes, una cabecita de toro y otras figuras masculinas y femeninas. $\mathrm{M}^{\mathrm{a}}{ }^{\mathrm{J}} \mathrm{J}$. Almagro fecha el conjunto entre los siglos III y II a. de C., pudiendo ser algo más viejas algunas piezas (ALMAGRO, M. J., 1983, 302). Ana M. ${ }^{a}$ Muñoz menciona otros dos pebeteros que cree procedentes de la misma necrópolis de Villaricos (MUÑOZ, 1963, 302).

De los alrededores de Málaga se conocen también varios ejemplares que, en realidad, y por lo que venimos viendo, deben ser indicios de la presencia de muchos más. Han sido recogidos por L. Baena de Alcázar; uno de ellos procede del Cerro de la Tortuga, a unos dos Kms. del casco urbano de Málaga, y está abierto en la base (BAENA, 1977, 741 ss.; 1977 b, 8-10, figs. IV-VII). El otro apareció en unos derribos en la propia ciudad de Málaga, a comienzos de siglo. Presenta los típicos asideros laterales (BAENA, 1977 b, 7-8, figs. 1-3).

Tenemos noticia de la existencia de otro pebetero procedente de Churriana, Málaga, aunque ignoramos los detalles de su hallazgo (SANTERO, 14) (7).

(7) A. M, MUÑOZ $(1963,28)$ menciona otro pebetero procedente de Fuente Toja, Córdoba, en el Ayuntamiento de Priego. Nuestras pesquisas en su búsqueda han resultado infructuosas. Agradecemos a D. Vaquerizo la ayuda prestada.
Por el momento, las piezas aparecidas más a Occidente son las del santuario de La Algaida, en Sanlúcar de Barrameda. Se trata de un conjunto de unos diez y seis fragmentos, dispersos por el área sagrada, algunos de ellos en uno de los pequeños «templetes» o «tesoros». Se ha recompuesto un ejemplar a base de varios fragmentos, resultando una pieza de buen arte, muy semejante a algunos ejemplares alicantinos. Su fecha podría estar entre los siglos VI y II, como el resto de los materiales del santuario. No obstante, algunas de las piezas podrían ser tardías (BLANCO Y CORZO, 1983, 125-126).

También de procedencia gaditana, aunque sin especificarse el lugar, es el ejemplar que se conserva en el Museo Arqueológico de Córdoba, de una colección particular (DE LOS SANTOS, 1950, lám. VII, n. ${ }^{\circ}$ 10.819). (Lám. 2)

Es obvia pues la enorme difusión que tales pebeteros alcanzaron en la Península, y éste es un hecho al que estimamos no se ha prestado la atención que merece. habría que considerar dos aspectos, muy interconectados entre sí:

- De un lado es necesario determinar las vías por las que han penetrado y se han difundido estos objetos, así como ver cuáles han sido sus modelos. Ello exige una laboriosa tarea de catalogación de todas las piezas con que contamos actualmente, no sólo en la Península, sino en el resto del Mediterráneo Occiental. Es un trabajo que tenemos emprendido y que verá la luz en un futuro próximo.

- Por otra parte, es preciso tratar de aclarar el significado cúltico de tales objetos, dentro del marco de las creencias de los íberos.

El primer punto es naturalmente vital, y nada puede resolverse definitivamente mientras no se realice ese trabajo previo. No obstante, con los datos actuales, podemos afirmar que tales pebeteros se atestiguan en la costa ibérica al menos desde comienzos del siglo IV, permaneciendo hasta época romana. No podemos precisar aún las vías que han seguido. E. Llobregat apuntaba hace unos años una procedencia ibicenca para los ejemplares levantinos (LLOBREGAT, 1974, 303-4, 319), lo que hoy día no parece probable dada la diversidad de tipos que aparecen en todo el ámbito ibérico, y su abundancia con respecto a Ibiza. Más recientemente, A. M. ${ }^{\mathrm{a}}$ Bisi sugería un origen directamente siciliota para los ejemplares de Ensérune, Ampurias, Verdolay y Camarles, mientras que otros serían el resultado del retoque de matrices importadas por los coroplastas 
locales (BISI, 1983, 148). Independientemente de la procedencia de las primeras matrices, creemos hoy día bastante claro que tuvo que haber cierto número de talleres en la propia Península, uno de los cuales pudo estar en Villaricos, y parece evidente que hubo también talleres indígenas de imitación. Pero todo será dar palos de ciego mientras no se cuente con un estudio tipológico completo. Lo que parece bastante probable es que el tipo se origine precisamente en la Sicilia púnica, en el área entre Selinunte y Lilibeo (BISI, 1966, 44-50; 1983, 148), y en nuestra opinión deriva de los grandes bustos de terracota utilizados en la Sicilia griega para el culto a Demeter y Kore. El hecho de que no encontremos estos tipos de thymiateria en ninguno de los thesmoforia, ni tampoco en las tumbas, del área griega de Sicilia, demuestra, en nuestra opinión, que se crean para un culto de índole no griega, en definitiva y para la época en que se inician, el culto en la púnica Tanit, cuyas relaciones con la pareja Demeter-Kore en Sicilia están todavía mal definidas.

Como es bien conocido, el culto a Demeter y Kore se introdujo en Cartago, procedente precisamente de Sicilia, en 396 a. de C. (Diodoro XIV, 77). Hace ya años, $P$. Cintas interpretó los pebeteros de este tipo aparecidos en Cartago como representaciones de la diosa o sacerdotisa kernophoros, portadora del kernos o crátera mística en las kernophoria o procesiones que se celebraban en los ritos eleusinos, con motivo de la fiesta de primicias, deduciendo de todo ello su relación con el culto a las diosas eleusinas (CINTAS, 1949, 115-119; 1950, 530 ss.) (8). Esta hipótesis de Cintas, en nuestra opinión, contribuyó a confundir los cultos de Demeter y Kore con el de Tanit, lo que es patente todavía en la bibliografía actual y, ciertamente, es difícil de evitar, cuando encontramos iconografías tan claramente «eleusinas» en relación con la diosa cartaginesa. Pero no debe extrañarnos tal fenómeno en la cultura fénico-púnica, baste con que echemos una ojeada a lo que ocurre en Ibiza, donde la abundancia de terracotas cuyos modelos proceden sin duda alguna del culto siciliota a Demeter y Kore, nos podría hacer pensar, de no estar avisados, que en la isla hubo un culto a estas diosas, tan importante como en la propia Sicilia griega, hecho que carece

(8) A. M. BISI (1966, 48-49) opina que tal hipótesis puede servir como explicación para el origen del tipo, pero no para su uso como thymiaterion. De la misma opinión se muestra PESCE $(1961,105)$. de toda lógica (BISI, 1978; MARÍN CEBALLOS, 1981, 105-65) (9).

No hay que perder de vista que toda esta confusión nace de la relación entre cartagineses y griegos en Sicilia, que hoy sabemos fue de profunda trascendencia en lo cultural, aunque es preciso determinar con exactitud sus consecuencias (HANS, 1983). Recordemos que en la realidad Demeter, y en especial Kore, se superponen en la isla a una diosa autóctona de la muerte y la renovación, lo que explica la acentuación de ese matiz en el culto siciliota de las diosas griegas (LÉVÊQUE, 1973, 48 ss.). Como sugieren Zunt (ZUNTZ, 1971, 157, nota 9), y también Bell (BELL, 1972, 3), las imágenes de esta Kore-Perséfone pueden haber servido a los cartagineses para representar a Tanit, diosa cuya relación con la muerte y la fecundidad es evidente. El kalathos o modius, atributo esencial de las diosas eleusinas, y en general de todos los dioses cotónicos, le corresponde pues plenamente, e incluso la forma del busto se ha interpretado como para dar la sensación de estar emergiendo de la profundidad de la tierra (ZUNTZ, 1971, 153 ss.).

Lógicamente, se plantea la cuestión de si no se habrá dado realmente, tal y como se ha dicho con frecuencia, una identificación o fenómeno sincretístico entre ambas divinidades, lo que sería de esperar dada la indudable proximidad de sus caracteres, así como la frecuencia con que las diosas griegas prestan su forma a la púnica Tanit. Un lugar, a nuestro entender clave, para esta posible identificación, es Selinunte, ciudad de la Sícilia griega que en el 409 a. de C. cayó bajo el dominio de Cartago. Mucho se ha escrito sobre el temenos de Demeter Malophoros, cuyo culto gozó de gran importancia desde el siglo VII hasta la caísa de la ciudad (GABRICI, 1927; TUSA, 1971, 47-68). Es a partir del 409 cuando se datan las «estelas» encontradas en el campo situado ante el pequeño recinto dedicado a Zeus Meilichios, dentro del temenos de la Malophoros. A. di Vita (DI VITA, 1961-64, 235-50; BISI, 1968, 46-47) supuso la interpretatio punica de ambas divinidades como Ba'al Hammon y Tanit, a quienes estarían dedicadas las estelas. Estas representan generalmente a una mujer y un hombre, desde las formas más estilizadas, casi anicónicas, hasta las

(9) No obstante, no queda en absoluto excluida la posibilidad de que hubiese en Ibiza, como en Cartago, un culto a las diosas eleusinas, tal y como apunta P. SAN NICOLÁS (1981, 27-33). 
propiamente helénicas, en que ambos aparecen claramente figurados como dos divinidades tocadas con el kalathos (10). Junto a estas estelas, otros elementos permiten a Di Vita pensar en el tophet púnico: la enorme acumulación de cenizas y huesos quemados de animales. D. White va más allá en su interpretación, y siguiendo la vía abierta por Di Vita, cree que el Megaron de la Malophoros fue también adaptado al culto púnico y sobre todo estima que, en determinados ambientes, puede darse una aproximación entre Demeter-Kore y Tanit (WHITE, 1967, 347 ss.; la réplica en PICARD, 1969, 480 ss.).

Otros autores dan pie para pensar en una cierta relación entre ambos cultos. Así, A. M. ${ }^{a}$ Bisi sugería hace años que quizá «la Tanit cartaginesa può aver assunto, in un periodo tardo e al contatto con la credenze religiose che si irradiavano dal mondo greco siceliota, un carattere funerario di protettrice dei morti e di garante di mistica ressurrezione» (BISI, 1966, 47; BISI, 1975, 27). Gsell, hablando de Demeter y Kore en Cartago, admite que quizá ambas diosas puedan haber recibido allí un nombre fenicio (¿Astarté?, ¿Tanit?) (GSELL, 1924, 346 ss.). G. Charles Picard niega la identificación, aunque cree que el culto a la Tanit cartaginesa ha tomado su forma definitiva bajo la influencia de los cultos mediterráneos de la diosa madre. En su opinión, la influencia más fuerte recibida es de la Hera suditálica (PICARD, 1954, 63-65).

Xella (XELLA, 1969, 225-227) se plantea la razón del atractivo del culto siciliota a Demeter y Kore para los cartagineses, y concluye que fue su relación con el mundo de la agricultura, más que su ideología escatológica y mistérica. La introducción del culto coincidiría con el desarrollo impreso a la agricultura de Cartago desde mediados del siglo V (GONZÁLEZ WAGNER, 1983, 298-300).

En definitiva, parece predominar la opinión de que ambos cultos no llegaron a identificarse, pero hay indicios de que puedan haber existido ciertos contactos entre ambas, problema que a su vez se relaciona con el de las Cereres graecae y las Cereres punicae de las inscripciones latinas del N. de África (LEGLAY, 1975, 136-7). En lo que sí están de

(10) Seguramente A. GARCÍA Y BELLIDO tenía presente estas estelas cuando, al estudiar los relieves aparecidos en la fauissa de Tajo Montero (Estepa, Sevilla), relacionaba aquella en que se muestran grabados un rostro masculino y otro femenino, con el culto a Baal Hammon y Tanit (1943, 171 ss.; 1957 , 473-76; BLECH, 1981, 99-109, fig. 5). acuerdo la mayoría de los autores es en el aprovechamiento por parte de los cartagineses de las matrices y modelos originarios del culto de Demeter, como de otras divinidades afines. Pero digámoslo con palabras de C. Picard: «Les représentations divines puniques qui sont parvenues jusqu'à nous, sont en effet conditionnées par leur caractère votif. Le but de l'image n'est donc pas d'incarner le dieu, mais de témoigner d'un acte pieux accompli par le dédicant, ou par la prêtre en son nom, acte censé dégager une énergie bénéfique qu'il convient de fixer et dont elle doit assurer la recharge pour un temps illimité. Dans cette optique, ce qui importe avant tout, c'est le geste ou l'objet qui définissent cet acte; l'attribut dévient ainsi l'insigne d'une fonction determinée et non blason, il est interchangeable. Il est alors indifférent de représenter Tanit sous les traits d'Isis, d'une dame grèque ou de Démeter portant Coré; un détail, les astres par example, une dédicace, une circonstance de lieu..., une prière particulière sufissent à identifier la divinité concernée...» (PICARD, 1969, 483; en el mismo sentido, BISI, 1966,47 y 1965, 102, 107, 155). Naturamente, parejo planteamiento supone una extrema dificultad para el estudio de la personalidad divina de Tanit.

Volviendo a nuestros pebeteros, hay que advertir que en un gran número de los mismos el kalathos que corona la cabeza de la diosa es también un thymiaterion o quemaperfumes, costubre ésta sin duda oriental, pero bien asimilada en la Península desde tiempos atrás, por obra precisamente de los fenicios. Nos interesa aquí recordar el hallado en una tumba ibicenca, el hipogeo de Can Pere Catalá des Port (Sant Vicent de Sa Cala), cuyos materiales han sido recientemente publicados por J. H. Fernández (FERNÁNDEZ, 1980, 9, fig. 1, lám. I). Su cuerpo central está formado por una cabeza femenina, de ancho cuello y rasgos bastante difusos, cuyo cabello la cubre como un casquete, con raya en el centro y dejando asomar dos protuberancias a manera de pendientes. En su parte inferior el cuello se ensancha para formar una peana circular sobre la que se asienta. Encima de la cabeza, un vástago macizo que soporta un gran recipiente en forma de cáliz. El conjunto mide unos $17,7 \mathrm{cms}$. de altura (Fig. 1). La tumba puede fecharse a comienzos del siglo IV. Un paralelo a este thymiaterion puede verse precisamente entre los materiales del santuario de Demeter Malophoros en Selinunte, del que sólo se conserva la cabeza y el cuenco o cáliz, faltándole la base. En este ejemplar selinuntino no existe el vás- 


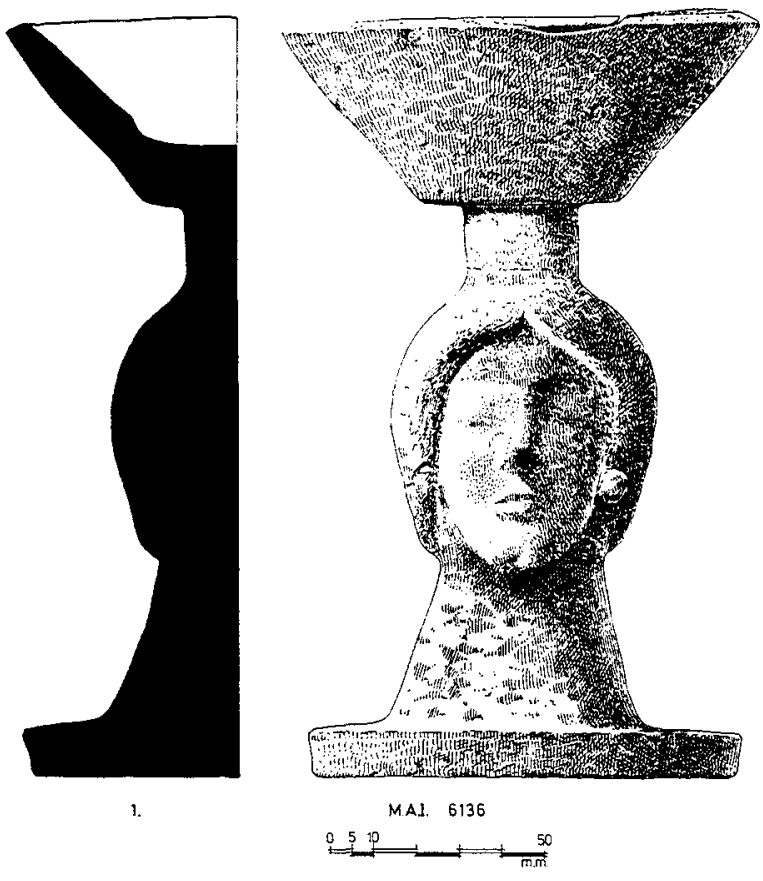

Fig. 1.-Thymiaterion del hipogeo de Can Pere Catalá des Port (San Vicent de Sa Cala, Ibiza) según J. H. Fernández.

tago de separación entre la cabeza y el cuenco caliciforme. L. Faedo que lo ha dado a conocer, observa cómo los thymiateria antropomorfos fueron producidos a gran escala en Selinunte (FAEDO, 1970, 4950 , lám. X, 1). Es posible que este tipo de pebetero constituya uno de los «pasos perdidos» hasta dar con el aquí estudiado, que logrará gran difusión.

C. Picard ha llamado la atención sobre unas figuras femeninas de terracota, todas ellas procedentes de la necrópolis cartaginesa de Santa Mónica. Se representan de pie, con larga túnica talar, siendo lo más notable en ellas la posición con los brazos en cruz, los puños cerrados y horadados, al parecer para sostener sendos cuencos a manera de pequeños quemaperfumes que se han conservado en un ejemplar del Museo Nacional de Cartago (PICARD, 1976, 155 ss. fig. 6) (11). Todas estas figuras se tocan también con alto kalathos, representando algunos

(11) En la Punta del Nao, Cádiz, y en excavaciones submarinas, se han hallado, formando parte de un conjunto de terracotas claramente votivo, tres figurillas femeninas, prácticamente iguales, muy estilizadas, de las cuales dos alargan los brazos al frente, con el puño horadado como para sostener algo. La tercera, en cambio, dirige el brazo hacia arriba, con la mano horadada igualmente. Nos preguntamos si no podrían haber sostenido pequeños cuencos a manera de pebeteros, como las figuras ejemplares muy estrecha relación en rostro y peinado en trenzas, a la moda africana, con las figuras acampanadas estudiadas por M. ${ }^{a}$ E. Aubet en Es Cuieram, en Ibiza (AUBET, 1982, fig. 7, cat. N. ${ }^{\circ} 13$, 163). La propia $C$. Picard relaciona estas figuras con el thymiaterion más arriba mencionado del santuario de La Gaggera en Selinunte. Concluye dicha autora, que las figuras citadas podrían responder a uno de los tipos iconográficos de Tanit (ibidem, 171).

En nuestra opinión, existe una estrecha relación entre las estatuillas de Santa Mónica y nuestros pebeteros; pero además, estos se emparentan con las figuras acampanadas de la cueva de Es Cuieram de Ibiza, hasta tal punto que M. ${ }^{a}$ E. Aubet plantea la posibilidad de que tales figuras deriven de ellos (AUBET, 1976, 65). Del mismo modo, existe una conexión entre estas figuras acampanadas y las imágenes aladas de Tanit estudiadas por la propia Dra. Aubet, ¿Es que hay una relación específica entre Tanit y el rito de quemar perfumes? Es bien conocida la importancia vital del mismo en el ritual fenicio-púnico, hasta el punto de que uno de los rasgos que definen invariablemente una iconografía divina de tal origen, es la presencia del thymiaterion. Pero también parece tener un papel clave en el ritual del tophet, ya que es normal su presencia en las estelas. El propio nombre de $B a^{\prime} a l$ Hammon ha sido interpretado a veces como «señor del altar de perfumes» (FÉVRIER, 1956, 19 ss.). Es posible pues que haya una significación concreta en el hecho de representar a la diosa como thymiaterion. En este sentido habría que referirse al reciente hallazgo del templo de la Illeta dels Banyets, en Alicante, que estudiamos más abajo.

De lo hasta aquí expuesto creemos se desprende, sin forzarla en absoluto la siguiente conclusión: los pebeteros llamados «de cabeza fenicia» son una creación de la Sicilia púnica, evidentemente inspirados en los bustos de terracota utilizados en el culto a Demeter y Kore (TUSA CUTRONI, 1968, 11920) (12). Los adornos del kalathos: frutos y aves, que a veces se convierten en espigas, hojas de hie-

de Sta. Mónica (BLANCO, C. 1970, 50 ss.; RAMÍREZ Y MATEOS, 1982; MARÍN CEBALLOS, 1983, 19-22). Aprovechamos la ocasión para subsanar la omisión, en este último trabajo citado, de las excavaciones realizadas por J. R. Ramírez y su equipo en el citado yacimiento, que no conocíamos al no existir aún en ese momento publicación científica de las mismas. Del mismo modo, se incluye por error en ese mismo trabajo una cabeza de negroide procedente de San Fernando (Cádiz) (lám. 3). 


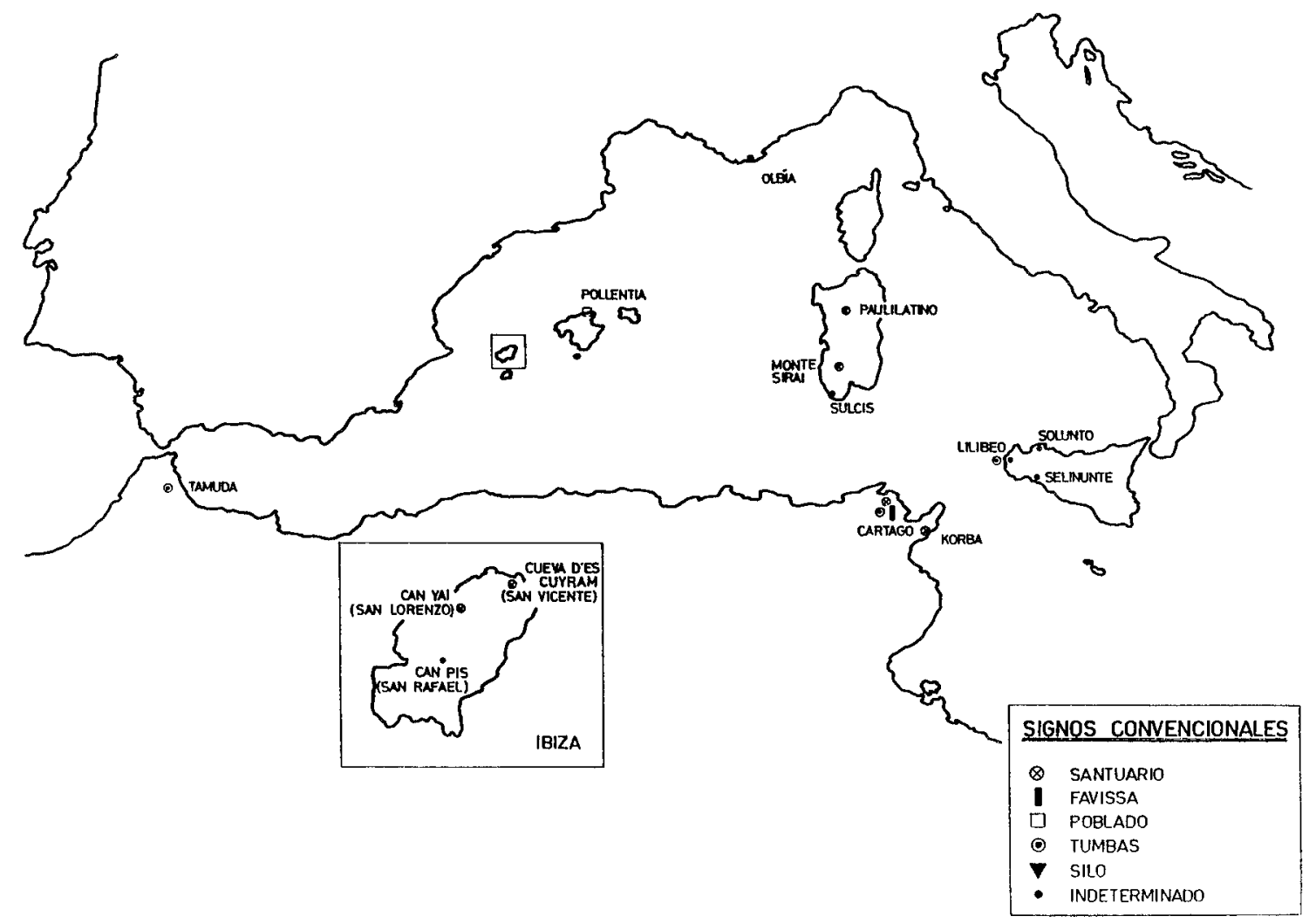

Mapa n. ${ }^{\circ}$ 1: Dispersión de los pebeteros en el Mediterráneo.

dra y racimos de vid, evocan concepciones de tipo iniciático que, como bien vio A. M. ${ }^{\mathrm{a}}$ Bisi, se desarrollarán ampliamente en el período neopúnico sobre las estelas norteafricanas (BISI, 1966, 49). la misma disposición de hojas de hiedra y racimos de vid en diadema o guirnalda, sobre la parte anterior del cabello, podemos observarla en el tocado del Dionisos joven representado en la fina lámina de marfil que se encontró en una tumba de la necrópolis de Santa Mónica, en Cartago (Fig. 2), y que, según C. Picard, refleja la imagen que los griegos del siglo IV tenían del dios (PAICARD, 1979, 83-

(12) A. TUSA $(1968,119-20)$ se inclina a considerar a Cartago como centro creador y propulsor de estos thymiateria, aunque obviamente inspirados en el ambiente artístico y religioso siciliota. Una vez más, estimamos que no podrá darse una respuesta válida a esta problemática en tanto no se realice el trabajo de catalogación que proyectamos.
84). Hédera y racimos de vid son también representados con relativa frecuencia en las estelas púnicas, en ocasiones, incluso, flanqueadas por palomas ( $i b i$ dem, fig. 4, CB 449, fig. 5).

La simple distribución de los pebeteros en el Mediterráneo Occidental (que puede observarse en nuestros mapas) demuestra con toda claridad el carácter púnico de los mismos: la Sicilia Occidental, Cartago y N. de África, centros púnicos de Cerdeña, Ibiza, y toda el área hispana donde se da la cultura ibérica, incluyendo algunas de las colonias púnicas del Sur.

No cabe duda de que el área donde adquieren mayor difusión es la costa oriental hispana. ¿Supone esto la expansión del culto a Tanit entre los iberos? Sin duda, no estamos en condiciones aún de responder a esta pregunta. Por el momento, nos contentaremos con dejar constancia de una serie de hechos que pueden ser ilustrativos. 


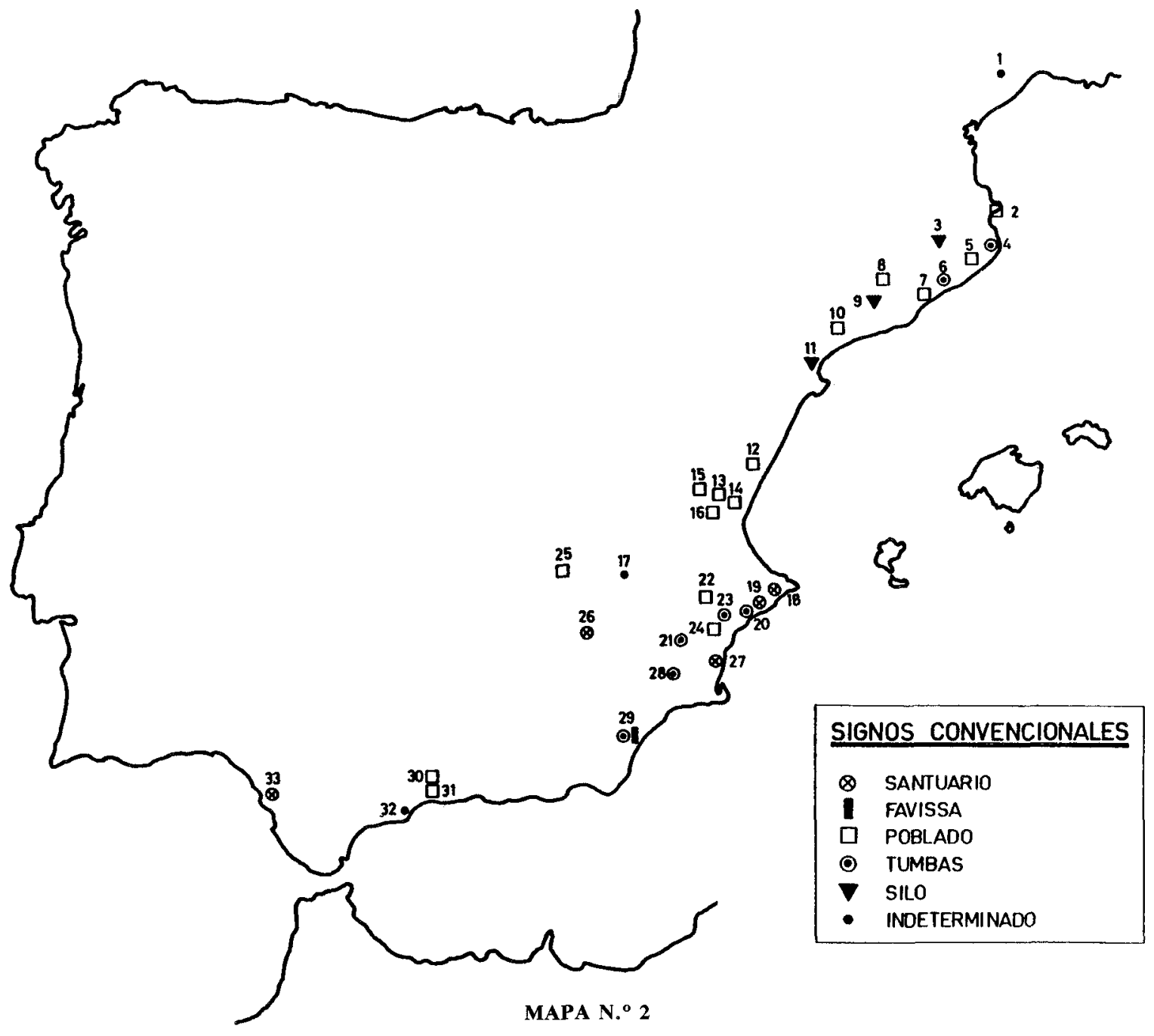

Difusión de los pebeteros en forma de cabeza femenina en la Península Ibérica

1. Ensérune. 2. Rosas (Gerona). 3. Mas Castellà de Pontós, Figueras (Gerona). 4. Ampurias (Gerona). 5. Ullastret (Gerona). 6. Burriac, Mataró (Barcelona). 7. Puig Castellar, Santa Coloma de Gramanet (Barcelona). 8. Turó de Can Oliver, Sardañola (Barcelona). 9. Can Fatjó de Rubí (Barcelona). 10. Castellet de Banyoles, Tivissa (Tarragona). 11. Bordisal de Camarles, Tortosa (Tarragona). 12. Castell, Almenara (Castellón). 13. Puntal dels Llops, Liria (Valencia). 14. La Monrava, Liria (Valencia). 15. Castellet de Bernabé, Liria (Valencia). 16. Tossal de San Miguel, Liria (Valencia). 17. Mogente (Valencia). 18. Tossal de Polop o de la Cala, Benidorm (Alicante). 19. Illeta de Banyets (Alicante). 20. Albufereta (Alicante). 21. El Campet, Monforte del Cid (Alicante). 22. La Font Calent (Alicante). 23. Elche, cementerio viejo (Alicante). 24. La Alcudia de Elche. 25. El Amarejo, Bonete (Albacete). 26. Coimbra del Barranco Ancho, Jumilla (Murcia). 27. Guardamar del Segura (Alicante). 28. Cabecico del Tesoro, Verdolay (Murcia). 29. Villaricos (Almería). 30. Cerro de la Tortuga (Málaga). 31. Málaga. 32. Churriana (Málaga). 33. La Algaida, Sanlúcar de Barrameda (Cádiz)

Anotemos que se encuentran con frecuencia en tumbas, especialmente en el Sudeste; en poblados, quizá en contextos religiosos; en fauissae, que posiblemente supongan la proximidad de templos o lugares sagrados; y sobre todo en un tipo de santuarios, hasta ahora mal definidos, pero que merece la pena estudiar en profundidad. Se trata de pequeñas elevaciones sobre cuyas laderas aparecen grandes can- tidades de pebeteros, sin que se hayan observado hasta ahora restos de construcciones: Guardamar del Segura, Coimbra del Barranco Ancho, Tossal de Polop. Todo parece indicar que se trata de santuarios en lugares altos y al aire libre, en definitiva según la costumbre ibérica, a la manera de los de Collado de los Jardines, Castellar de Santisteban, La Serreta, etc. La constatación de este hecho puede 


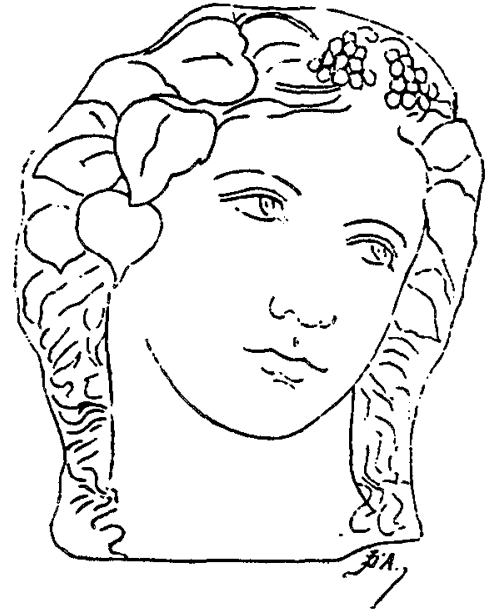

Fig. 2.-Cabeza de Dionisos joven grabada sobre marfil, procedente de la necrópolis de Santa Mónica, Cártago.

resultar muy significativa para apreciar el grado de asimilación por los iberos de un culto que, en su origen, debió ser cartaginés.

De excepcional importancia cara a la valoración de estos objetos, es el hallazgo reciente de dos templos, excavados por E. Llobregat y su equipo en la Illeta dels Banyets, en Campello, Alicante (LLOBREGAT, 1981, 1983, 1985). El llamado templo A parece ser de estructura in antis, con dos columnas en el frente, pronaos y triple cella al fondo. La pared interior del mismo estaba revestida de pintura roja. En su interior aparece cerámica ática de barniz negro, junto con cerámica ibérica. Otro dato de interés es un fragmento de cabeza masculina en piedra de unos $20 \mathrm{cms}$. de alzada, que Llobregat piensa pueda corresponder a una imagen de culto. Al otro lado de la calle, frente a dicho templo, se ha descubierto un edificio que su excavador interpreta como almacén o «tesoro» del templo. A poniente del citado almacén apareció posteriormente otro edificio al que Llobregat denomina templo B que, en interpretación del mismo, conoció dos fases: En la superior o reciente, su muro oriental es parelelo al zaguero del almacén, separado de él por un estrecho callejón. Del edificio, sólo se conservan los muros Este y Norte, y parece que careció de cubierta. En su interior, que debió tener unos $7 \mathrm{~ms}$. en sentido N-S y 6,50 E-N, aparecen varias plataformas ocupando el centro geométrico del mismo, que Llobregat piensa sirvieron de base o soporte al altar de perfumes hallado en el recinto. Cree también el arqueólogo que pudo haber en el mismo cen-

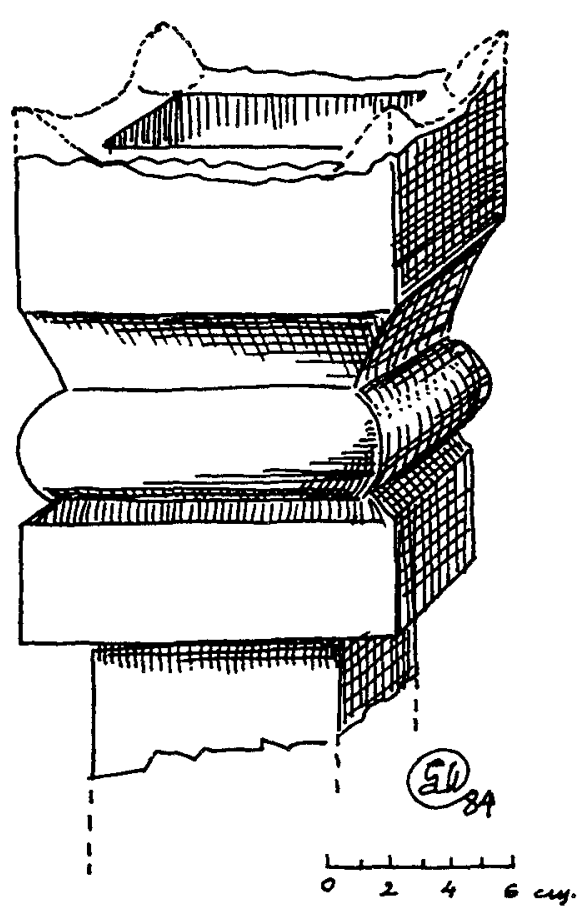

Fig. 3.-Altar de perfumes del templo de la Illeta dels Banyets, El Campello, Alicante, según E. Llobregat.

tro una ashera, por haberse hallado un tambor de columna con un pequeño rebaje de forma circular, que permitiría alzar sobre él otro elemento, seguramente de madera. Otra pieza importante es un pebetero de los aquí estudiados.

En cuanto al altar de perfumes (véase fig. 3) es de piedra caliza, muy oscurecida por la acción del fuego. Preferimos seguir la descripción de Llobregat: «Está extraído de un prisma cuadrangular de $0,12 \mathrm{~m}$. en cuadro y de altura incierta pues la parte inferior está truncada y la altura conservada es de $0,16 \mathrm{~m}$. De arriba abajo se puede observar la capa superior, cuadrangular, con huellas de cuernos en los ángulos, muy quemada en su parte interna también cuadrada; apea en un tronco de pirámide de muy escasa altura apoyado en un baquetón cuadrado. De éste nace hacia abajo un prisma cuadrangular de dimensión mucho más reducida $(0,09$ de cuadro), que hace a modo de espiga y que se trunca de inmediato». (LLOBREGAT, 1984, 301-305).

Llobregat menciona paralelos de Cartago, Villaricos e Ibiza. Pero quizá el paralelo más llamativo, por el contexto, es el encontrado en el templo excavado por L. Carton en las proximidades de la estación de Salambó, en Cartago. Se trata de una cons- 
trucción que, en el momento de destruirse, consistía en una sala rectangular precedida por una parte más estrecha, y bordeada en todos sus lados por una banqueta. En el fondo, una muy rica decoración en yeso estucado, formaba una columnata dórica en cuyo interior se elevaba un zócalo o pedestal. A cada lado, consolas sobre las que había pebeteros en forma de cabeza femenina. Toda la decoración estucada se coloreaba de rojo, en paneles encuadrados por una línea negra. En su interior aparecieron muchos objetos de terracota: grandes bustos femeninos modiados, pebeteros del tipo estudiado, silenos, figuras de guerreros, lucernas, fragmentos de figuras masculinas y femeninas diversas, algunas de ellas entronizadas, etc. (CARTON, 1929). Entre todo este material, un pequeño altar de perfumes semejantes al de la Illeta dels Banyets (ibidem, pl. V, 9, p. 12, N. $\left.{ }^{\circ} 18\right)$. La fecha asignada por Carton al templo es de los siglos IV-III a. de C. Cree que fue destruido violentamente a mediados del siglo I de la Era, en el asedio de Cartago. También en la datación coincide con el templo alicantino. De todo ello deducimos una relación evidente entre ambos, que viene a corroborar nuestras ideas sobre el particular. En todo caso, esperamos la publicación definitiva del conjunto de la Illeta por parte de Llobregat.

En cuanto al «santuario» de La Algaida (Sanlúcar de Barrameda, Cádiz), tenemos el inconveniente de que aun no se ha publicado, salvo una breve noticia divulgativa (BLANCO Y CORZO, 1983, 123-128). En ella, R. Corzo y A. Blanco ponen el yacimiento en relación con los topónimos que hacen referencia a Venus, en la desembocadura del Guadalquivir, así como el santuario de Phosphoros o Lux Dubia de Estrabón (III, 1,9). De ser éste realmente el lugar, habría que pensar más en Astarté que en Tanit, ya que aquélla es la diosa del planeta Venus y por tanto Phosphoros, es decir, la estrella de la mañana (13). El yacimiento parece originarse en el siglo VII, llegando aproximadamente hasta el 212 a. de C. No obstante, el momento más interesante parece se da en el nivel IV, que empieza a formarse hacia el 500. No hay un edificio importante, sólo pequeñas casetas o «tesoros», abundando las

(13) Recientemente J. M. LUZÓN y L. M. COÍN han llamado la atención sobre la importancia de la navegación por los astros y su utilización por los fenicios en sus viajes al extremo Occidente (1986, en prensa). Ello explicaría la serie de topónimos con advocaciones astrales de nuestra costa Sur. Sobre el tema véase CHAVES Y MARÍN CEBALLOS (1987, en prensa). ofrendas de todo tipo. No obstante, como anotan Corzo y Blanco, los pebeteros en forma de cabeza femenina se dan en elevada proporción con respecto a los demás exvotos, lo cual, en su opinión, no es indicio de que el objeto de culto fuera esta diosa. Abundan igualmente los anillos, que podrían considerarse ofrenda típica de mujeres, lo mismo que los objetos de tocador y maquillaje, y del mismo modo las terracotas que representan a una mujer de pie con su hijo en brazos.

Naturalmente hay que esperar a la publicación definitiva de las excavaciones para poder opinar sobre él, para nosotros, interesantísimo yacimiento de La Algaida. No obstante, queremos dejar clara una cuestión. Es muy posible que el santuario estuviera dedicado originariamente a Astarté en su advocación marina, lo cual no impide que, bajo influencia cartaginesa, se hubiera dado allí también culto a Tanit, tal como parecen indicar los pebeteros, y quizá las figuras curótrofas. Las excavaciones del templo de Sarepta por Pritchard, así como otros testimonios del área púnica (véase más abajo...), nos demuestra que ambas diosas pueden haber recibido culto conjuntamente. En este mismo sentido, cabe aquí recordar el famoso texto de Plinio (IV, 120), en que hace referencia a los diversos nombres recibidos por la isla Eritía, donde estuvo el más antiguo asiento de la ciudad de Cádiz. Dice Plinio que Timeo y Sileno la llamaban Aphrodisias, y los indígenas insula Iunonis, lo que parece aludir a una correspondencia Astarté-Tanit (MARÍN CEBALLOS, 1983, 16).

\section{FIGURAS FEMENINAS CURÓTROFAS}

Se trata de varios ejemplares de figurillas femeninas de terracota, entronizadas y amamantando a un niño, aparecidas en el ámbito ibérico. Dos de ellas, idénticas, proceden de la necrópolis de Cabecico del Tesoro (Verdolay, Murcia). La tercera, de La Albufereta (Alicante). La cuarta, más cuestionable, procede de la llamada necrópolis ibérica de Orán, cuyos materiales se conservan en el MAN.

Las figuras de Verdolay (láms. 11 y 12), actualmente en el Museo de Murcia, representan a una mujer sentada en trono de amplio respaldo, redondeado en su parte superior y ligeramente vuelto sobre su cabeza a manera de dosel. Se peina con cabello ceñido en torno a la frente, cayéndole a ambos lados del rostro dos trenzas o tirabuzones que 

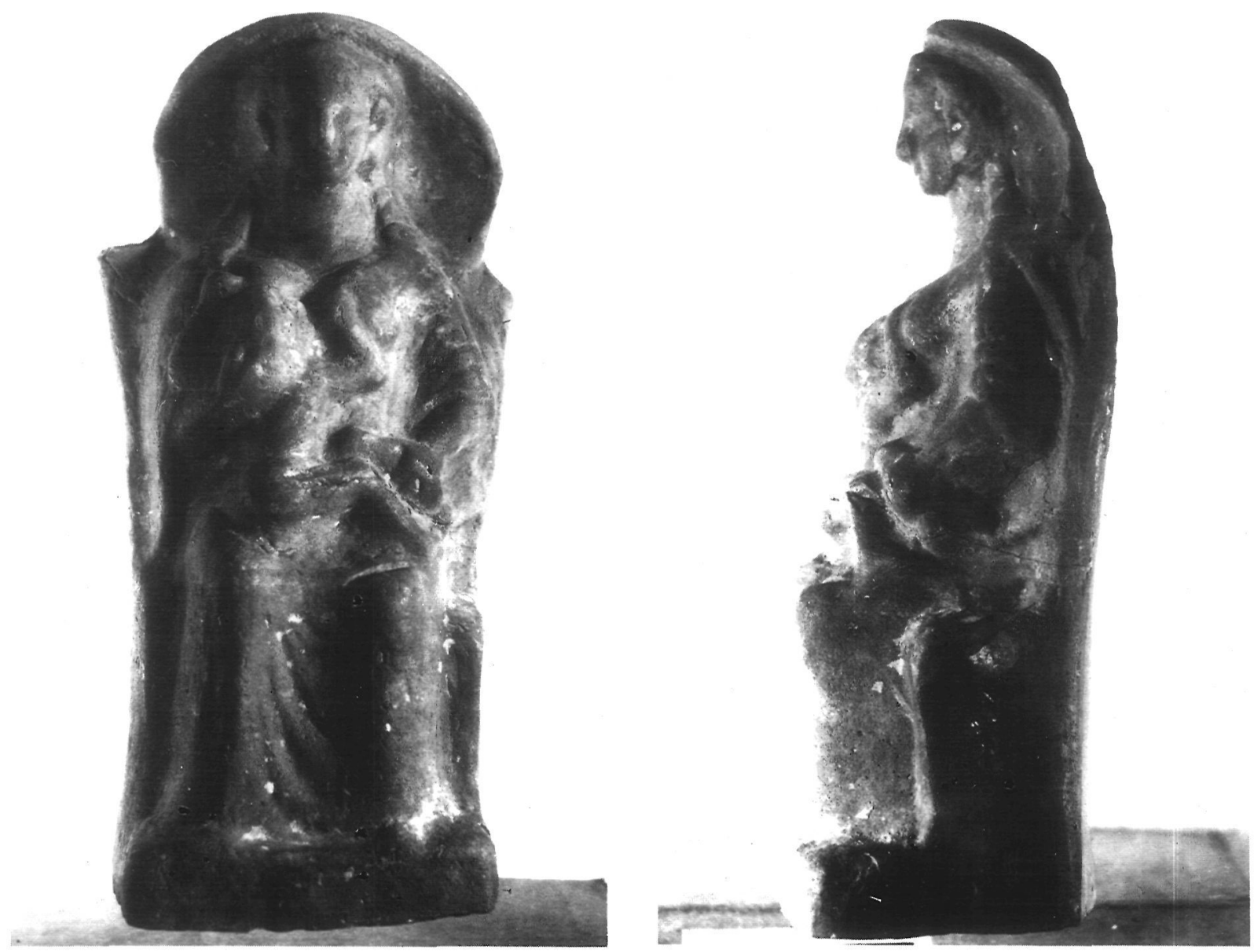

Lám. 11-12.-Figura de la necrópolis de Cabecico del Tesoro, Verdolay, Murcia (foto Museo Provincial de Murcia).

llegan hasta los hombros, y sobre el mismo un velo que se deja ver por detrás. El rostro presenta rasgos exóticos, resaltados por los ojos y las prominentes orejas que quedan por fuera del cabello, de un modo bien conocido en la tradición figutativa púnica (MOSCATI, 1975 b, figs. 163, 164, 184). Se viste con túnica talar, y mangas hasta el codo. En sus brazos, sostiene un niño que se sienta sobre su falda, girando el torso hacia el pecho de la madre, que le sujeta la cabeza con su mano izquierda y las piernas con la derecha. El niño levanta ambos brazos sobre el busto materno. Todo el conjunto se asienta sobre una leve peana (NIETO, 1943-44, 156, lám. 4; FERNÁNDEZ FUSTER, 1947, 59-60; ASTRUC, 1962, 73).

Los dos ejemplares de este mismo molde aparecieron, como se ha indicado, en sendas tumbas de la necrópolis de Cabecico del Tesoro, junto a la urna. En opinión de G. Nieto, podrían fecharse en la segunda etapa de la misma, a partir de fines del siglo III, hasta la presencia romana (NIETO, 1943$4,173)$. No obstante, ha de advertirse de cierta imprecisión en las dataciones de Nieto, a causa de no haberse concluido nunca el estudio de la necrópolis.

La pieza de La Albufereta presenta en cambio rasgos mucho más helenizantes (lám. 13). Mide 21 cms. de altura. La figura femenina se sienta en un trono de gran respaldo que, también en este caso, se vuelve ligeramente hacia la cabeza de la diosa (14). El peinado, apenas apreciable por lo gastado del molde, recuerda al de la Hygeia de Tegea, de mediados del siglo IV. El rostro presenta los ras-

(14) No encontramos paralelos exactos para el trono, que parece seguir modelos helenísticos, pero en una interpretación local. Guarda cierta semejanza con el representado en una terracotta de Mirina, en el Louvre (RICHTER, 1966, Lám. 143). 


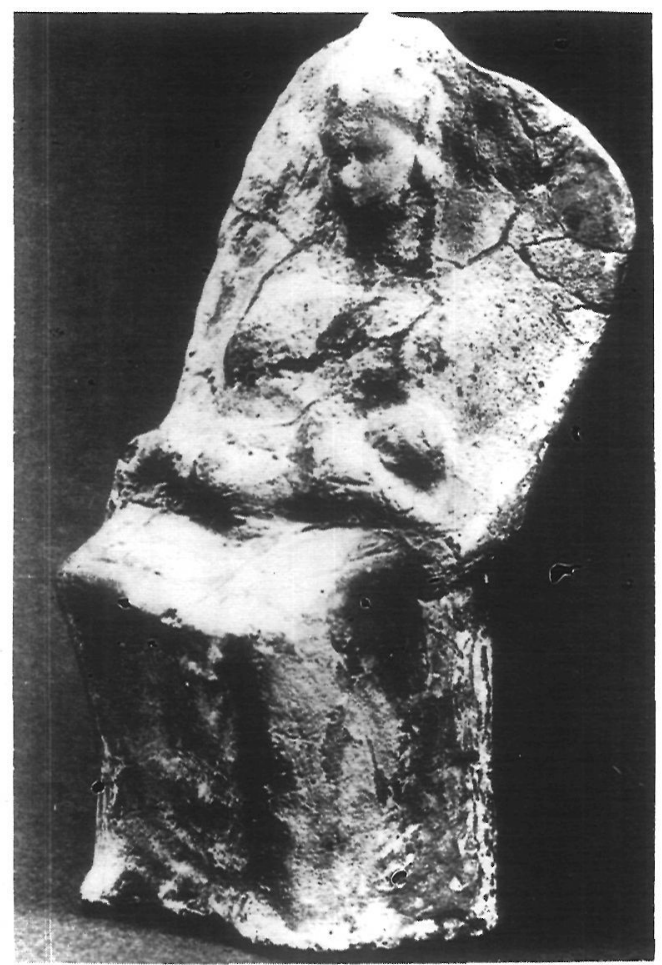

Lám. 13.-Figura de la necrópolis de La Albufereta

gos idealizados propios del siglo IV griego. De forma especial sería emparentable con la cabeza de Ampurias en el Museo Arqueológico de Barcelona (RIPOLL, 1969, lám. IX). Presenta la mirada baja, dirigiéndola sin duda hacia el niño que tiene en los brazos. Éste, sobre la falda, reclina la cebecita en su brazo derecho y levanta el izquierdo hacia el pecho de la madre (LAFUENTE, 1934, lám. X; TARRADELL, 1968, fig. 123; LLOBREGAT, 1972, fig. 16, 1974, p. 302, lám. V. ASTRUC, 1962, 73. BLÁZQUEZ, 1975, 79). El tipo es bien conocido en el arte griego, especialmente en el Artemision de Éfeso, aunque con notables diferencias de estilo. Aquéllas presentan al niño en la misma posición, pero éste levanta hacia el pecho de la madre la mano derecha (HIGGINS, 1954, 551 ss.).

Tan importante o más que la figura en sí, es su contexto. Apareció en la que Lafuente llamara «gran sepultura ritual» de la necrópolis de La Albufereta, recientemente revisada por F. Rubio Gomís (RUBIO, 1986, 214-226). Se trata de un gran túmulo que contenía varios enterramientos, el más importante de los cuales es el L-127-A. A un lado había una especie de «hornillo», hecho con adobes, for-

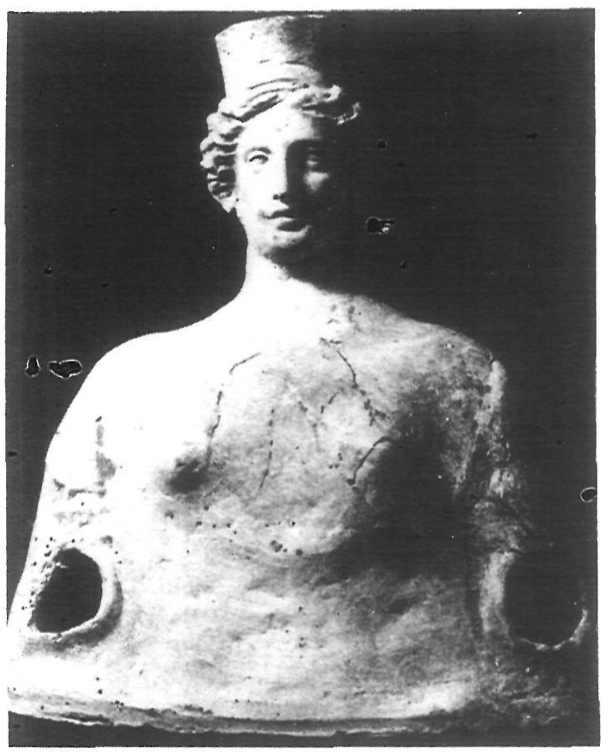

Lám. 14.-Busto de terracota de la necrópolis de La Albufereta, Alicante.

mando dos filas separadas unos $20 \mathrm{cms}$. En la parte opuesta, una gran piedra de forma cónica de unos $120 \mathrm{cms}$. de altura. El ajuar era copiosísimo, predominando las piezas de terracota de claro matiz púnico: tres pebeteros en forma de cabeza femenina, un gran busto femenino de tipo ibicenco, del que nos ocuparemos más adelante, la pieza aquí estudiada y otras cuatro figuras femeninas representando a mujeres, en posición estante, con amplios vestidos. Una de éstas, con el número de registro NA-6004, L., «parece estar en estado de embarazo», según estimación de F. Rubio, y sostiene una paloma en su mano derecha (ibidem, 215, fig. 97). En la misma tumba y también en terracota, una pequeña cueva con orificios que quizá sirvieran para colocar velitas o antorchas (RUBIO, 1986, 216; TARRADELL, 1973, 35-37), amén de otros fragmentos de figuras y numerosas piezas de metal y cerámica.

El gran busto citado (lám. 1) representa a una diosa tocada con alto kalathos del que sólo se conserva la cabeza y parte del pecho y lado izquierdos, encontrándose restaurado y construido en el Museo de la Diputación de Alicante. Mide $47 \mathrm{cms}$. de altura. De forma un tanto acampanada, la espalda es lisa, mientras el pecho femenino está ligeramente indicado. Dos grandes orificios a ambos lados servirían para asomar los brazos móviles. El rostro es de rasgos perfectos, muy helénicos. Se peina con raya en medio y el cabello enmarcándole el rostro, 


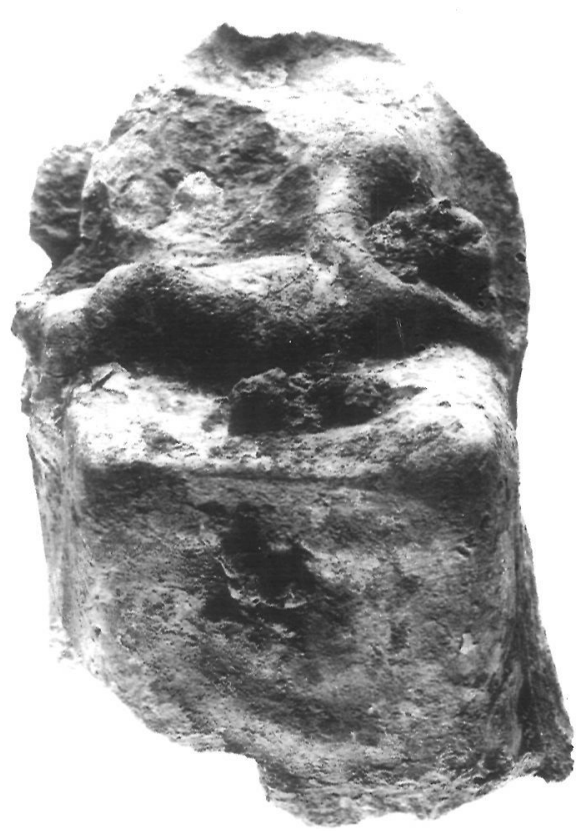

Lám. 15.-Figura entronizada de la supuesta «necrópolis ibérica de Orán», (foto MAN).

con las puntas vueltas hacia arriba, enrollándose en una diadema lisa que asoma en su parte superior. Es totalmente hueca, y sin tapa en la zona del kalathos. Presenta restos de policromía (RUBIO, 1986, 218, n. ${ }^{\circ}$ R. NA 5995, Ref. L, fig. 97; ASTRUC, 1962, 74; LLOBREGAT, 1974, 303, lám. VI).

Se trata evidentemente de un busto, cuyo prototipo hay que buscar en los utilizados como exvoto en los thesmophoria sicilianos, que luego pasan a Ibiza y Cartaga (ALMAGRO, M. J., 1980 b, láms. LI-LXIII), donde son muy frecuentes, sobre todo en las tumbas. Muy probablemente éste procede de Ibiza (ASTRUC, 1962, 74), y no nos cabe duda de su significación en el contexto de la tumba; como los pebeteros, la figura entronizada y quizá alguna de las terracotas femeninas, representa a la diosa Tanit, y todo este conjunto constituye una prueba de la devoción a la diosa por parte de la persona allí enterrada.

Una cuarta representación de diosa entronizada nutricia sería la procedente de la necrópolis ibérica de Orán, que se conserva en el MAN (SANTOS, 1983, fig. 144). (Lám. 15). En su estado actual la falta de cabeza y la base. Mide de altura máxima $12,50 \mathrm{cms} ., 9,70$ de anchura y 8 de profundidad. Representa a una gruesa mujer que se sienta sobre un sillón sin brazos, cuyo respaldo parece redondeado en su parte superior. Las piernas se alargan bastante hasta la altura de las rodillas, de las que la izquierda queda algo más adelantada. No pueden apreciarse detalles del vestido por tratarse de un molde muy gastado. El niño es bastante grande, y se halla tendido sobre la falda de la madre, llevando su mano al pecho izquierdo de ésta. Falta también el brazo derecho de la misma, cuya mano parece sujetar los pies del niño. La figura está totalmente hueca, y tiene un gran orificio en la parte posterior.

Además de los pebeteros ya mencionados (véase supra), en esta misma necrópolis apareció otra figurita estante que parece llevar algo, posiblemente un niño, en los brazos, semejante a algunas de la necrópolis de La Albufereta (SANTOS, 1983, lám. II, 6).

Todo parece indicar pues que hay que interpretar estas figuras como divinidades nutricias. Anótese que todas ellas proceden de necrópolis en que aparecen otros elementos de influencia púnica, en especial los pebeteros. Hace años que M. Astruc apuntaba que estos materiales eran producto de un mismo culto, probablemente muy sincrético, y que se debían a la presencia cartaginesa en Levante (ASTRUC, 1962, 72-76). El tipo de figura femenina entronizada amamantando a un niño, es muy viejo en el Mediterráneo, pero la iconografía aquí estudiada la encontramos en el mundo griego: así en Beocia (fines del siglo VI y durante el V) (HIGGINS, 1954, 793-820), y especialmente en Rodas (desde comienzos del s. V) (HIGGINS, 1954, 133: ZUNTZ, 1971, 111) y la costa Jonia (Artemision de Éfeso, HIGGINS, 1954, 551 ss.), desde donde se difunde por la Magna Grecia y Sicilia: en los santuarios de Hera en Poseidonia (LÉVÉQUE, 1973, 50; 1961, 216), y Fundo Patturelli, en Capua (LÉVÉQUE, 1973, 52); necrópolis de Selinunte, junto al santuario de la Malophoros (LÉVÉQUE, 1973, 51), en Bitalemi y Monte Bubbonia, al N. de Gela (ZUNTZ, 1971, 112, 93; ORLANDINI, 1966, láms. IX, XI y XIX). C. Kurtz y J. Boardman han hecho notar que estas terracotas son comparativamente raras como ofrendas funerarias. Advierten, además, que los tipos son iguales, tanto si se les encuentra en santuarios como en tumbas (KURTZ Y BOARDMAN, 1971, 209). Es sin duda a través de Sicilia como pasan al mundo púnico.

Las terracotas representando a una diosa entronizada son muy frecuentes en Ibiza, tanto en necrópolis, donde M. J. Almagro las interpreta como figuraciones de Tanit (ALMAGRO, M. J., 1967, 28 ss., 1980 (2), láms. XLII-XLIV, ns. 64-68, 76-79), 
como en santuarios (AUBET, 1982, lám. XX, ns. $1-3,27)$, sin embargo, es digno de notar que no conocemos ningún ejemplar en que tales figuras amamanten a un niño. Ello nos obliga a pensar, por un lado, que nuestras terracotas no proceden de allí, y por otro, que existe una preferencia peninsular por estas diosas nutricias. Hace años comentábamos la presencia en una tumba ibérica del siglo $\mathrm{V}$ de la famosa Astarté de Galera, en la que se resalta de una manera muy singular su capacidad nutricia, así como el carácter sagrado y sobrenatural de tal alimento, siguiendo la pauta marcada por viejas divinidades orientales como Isis en Egipto o Anat en Ugarit (MARÍN CEBALLOS, 1978, 28-30).

Un trabajo de C. Picard (PICARD, 1969, 474484, láms. CLXX-CLXXIV), resulta de un enorme interés para ambientar estas terracotas. A propósito del artículo de M. Rénard sobre el culto a la Nutrix Saturni en el África romana, en que remarca que Nutrix es una de las formas romanas herederas de la púnica Tanit (RÉNARD, 1959, 27 ss.), recoge dicha autora los testimonios de esta Tanit madre, Tanit curótrofa y nutricia. En su opinión, dicho concepto, estrictamente púnico, se reviste de formas tomadas del mundo egipcio (Isis) y del griego (Demeter-Kore). Así, encontramos diversas representaciones, sobre todo en navajas de afeitar rituales, y en gemas, de una Isis amamantando a Horus niño, que presenta a veces rasgos no egipcios, más próximos a Tanit (PICARD, 1969, figs. 1 y 3, lám. CLXX; PICARD, 1965-6, n. ํ 25, fig. 58, lám. XXIII, n. ${ }^{\circ} 34$, fig. 63 , lám. 28). Igualmente, hay otras en que la vemos como diosa entronizada a la griega, amamantando a veces a un niño (15), aunque imágenes de este tipo son más frecuentes ya en la Cartago romana, representándose en este caso más bien a Nutrix (16).

(15) Así la «estatua Cintas», recompuesta por él, que se fecha aproximadamente en el 200 a. de C., muestra a la diosa velada, como una dama griega, y en su espalda se ha tallado una especie de nicho en que figura una diosa con un niño, alusión al aspecto maternal de la «Gran Dama» de Cártago (CINTAS, 1952, 17 ss.; RÉNARD, 1959, 39, pl. III, 7). También, la imagen grabada sobre un pendiente de la necrópolis de Sta. Mónica, que representa a una dama entronizada y velada con un niño sobre la falda y en la parte superior, como símbolos de divinidad, la estrella y el creciente (PICARD, 1969, 477, lám. CLXXIII, fig. 7 , s. III).

(16) Así, por ejemplo, la figura de terracotta de tamaño próximo al natural, aparecida en el llamado santuario de Baal y Tanit de Bir Bou Rekba, ceca de Siagu, que publicara Merlín. Se trata
Este carácter maternal de Tanit, se atestigua también en la epigrafía, siendo calificada de madre en dos inscripciones (RÉNARD, 1959, 37; PICARD, 1954, 65; GSELL, 1924, 247 y 260; HVIDBERGHANSEN, 1979, I, 20-21 y notas).

Respecto a la relación de Tanit con Isis, son varios los autores que se han ocupado de la misma. Culican, en especial (CULICAN, 1968, 69 ss.), observa cómo ya en Fenicia existe una estrecha identidad entre Isis y Astarté, que se patentiza en una adoración por el icono de Isis amamantando a Horus, tanto en estatuillas como escarabeos, abundando especialmente estos últimos en el Mediterráneo Occidental. En un caso (LIDZBARSKI, 169), encontramos una inscripción dedicatoria a Astarté al pie de una de estas estatuillas. En otro (CLERMONT-GANNEAU), una dedicación conjunta a Isis y Ashtart. En cuanto a los escarabeos, lo que marca su carácter fenicio es la presencia del thymiaterion ante la imagen divina. En la propia Península tenemos un escarabeo en piedra negra, aparecido recientemente en las excavaciones del «santuario» de Zalamea de la Serena, Badajoz (MALUQUER, 1981, 126, fig. 54). En él vemos a la diosa Isis sentada y amamantando a Horus niño. Delante, el característico thymiaterion, y sobre la cabeza de la diosa, un disco. También son frecuentes escarabeos de este tipo en Ibiza (HERNÁNDEZ Y PADRÓ, 1982, 28-46, 233).

Como se ha visto, tal relación e identidad continúa luego, en Cartago, entre Isis y Tanit (CULICAN, 1968, 72 ss.). El tema ha sido estudiado recientemente por M. ${ }^{a}$ E. Aubet (AUBET, 1976, 6182), quien documenta la amplia adopción de la falda o manto «de alas» isíaco para representar a Tanit. Asegura ésta que el tipo alado de Tanit parece generalizarse en Cartago a partir del siglo IV, iniciándose entonces varias fases de esquematización que abocarán en la formación de las figuras acampanadas de Es Cuieram, en Ibiza, apuntando incluso la posibilidad de que el tipo se hubiese iniciado ya en época anterior, por lo menos el siglo V. Un ejemplo excepcional es el famoso sarcófago mal llamado de «la sacerdotisa», en la necrópolis des Rabs o

de ur santuario de época romana que se considera prueba de la fuerte persistencia de la religión púnica en esta época (MERLÍN, $1910,48-9$, lám. IV). Todos estos testimonios, junto con las inscripciones que hacen referencia a Nutrix, son catalogados por RÉNARD (1959, 27-52). 
Sainte Monique, en el que se mezclan influencias griegas y egipcias. En su opinión, estas grandes alas pueden representarse de tres modos distintos 1) como manto, cuando la figura es un busto, 2) como alas que parten de la cintura y se cruzan sobre el cuerpo, 3) superponiéndose en varias capas sucesivas hasta alcanzar los pies.

Sin embargo, para M. ${ }^{a}$ E. Aubet, esta influencia isíaca sobre Tanit es puramente formal, externa, sin que se pueda hablar de un «sincretismo», como tampoco puede decirse que éste se dé con Demeter o Kore, pese a adoptarse también su iconografía (ibidem, 79). Es éste un tema en el que es imposible afirmar nada de modo rotundo, ante la ausencia de testimonios epigráficos y literarios, pero sobre el que habría que investigar a fondo. Dadas las estrechas relaciones que hemos venido siguiendo desde Fenicia entre ambas diosas, resulta difícil creer que no existe más que una mera influencia formal, máxime cuando éstas coinciden en su aspecto nutricio y de protección de ultratumba.

Además de las figuras entronizadas, existen en el mundo ibérico otras representaciones de madre con niño, en ambientes religiosos o funerarios, que creemos relacionadas, conceptualmente hablando, con éstas. En primer lugar, una serie de terracotas que figuran a una mujer de pie, con largo vestido y generalmente veladas, y un niño sobre su brazo izquierdo. Una de ellas procede de una tumba del Valle de Abdalaxis, Málaga, actualmente en el Museo Arqueológico de Sevilla. Mide $18 \mathrm{cms}$. de altura. La mujer, en posición estante, se envuelve en un manto que le cubre la cabeza y la espalda, recogiéndose luego a su lado izquierdo. Sobre su brazo izquierdo sostiene un niño, que aparece erguido y en posición frontal. Éste parece llevar algo en su mano derecha, que no puede apreciarse. La superficie posterior es lisa (GARCÍA Y BELLIDO, 1958, 194-5, fig. 6. BLÁZQUEZ, 1975, 79 y 91). Otra pieza, muy semejante, procede del santuario de Castellar de Santisteban, actualmente en el Museo de Jaén. En actitud similar a la anterior, deja asomar por debajo del manto un peinado de rizos que le enmarca el rostro, con dos mechones, a manera de tirabuzones, cayéndole a ambos lados. El manto le cae por la espalda, sin cubrirle los hombros, llegándole hasta los pies y recogiéndose delante, bajo la cintura. El niño se yergue en postura muy similar al anterior, y parece igualmente sujetar algo con su brazo derecho. Recientemente han aparecido varias terracotas de este tipo, al parecer del mismo

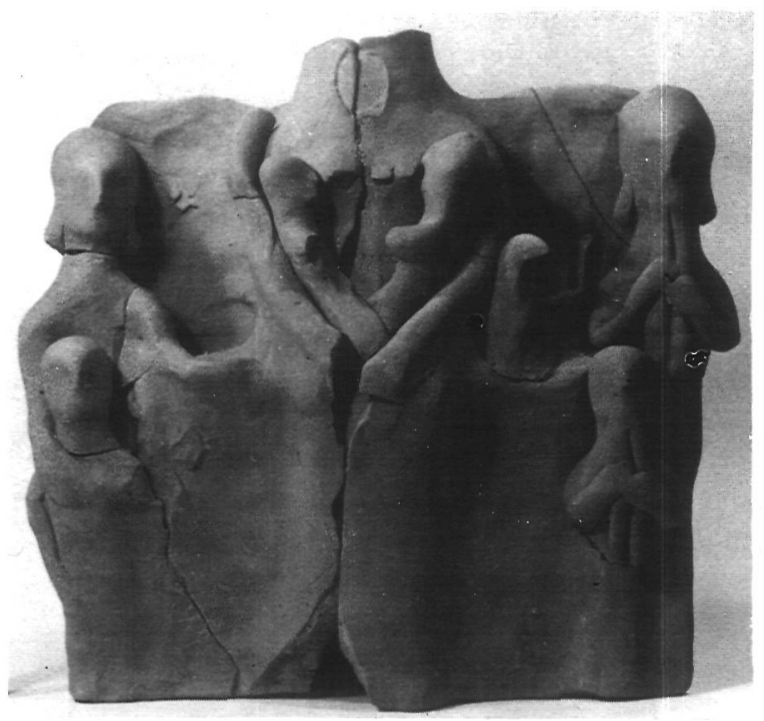

Lám. 16.-Pinax del poblado de La Serreta (Alcoy, Alicante). (Foto Museo de Alcoy).

molde que la de Castellar, en el santuario de La Algaida, noticia que debemos a la amabilidad de $\mathbf{R}$. Corzo.

Versión mucho más torpe y «local» de estos tipos de madre con niño sería la procedente de la necrópolis de La Albufereta, concretamente de la tumba n. ${ }^{\circ} 100$, en el Museo de la Diputación de Alicante (FIGUERAS, 1946, 315-16, fig. 1 d; NICOLINI, 1973, 46, fíg. 21. BLÁZQUEZ, 1975, 79 у 91, RUBIO, 1986, 99, n. ${ }^{\circ}$ R. NA-6008, ref. F-271, fig. 39). Mide $28 \mathrm{cms}$. de altura. La figura se presenta igualmente de pie, vestida con larga y amplia túnica de pliegues sobre la que se superpone un manto que parte de la alta tiara cónica. En su mano derecha sostiene una paloma, y en el brazo izquierdo un niño pequeño inclinado sobre el pecho de la madre. El modelado es muy sumario, y parece haber estado policromada (17). De otra tumba de la misma necrópolis (la llamada «gran sepultura ritual»), procede otra figura, igualmente estante, a la que le falta la cabeza y parte de la falda. Alarga sus brazos al frente, ofreciendo en la mano derecha una paloma. De ella dice Rubio Gomís que parece estar embara-

(17) La tumba n. 100 se fecha en el siglo IV (RUBIO, 1986, 116). En la misma apareció un pebetero y el famoso grupo relivario de la Albufereta, hoy perdido. 


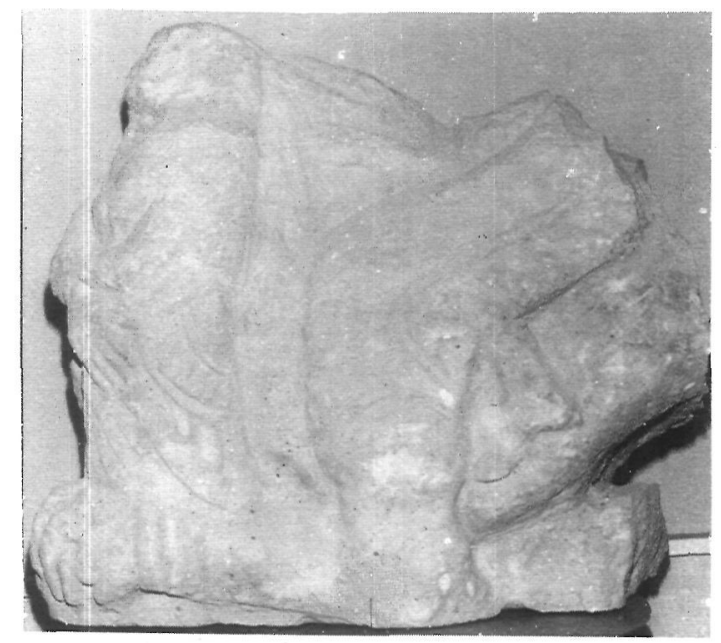

Lám. 17.-Esfinge del Parque Infantil de Tráfico de Elche (foto Museo Municipal de Elche).

zada (RUBIO, 1986, 199, NA-6004, LAFUENTE, 1934, 28-29, lám. X) (18).

No nos cabe la menor duda de que todas estas figuras tienen que ver con la escena representada en el pinax de terracota hallado en el poblado de La Serreta, actualmente en el Museo de Alcoy (lám. 16). De muy tosca ejecución, en el centro y sobresaliendo de la forma casi cuadrada de la placa del fondo, se advierte un grueso cuello correspondiente a la figura acéfala que domina la escena. Se trata a todas luces de una mujer, vestida al parecer con larga túnica y probablemente sentada, cuyos brazos sostienen a dos niños de pecho que aproximan sus bocas a los de la madre, los cuales, por cierto, dan la sensación de ser múltiples, aunque ello puede deberse a la tosquedad de la ejecución. Al lado derecho del pinax, un grupo constituido por otra figura femenina, de pie y en actitud frontal, y ante ella un niño que le llega a la altura del pecho y sobre el que se posa su brazo derecho. La mano izquierda parece dirigirse hacia la imagen central, y probablemente sostendría una paloma como la que aparece al otro lado de la misma. El otro grupo es similar, con la diferencia de que madre e hijo se presentan en actitud de estar

(18) Resulta de interés relacionar estas figuras estantes curótrofas con la aparecida en una tumba de la necrópolis romana de Almuñécar, junto con otras terracottas, fechable en el primer cuarto del sigo II d. C. (RUIZ Y MOLINA, 1982, 328,-9, 344 , fig. 11 y lám. 52 a), que podría interpretarse como pervivencia de estos cultos.

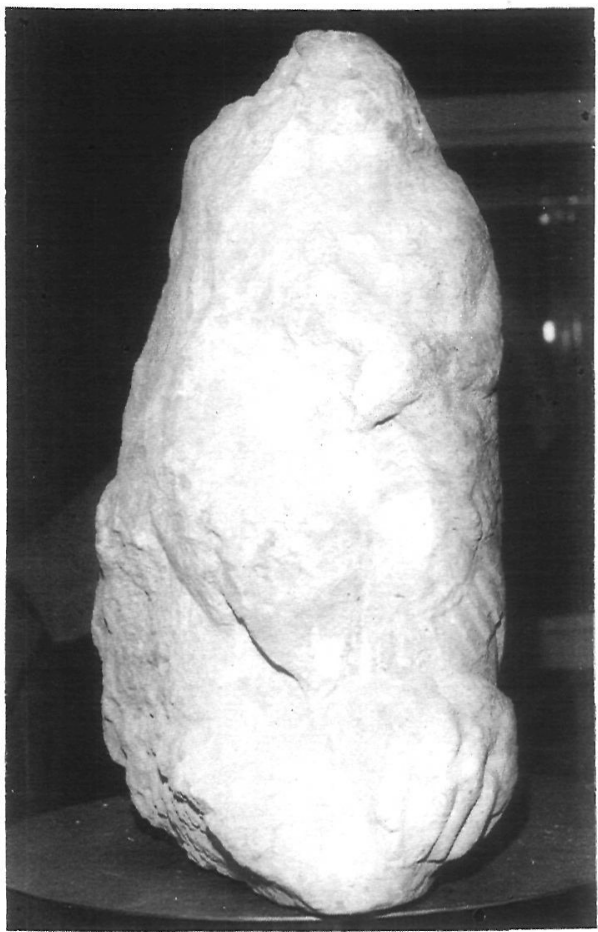

Lám. 18.-Esfinge del Parque Infantil de Tráfico de Elche (foto Museo Municipal de Elche).

tocando una doble flauta, y entre ellas y el personaje central aparece una paloma. La ejecución general es muy tosca, los rostros se representan simplemente a base de pellizcos que dan forma a la nariz, con un ligero rehundimiento para los ojos (TARRADELL, 1968, fig. 64; LLOBREGAT, 1972, 57, lám. XV; BLÁZQUEZ, 1975, 79).

Es evidente que tenemos aquí, toscamente representada, una diosa madre de tipo mediterráneo, cuyo rasgo más característico es su aspecto nutricio, y a la que acuden las madres con sus hijos en demanda de protección, con un ritual de música y ofrendas como la paloma. Esta diosa debe ser la misma a la que se ofrecen esas figuras de las tumbas con palomas y niños, ya que la divinidad nutricia de la fecundidad es también la que protege en el trance de la muerte, según un concepto primario de la fenomenología religiosa. Nos vienen a la mente los viejos santuarios de la costa Sur y Occidental de Italia, especialmente el de Fundo Patturelli, en Capua, con millares de exvotos de terracota representando a madres con uno o muchos hijos, y 150 estatuas que representan a la divinidad dando el pecho a varios niños. Esta diosa será identificada 

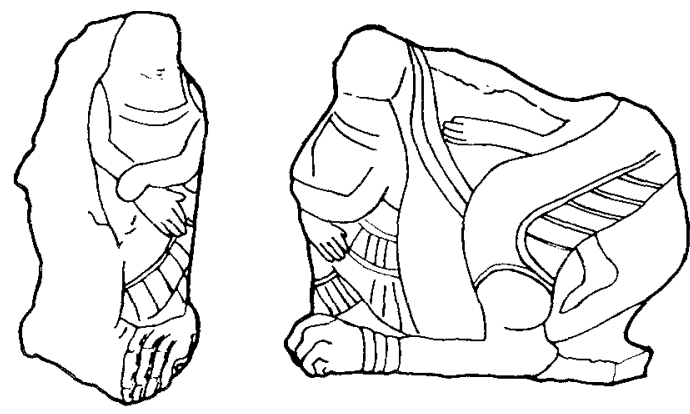

Fig. 4.-Esfinge del Parque Infantil de Tráfico de Elche, según Teresa Chapa.

a la Hera de Poseidonia, pero sin duda se trata de una deidad indígena (LÉVÊQUE, 1973, 52; SESTIERI, 1955, n. ${ }^{\circ} 3,149$ ss.).

Todo este ritual tiene un intenso aroma mediterráneo que nos lleva hasta Serepta, en la costa fenicia.

\section{LA ESFINGE Y OTROS TESTIMONIOS ILICITANOS}

Se trata de una escultura en forma de esfinge (láms. 17 y 18; fig. 4) aparecida en el año 1972 en el área del Parque Infantil de Tráfico de Elche, en excavaciones realizadas por A. Ramos Folqués y su hijo R. Ramos Fernández, junto con otros restos escultóricos ibéricos, en medio de un contexto al parecer correspondiente a un horno romano que se contruyó sobre una plataforma hecha de detritus de una necrópolis ibérica. El único material fechable parece ser una crátera de columnas del siglo IV (RAMOS Y RAMOS, 1976, 671-700).

Trabajada sobre un bloque rectangular de piedra caliza que mide $69,5 \mathrm{cms}$. de largo por 65 de alto y 28 de grueso, está tallada sólo por su lado izquierdo y parte del frente. El efecto general que causa es de un cuerpo excesivamente largo, desproporcionado. El relieve es bastante plano. Está echada sobre sus patas que terminan en grandes garras, como extrañas manos con cinco dedos y dos acanaladuras a manera de pulseras. Bajo el arco formado por la parte posterior del cuerpo se ha ahuecado la piedra toscamente, y por ese hueco asoma el rabo, introducido por detrás, entre las piernas.

De la esfinge se aprecia el arranque del ala, dividida en dos cuerpos superpuestos de los que el segundo muestra una esquemática representación de plumas paralelas. Montada sobre la misma, se ve una figura delgada y pequeña de la que sólo queda una mano, en ligero relieve sobre el cuello del animal, y una pierna y pie, al parecer descalzo, que asoman por debajo del ala. El cuerpo de la misma queda en su mayor parte bajo ésta, y su cabeza y parte superior han desaparecido. Parece llevar la mano a dos acanaladuras en relieve que podrían ser una especia de trenzas.

En la parte anterior de la esfinge se muestra una figura femenina. No ocupa posición totalmente frontal, sino un poco esquinada hacia su lado derecho, el único trabajado del bloque. Parece estar de pie sobre la garra inferior de la esfinge, no apreciándose los pies. La cabeza está muy deteriorada. El vestido es un tanto extraño. Lleva una especie de manto de alas cuyos pliegues le salen de la parte baja de la espalda, llegando hasta el suelo. A una primera fila de plumones se superpone otra en la que éstos son más cortos y apretados. El cruce de las alas queda un poco ladeado a la derecha, al parecer por la posición esquinada de la figura.

En la parte superior del pecho, entre los brazos, el vestido lleva un detalle muy significativo: una especie de flor trilobulada. Los brazos se cruzan a la altura de las muñecas, muy torpemente trazados, en especial el derecho. La mano izquierda no se ha conservado. La derecha resulta enormemente desproporcionada. En la cabeza se advierte un orificio irregular, seguramente por la acción del pico. El rostro, ligeramente levantado hacia arriba. El cuerpo de la esfinge está partido en su parte central, faltando toda la parte superior del jinete. Se conserva mejor la parte posterior de la misma (CHAPA, 1980, 315-17).

Para Teresa Chapa, la esfinge sigue modelos griegos, no sólo en su forma exterior, sino también en el concepto de animal de aspecto tranquilo, en todo caso neutral, que se muestra en las representaciones cerámicas y escultóricas ya desde los siglos VI y V, puesto que en la época anterior lo hacía como un ser terrorífico y amenazador para el hombre, sobre el que se abalanzaba para arrebatarle a la otra vida. En efecto, según $\mathrm{H}$. Walter, a quien sigue Chapa (WALTER, 1960, 67-68), este carácter hostil para el hombre lo va perdiendo la esfinge con el tiempo, y aunque mantiene su relación con la muerte, parece que realiza esta función demoníaca de un modo más «suave», lo que permite su representación como guardián de tumbas, ser benéfico por tanto, en las estelas, función en la que la encontramos también en el ámbito ibérico (CHAPA, 1980, 331-2; ALMAGRO GORBEA, M., 1983, 7 
ss.). Hay alguna representación, como son los fragmentos de Atenas y Siracusa (figs. 27 y 30 de Walter), y especialmente este último, en que da la impresión de que realmente la esfinge transporta al moribundo, pero incluso en estos casos no se puede negar el carácter hostil del animal; así en el fragmento de Siracusa huyen de él los compañeros del muerto. Por otro lado, la figura humana aparece debajo de la esfinge, aunque agarrada al cuerpo de ésta en el fragmento de Siracusa, y en otros casos en el suelo, lo que remarca ese carácter de animal victorioso sobre el moribundo patente en otras imágenes (figs. 19, 27, 28 y 29 de Walter). En cambio, en la esfinge de Elche este carácter hostil no existe, y el animal transporta al muerto sobre su lomo, de forma similar al grupo escultórico procedente de Estepa, en el Museo Arqueológico de Sevilla, en que un león lleva una figura masculina, al parecer un guerrero, sobre su grupa (CHAPA, 1980 b, 609-612, lám. CXXI A 2, fig. 4.126, cat. SE 8).

Pero lo más interesante para nuestro objetivo del bloque escultórico estudiado es la figura femenina representada en la parte delantera de la esfinge. Como hemos visto, se cubre con el manto de alas que en este caso se pliegan y cruzan sobre la falda. No cabe duda de la procedencia cartaginesa de este atavío, que encontramos en la famosa «sacerdotisa» de Cartago, del Museo Lavigerie, excelente talla sobre la cubierta de un sarcófago, que ya hace años fue interpretada como Tanit por G. Charles Picard (PICARD, 1954, 66 ss.). Pero gracias al excelente trabajo de M. A. Aubet (AUBET, 1976, 61 ss.), podemos estar seguros de que tal iconografía corresponde a esta diosa, lo mismo que en el caso de las figuras acampanadas de la cueva de Es Cuieram, en Ibiza (AUBET, 1976, 64 ss.; 1982, 60 ss.). Otro detalle que nos hace evocar tales figuras es la flor trilobulada sobre el pecho, idéntica a la que observamos en estas figuras ibicencas (AUBET, 1982, lám. XII, tipo 12 , lám. XIII, tipo 15, tipo 16, lám. XIV, tipo 17, tipo 18, tipo 19).

Por todo lo antedicho, creemos que también aquí se ha representado a Tanit, y de esta forma se constataría su culto en Elche, así como su carácter funerario. Es evidente que en este caso actúa como guía y conductora en el camino de la esfinge y su montura hacia el más allá, por tanto como divinidad sicopompa. Esta interpretación obligaría a rebajar la fecha asignada a la escultura por T. Chapa: fines del siglo VI o comienzos del V (CHAPA, 1980), pues Tanit tiene su esplendor a partir de fines

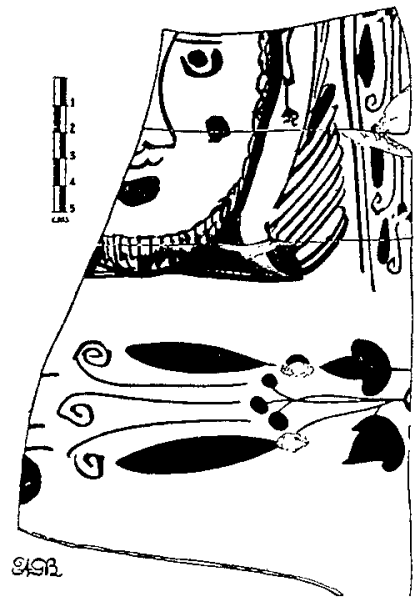

Fig. 5.- «Máscara» sobre un vaso ibérico de Elche. Según A. García y Bellido.

del V, y sobre todo durante el siglo IV, en especial con este manto de alas que en último término proviene de Isis, diosa que con sus alas protege al niño Horus, así como a los muertos en general, de ahí la frecuencia de su aparición en las tumbas egipcias. Creemos, pues, que difícilmente la esfinge puede ser fechada antes del siglo IV.

* * * *

Es interesante observar cómo este hallazgo ha venido a revalorizar una serie de testimonios sobre el culto a Tanit en la propia ciudad de Ilici. Uno de ellos, aunque tardío, es ese templo tetrástilo con la inscripción IUNONI que aparece en los sémises de ILICI de los años 13-12 a. de C. (VIVES, 1926, lám. CXXXIII, 4-5), cuya existencia real se corrobora por la inscripción de La Albufereta (CIL II, 3557) que menciona su restauración (BELTRÁN, 1953, 60). Es bien conocida la identificación entre

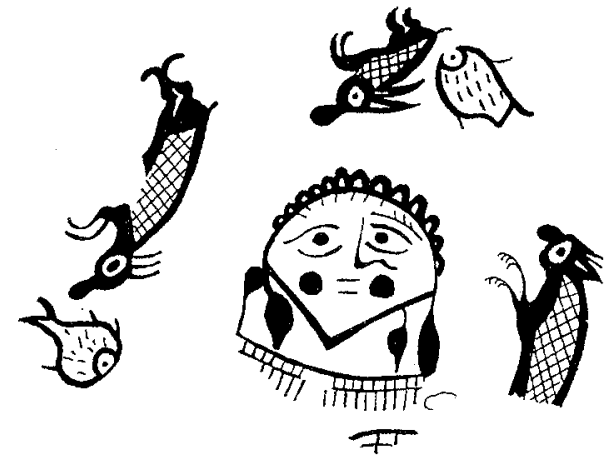

Fig. 6.- «Máscara sobre kernos ibérico de Elche, según A. Ramos. 


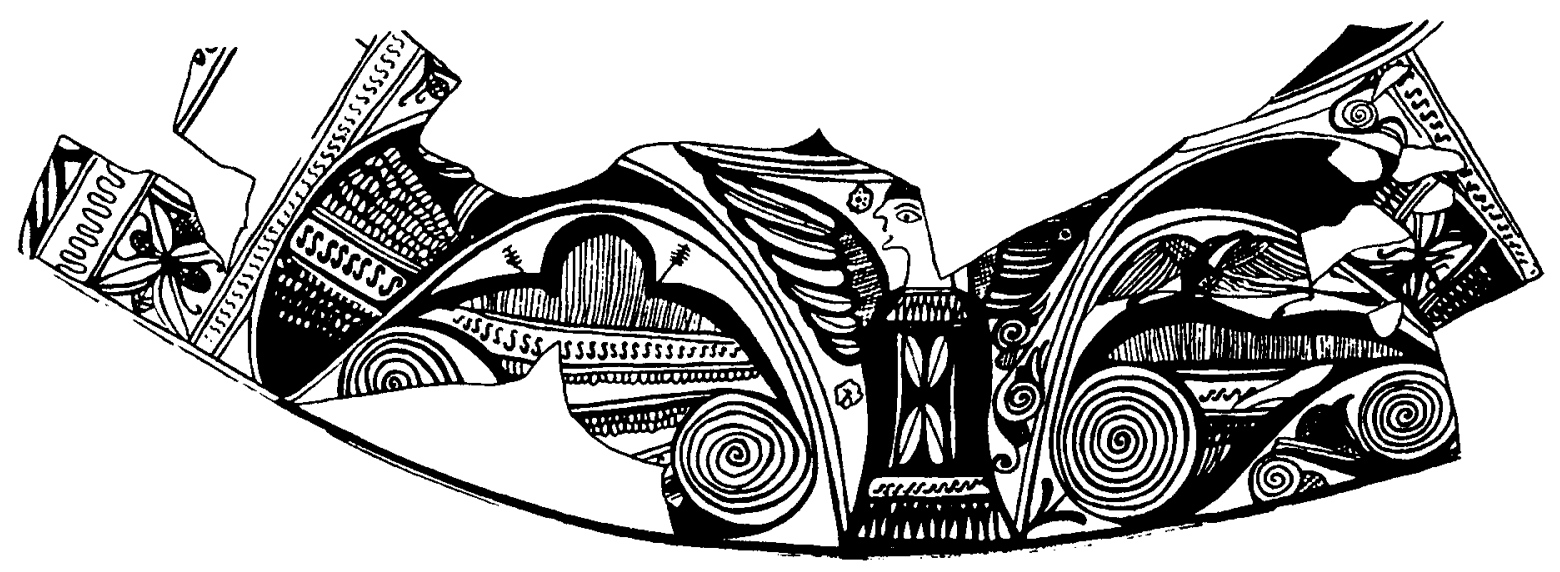

Fig. 7.-Dccoración figurada sobre un vaso ilicitano, según S. Nordström.

la diosa púnica y la Iuno romana que probablemente fue heredera suya en Ilici (PICARD, 1954, 101 ss., 108).

Pero además, contamos con la rica cerámica ilicitana de época ibérica. Tradicionalmente se ha venido reconociendo en las figuras femeninas allí representadas una impronta semita; hoy creemos poder afirmarlo. Entre estas imágenes femeninas pueden hacerse dos grupos: 1) las máscaras, 2) las figuras aladas.

El primer grupo ha sido objeto de estudio por A. Fernández de Avilés (FERNÁNDEZ AVILÉS, 1944, 161 ss.) y E. Kukahn (KUKAHN, 1962, 79 ss.; 1974, 113 ss.) (fig. 5), quien observó sus similitudes con los rostros o «máscaras» que aparecen en la cerámica pintada chipriota, y que se relacionan habitualmente con Astarté-Hathor. Distintivo de las mismas con los círculos rellenos en las mejillas, y a veces en la barbilla. Según Kukahn, tales máscaras se extienden al occidente púnico, donde las encontramos desde el siglo VI sobre huevos de avestruz, estudiadas por M. Astruc (ASTRUC, 1956, 29 ss.). Las estrechas similitudes con la cerámica chipriota llevaron a Kukahn a anticipar las fechas de la ilicitana, lo cual le ha sido refutado por S. Nordstrom, quien opina que tales contactos con Chipre debieron realizarse teniendo como intermediarios a Cartago o el Sur de la Península y que la cerámica ilicitana no puede fecharse con anterioridad al siglo II a. de C. (NORDSTROM, 1969, 210-211) (19). Estas másca-

(19) A. RAMOS FOLQUÉS sitúa esta cerámica en lo que denomina estrato b o Ibérico II, desde fines del siglo III hasta mediados el I a. de C. $(1976,17$ ss.) coincidiendo con él A. BLANCO $(1960,113)$. Recientemente R. RAMOS $(1982,121 \mathrm{ss.})$ se reafirma en esta misma idea de su padre. ras suelen situarse en lugares relevantes del vaso, así debajo de las asas, en el fondo del vaso, etc... A veces llevan alas. De especial interés nos parece la que se muestra en el fondo de un kernos, objeto de indudable uso religioso, rodeada de peces, liebres, aves y plantas (RAMOS Y RAMOS, 1976, lám. V, fig. 3) (fig. 6). La máscara de carácter sagrado tiene un origen indudablemente oriental, mesopotámico, de donde pasará al mundo fenicio-púnico y griego (BARNETT, 1960, 147 ss.; PICARD, 1965-6, 4055 y passim; CULICAN, 1975-6, 87 ss.) (20).

En cuanto al segundo grupo, se presenta muy relacionado con el de las máscaras. Las figuras presentan forma acampanada y alas. Los rostros evocan las máscaras por las típicas manchas en las mejillas. Una de ellas lleva ramas en ambas manos, otra (fig. 7) presenta unos signos florales en el pecho, de clara relación con las figuras acampanadas de la Cueva de Es Cuieram de Ibiza, así como con la figura de la esfinge más arriba citada. Una más, sujeta con sus manos las riendas de dos caballos alados de los que se representan sólo los prótomos (fig. 8). En otro caso, aparecen dos de estas damas sosteniendo en sus manos unas aves, y en relación con ellas, un animal indeterminado y una serpiente.

Es evidente el carácter sagrado y mediterráneo de todas estas figuraciones: la presencia de las alas, las máscaras, la potnia hippon, la misma dendró-

(20) En la Península tenemos varios ejemplos de máscaras hathóricas en el ámbito tartésico, así la que aparece sobre un «braserillo» de la necrópolis de la Joya, en Huelva (MARÍN CEBALLOS, 1978, 26-27, pl. VII) o en algunas piezas del tesoro de la Aliseda (CARRIAZO, 1973, láms. 248, 256, 257; BLÁZQUEZ, 1975, lám. 49 a). 


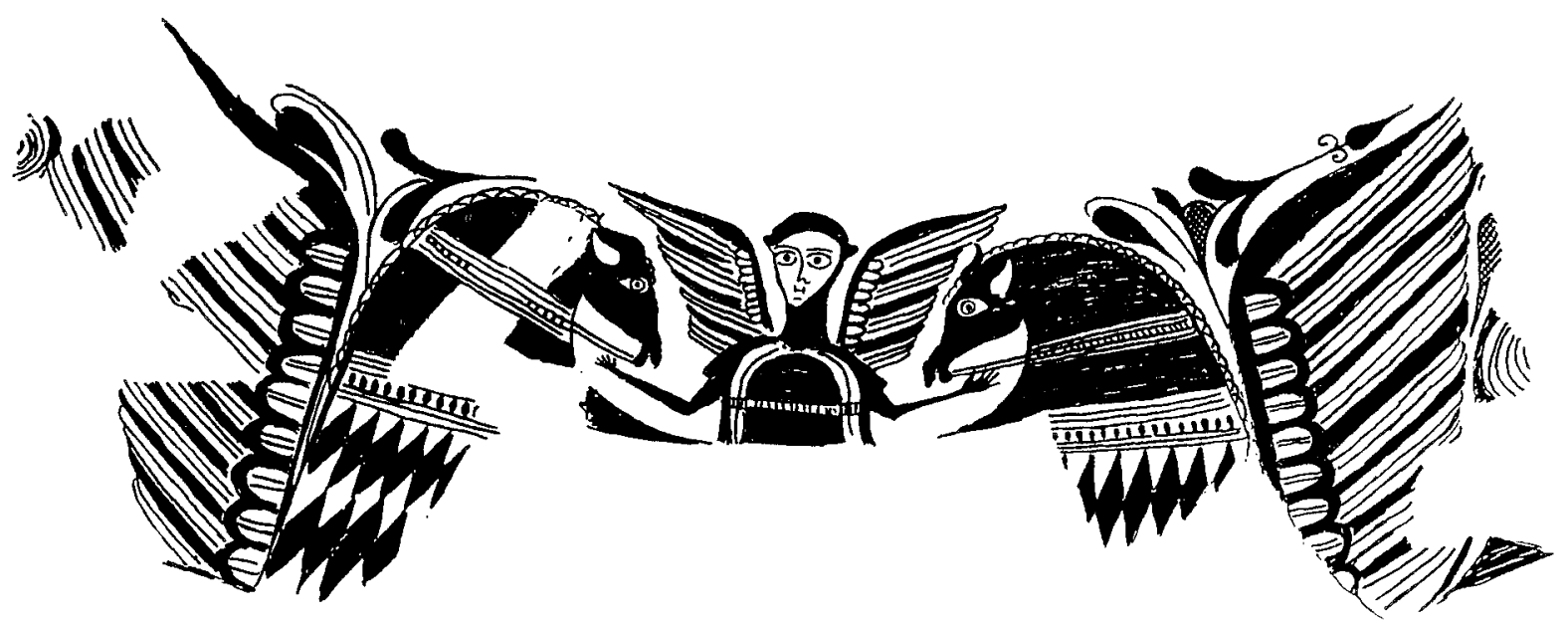

Fig. 8.—«Potnia hippon» de Elche, según S. Nordström.

fora. En unos casos parecen divinidades, en otros es posible que sacerdotisas, ataviadas como la diosa. ¿Se trata de una deidad local? La semejanza iconográfica con la representada en la esfinge del Parque Infantil de Elche, nos obliga a replantearnos el tema. No creemos pueda dudarse de la influencia de estas figuraciones aladas de Tanit, tan frecuentes en Ibiza (ASTRUC, 1962, 80). Se nos podrá objetar que la potnia hippon de Elche nada tiene que ver con Tanit (AUBET, 1976, 79, nota 38), pero todo parece indicar que estamos ante un culto muy sincrético, al menos en lo formal. En una navaja de afeitar ritual de Cartago, aparece una diosa con falda de alas flanqueada de dos patos o ánsares, en actitud típica de la potnia theron (PICARD, 1965-6, fig. 63, n. ${ }^{\circ} 34$, p. 70). Es muy posible que represente a Tanit (BLÁZQUEZ, 1983, 181-189).

De cualquier modo, nuestra idea es que la aquí representada es una deidad local, sincretizada o influida por divinidades extranjeras. Diosa de la fertilidad y la fecundidad de la vida natural y salvaje, es la misma divinidad de los caballos que tenemos bien documentada en lo ibérico y que tantos caracteres comunes tiene también con la Artemis griega (MARÍN CEBALLOS, 1983 b, 709-715, 1977) (21).

(21) No podemos dejar de mencionar aquí las estrechas afinidades que presentan las cabezas aladas de la cerámica ilicitana con las de la de Gnathia, según ha advertido acertadamente J. M. Luzón, a quien agradecemos la información (FORTI, 1965, lám. XIX O). En este sentido, es muy interesante la sugerencia de R. OLMOS (1987), que relaciona esta moda de las cabezas femeninas brotando del suelo, característica de la cerámica helenística, con el auge de los thymiateria estudiados páginas atrás.

\section{A MODO DE CONCLUSIÓN}

Para mejor valorar nuestra documentación, es preciso resumir lo que actualmente sabemos de la diosa Tanit, desde Fenicia a Cartago, pasando por los centros púnicos insulares de Sicilia, Cerdeña e Ibiza.

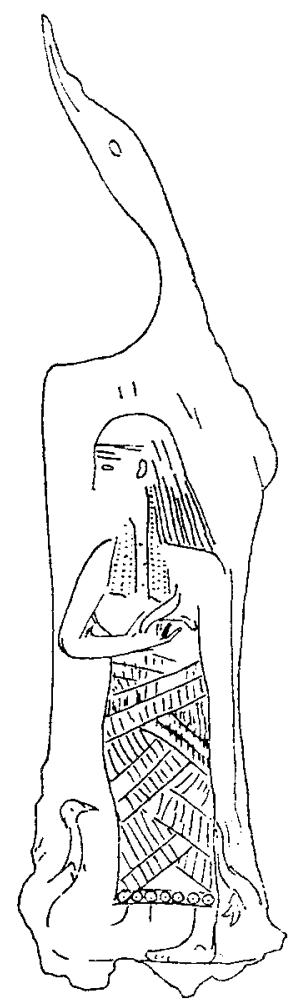

Fig. 9.-Figura grabada sobre la «navaja de afeitar» Ca 86 , de Cártago, según Acquaro. 


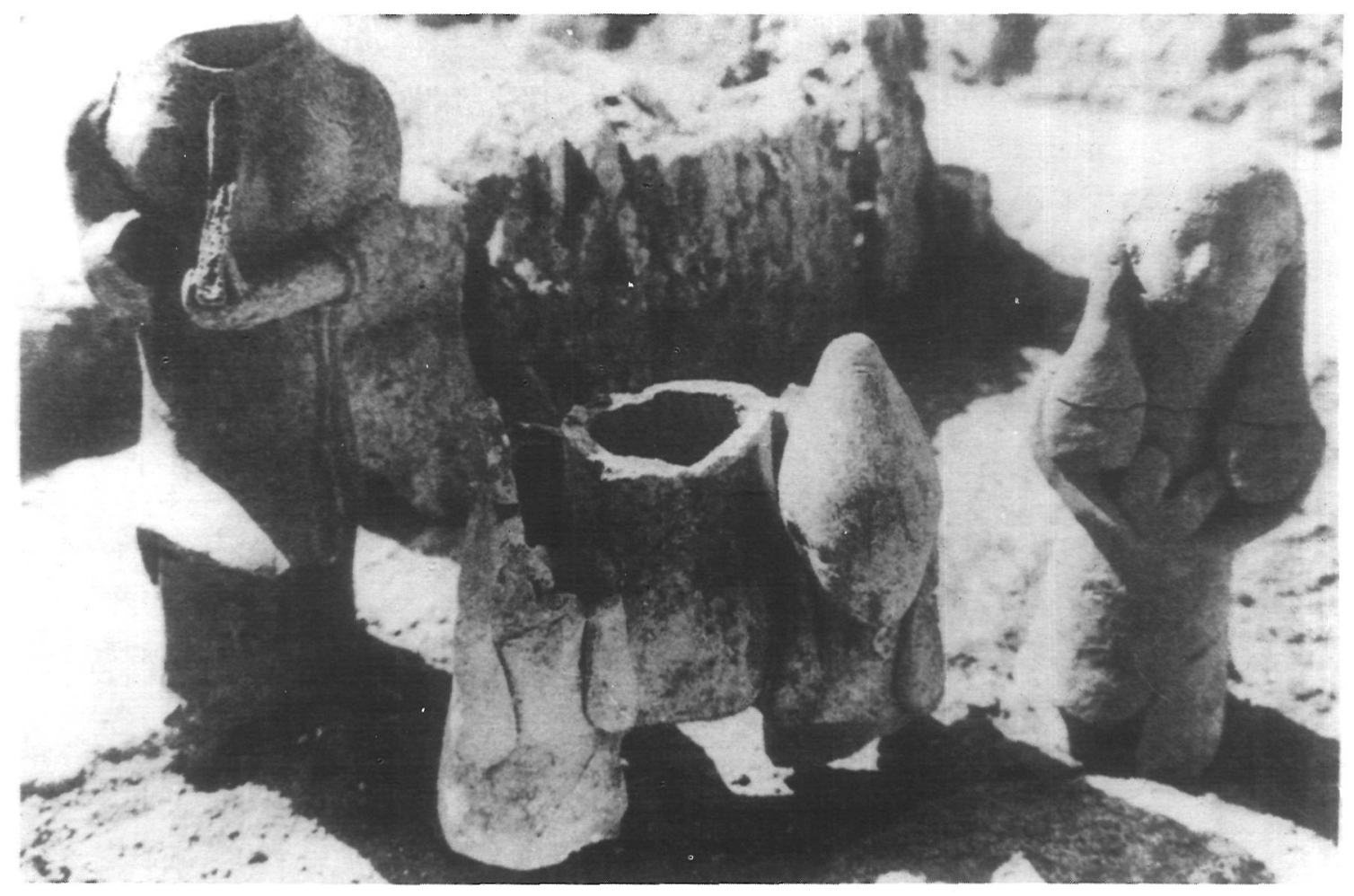

Lám. 19.-Terracotas figuradas del santuario de Tanit-Ashtart en Sarepta.

Los recientes hallazgos de Sarepta (PRITCHARD, 1978, passim) han permitido zanjar de una vez por todas la tan debatida cuestión del origen de la diosa. Pritchard ha encontrado allí una placa de marfil inscrita con el siguiente texto: «Estatua que Shillem, hijo de Mapa'al, hijo de Izai, hizo para Tanit Ashtart» (PRITCHARD, 1978, 104-107; MOSCATI, 1979, 143-4). La inscripción, fechada a fines del s. VII-comienzos del VI, apareció en un edificio, sin duda religioso, en las proximidades del puerto, que había conocido dos épocas, abarcando en total de los siglos VIII al IV (PRITCHARD, 1978, 11-148). Desgraciadamente, no se nos ha conservado la estatuilla, quizá de madera, objeto de tal dedicación, pero el material votivo aparecido en el templo puede ilustrarnos sobre los caracteres de la divinidad mencionada.

Junto a una abundante «pacotilla» egipcia (amuletos de Bes, Ptah, Bastet, Horus niño, oudjas, etc.), abundan las cuentas de collar, útiles de cosmética, y otros, aunque quizá lo más significativo sean las terracotas. Una de ellas representa a una figura de larga túnica, entronizada entre esfinges (lám. 19). Desgraciadamente no conserva su parte superior, lo que no nos permite asegurar si es un dios o una diosa, ya que en la larga tradición de reyes y dioses representados de esta forma en el mundo feniciopúnico (DE VAUX, 1967; UBERTI, 1975, 36 ss.), se dan las dos posibilidades. Otras terracotas representan a una mujer de pie con un ave en la mano o sentada tocando un tympanon (lám. 19). Del mayor interés es el tipo de la dama gestante entronizada, sin duda una diosa, bien conocida en el mundo fenicio, que estudiara Culican en un artículo con el expresivo título de Dea tyria gravida (22). Parece haber sido muy abundante en este santuario, con ejemplares que, según Culican, pueden datarse desde el siglo VII al IV, encontrándose representada en Fenicia, Palestina, Chipre y Cartago (PRITCHARD, 1978, 35-50 y figs.).

Concluye Pritchard, con respecto al templo de Sarepta, que debe tratarse de la sede de un culto

(22) CULICAN $(1969,35-50)$ apunta la posibilidad de que se trate de la diosa canaanita de la fertilidad, quizá la Koshart ugarítica, la Chusartis de Filon de Byblos (Eusebio, Praep. Eu. I, 10, 43), identificable a la diosa hipopótamo egipcia Thuro o Thoeris (43-44). Nuestra opinión es otra, como se verá más adelante. 


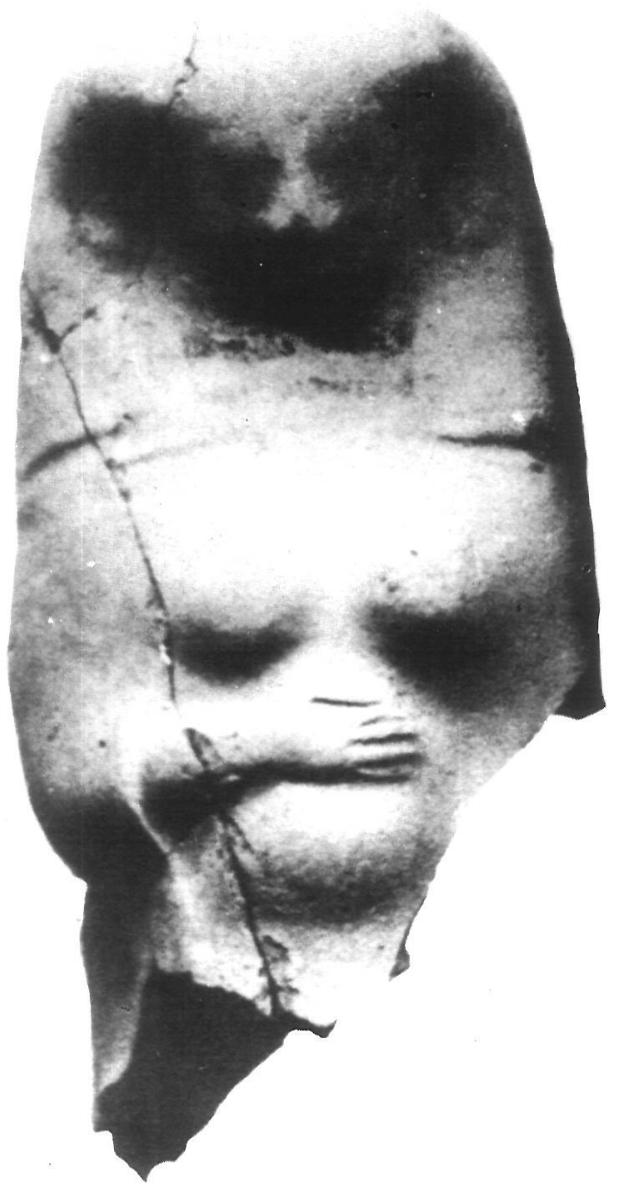

Lám. 20.-Figura del tipo «Dea Tyria graida» procedente de Sarepta.

practicado por mujeres y en honor de una diosa que protege sus intereses, en su opinión esa TanitAshtart de la dedicatoria. Otro problema sería ese doble nombre, que puede interpretarse de dos formas: o que en el siglo VII el culto a Tanit está unido al de Ashtart en un nombre doble como los de MlkStart, Reshef-Melqart, Sid-Melqart, etc., o que las dos diosas reciben culto juntas en este templo, y parece que se inclina más por esta segunda solución (ibídem, 107). En nuestra opinión, sin embargo, el hecho de que una sola estatua se dedique a las dos diosas podría ser significativo de que esa imagen las representa a las dos, en cuyo caso, obviamente, el doble nombre Tanit-Ashtart implicaría una fusión o identidad de ambas diosas, quizá Ashtart en su aspecto de Tanit.

Por otro lado, dado que una serie de exvotos del templo nos evocan más a una diosa maternal que a la Astarté erótica y guerrera, se nos ocurre que quizá habría que atribuir a Tanit ese carácter de madre fecunda y nutricia, lo que ciertamente viene avalado por la documentación fenicio-occidental sobre esta diosa (GARBINI, 1981, 131).

Tras el hallazgo de Sarepta, cobra nuevo valor la conocido inscripción de Cartago que hace referencia a «Tanit in Lbnn» (KAI 81), o la mención de una Abdtanit de Sidón en Atenas (KAI 53), así como el nombre de Gertanit sobre un ostrakon del siglo V del templo de Eshnmun en Sidón (DUNAND, 1967, 47-55, pl. I). Igualmente son sugerentes los topónimos modernos del Líbano, como Aitanit (BORDREUIL, 1965). También el llamado signo de Tanit está ampliamente documentado en Fenicia y concretamente en el templo de Sarepta (PRITCHARD, 1978, 107-8, DOTHAN, 1974, 4479; LINDER, 1973, 182-7).

Entre los más graves problemas que envuelven a la figura de Tanit está el de su aparición en Car- 
tago, y sobre todo el de su fulminante ascensión hasta encumbrarse en el panteón cartaginés, incluso por encima de su paredro Ba'al Hammon. Muchas explicaciones se han apuntado para este curioso fenómeno (23), aunque lo cierto es que hasta ahora ninguna suficientemente probada. Pero más que la cuestión de su origen, nos interesa aquí determinar los caracteres que, a través de la documentación, manifiesta la diosa en Cartago.

En primer lugar, Tanit es la diosa del tophet, junto con Ba'al Hammon. Es decir, ambas son las divinidades a quienes se consagran los sacrificios infantiles o de sustitución, que se relizan en el tophet. En efecto, si desde los orígenes de este rito, en Cartago y el resto del mundo púnico las dedicaciones se dirigen a $B a^{\prime}$ al Hammon, a partir del siglo $\mathrm{V}$ junto a aquél aparece Tanit, que gradualmente va sustituyendo a su paradero. No obstante, ya antes de que aparezcan tales dedicatorias a Tanit, encontramos imágenes femeninas en las estelas, que se interpretan como representaciones de la diosa (HVIDBERG-HANSEN, 1979, 38, 55). De las inscripciones sobre las estelas del tophet se desprenden además otros datos sobre Tanit. Hay dos procedentes de Cartago que la mencionan como «madre» (CIS I, 195, 1-2 y 380, 4-5) (ibidem, 18-19). Otra, de difícil interpretación (CIS I, 177) en que se muestra como «dea penetralis» o diosa protectora ( $i b i$ dem, 20-21).

La cuestión es la siguiente: ¿Qué relación tiene Tanit con el sacrificio infantil? La respuesta no es fácil. En primer lugar, Tanit parece ser, como paredra de Ba'al Hammon, la diosa tutelar de Cartago, al menos, con seguridad, desde el siglo V. Si los sacrificios tienen cierto carácter estatal, como apun-

(23) G. Garbini, por ej., piensa en la ascendencia de Sidón, en cuya región parece surgir el culto, sobre Tiro a partir del siglo VI, como consecuencia de la dominación persa. Se trataría de una reforma religiosa operada en la metrópolis africana que subordinaría al dios de Tiro, Baal Hammon, representación de la realeza sacra, a la diosa sidonia, lo que significa también una reafirmación de la oligarquía cartaginesa frente al régimen monárquico, y un medio de consolidar sus relaciones con Sidón. A la vez, así se adecuaba a otras ciudades importantes del momento como Atenas, cuya diosa Atenea se identificará con Tanit en su aspecto guerrero (GARBINI, 1980, 154 ss.). Otra explicación es la apuntada por GONZÁLEZ WAGNER (1983, 297 ss.) quien piensa que la expansión agrícola de Cartago en el Norte de África supuso un cambio en la superestructura ideológica de la sociedad cartaginesa, que conllevaría la adopción de una diosa de carácter agrícola y escatológico, así como la introducción de las diosas griegas Demeter y Kore, igualmente ligadas a la agricultura. tan algunos autores (24), es lógico que sean dedicados a la pareja que «reina» sobre la ciudad. Pero no nos parece suficiente explicación. La diosa se presenta además, desde Sarepta, con ese matiz de protección de los niños y la fecundidad (25), y ésta es quizá una razón de peso para tales dedicaciones.

Pero además, ella es muy probablemente también una diosa del «Más allá», que custodia a los muertos en su camino hacia esa vida ultraterrena, lo cual completaría su papel como diosa del tophet. Este carácter se resalta sobre todo en la presencia de figuraciones suyas en las tumbas; así, los pebeteros en forma de cabeza femenina, las estatuillas de diosa entronizada, las que la representan alada, etc... En este sentido, recordamos la idea de Culican (CULICAN, 1975-6, passim) de que las máscaras y prótomos femeninos que tan frecuentemente encontramos en las tumbas púnicas, costumbre que para él procede de la propia Fenicia, representan a la diosa de la muerte. Según este autor habría una diosa fenicia del Más Allá, quizá una de las hijas de $B a^{\prime} a l$ en los poemas ugaríticos: $A r s y$, que luego habría sido absorbida en Cartago por Tanit. En estas ideas se muestra muy próximo a Zuntz, para quien estas máscaras representan en el mundo siciliota a Perséfone (ZUNTZ, 1971, 142-157), que en este sentido se aproximaría una vez más a Tanit. Piensa Culican que ciertos rostros esculpidos, así como cipos antropomorfos, cumplían probablemente la misma función que las máscaras; recuerda, por ejemplo, las del recinto de la Malophoros en Selinute (26). Otro aspecto de inteŕes es la aparición frecuente de pebeteros, en fauissae o templos, en la proximidad de necrópolis.

En las estelas aparecen diversas figuraciones femeninas que se han interpretado como representación de Tanit: así la diosa entronizada (fig. 10).

(24) Asi ACQUARO Y BONDI piensan que tal sacrificio, aún realizándose en el ámbito privado de la familia, era regulado y controlado por el Estado. Se trataba de una manifestación del culto oficial de la ciudad (GARBINI, 1981, 128-9).

(25) Es hecho admitido por la mayoría de los autores que uno de los objetivos principales del sacrificio era obtener la fecundidad (GARBINI, 1981, 130).

(26) Recordamos a propósito un curioso cipo de Villaricos que A. M. BISI cree a fines deI s. VI $(1965$ c, 43-45, fig. 1, e). Tiene forma de prisma, con remate piramidal. Por uno de los lados la base tiene esculpido en relieve un capitel eólico, y por el otro, una cabeza que Bisi paraleliza, por el estilo y la forma de ir adosada a una pilastra, con otros de estilo egipcio-chipriota, procedentes de Chipre. Dicha autora cree que se trata de una cabeza masculina tocada con klaft. (ASTRUC 1951, 175, 158, 164, 156, lám. L, 3, 6). 
(PICARD, 1957, I, lám. XXVI, CB 1076 y 1077, II, 299; BISI, 1965, 128-9), o la que, desnuda o no, se presiona los senos (27), o la dama con el disco o tympanon (28), la flor, o el signo ankh (MOSCATI, 1981, 189-191; BISI, 1967, 176, tav. LIX, $2 ; 1965,145)$, o la que se muestra con un niño pequeño (29). Igualmente, aquéllas en que la diosa se muestra alada y en relación con el creciente y la paloma (fig. 11) (30). Además, algunos de los símbolos frecuentes en las estelas se relacionan también con la diosa: en primer lugar el llamado «signo de Tanit» (MOSCATI, 1981 b, 113-116; HVIDBERGHANSEN, I, 41; BISI, 1980, b, 211-229; GARBINI, 1980 b, 177-179; HUSS, 1985, 536-7), el signo de la botella (HUSS, 1985, 536-7), la losange (ibidem; CECCHINI, 1970, 245-7).

Resumiendo pues: de la documentación del tophet se desprende la relación de Tanit con el sacrificio infantil, que deriva quizá de su carácter de diosa tutelar de Cartago, junto con $B a^{\prime}$ al Hammon, su paredro; pero al mismo tiempo puede derivar de su carácter de diosa de la fecundidad, concretado en su aspecto maternal y nutricio, de protección a los niños, así como de su matiz de deidad psicopompa y guardiana de la muerte. Por otra parte, y en cuanto a la forma, se resalta que es una diosa alada, lo que supone, de un lado, un matiz de protección, y de otro ese mismo carácter celeste de la diosa que se evidencia en su relación con los astros y en especial con el creciente.

(27) Especiaimente en Nora, Sulcis y Monte Sirai. Sólo una vez en Cartago. Parece que se trata de una influencia directa de Fenicia sobre Cerdeña (BISI, 1967, 224-225).

(28) Tal figuración, característica de las estelas de Sulcis, aunque se da también en otros lugares, se ha venido interpretando como típica de Astarté y quizá Tanit (FERRON, 1969, 1133; BISI, 1980, 57-76). No obstante, recientemente S. MOSCATI cree que se trata de una sacerdotisa tocando el pandero, ceremonia que debió ser importante en el rito del tophet, así como en el funerario (1986, 62 ss.).

(29) Estela de Monte Sirai. GARBINI (1964, n. ${ }^{\circ} 48,90-92$, lám. XXXVI, XLVI) la interpreta como Tanit llevando en sus brazos a la víctima del sacrificio. Igualmente BISI $(1965,148)$. C. PICARD en cambio $(1969,479)$ piensa en Tanit curótrofa.

(30) En una estela de Cartago la figura alada se sitúa bajo un gran creciente, sosteniendo bajo el pecho una especie de cuenco cargado de frutos, que también tiene forma de media luna (BISI, 1967 , fig. $47 ; 1965,118$ ). Dicha estela puede relacionarse con otra procedente de Bulla Regia, fechada en el cambio de era, en que un busto femenino desnudo, de grandes pechos, surge de un gran creciente con las puntas hacia arriba (PICARD, 1957, CB 95, t. I, 257: BISI, 1965, 137-8), y otra de Siagu, en que el busto femenino se muestra con cabeza coronada por el creciente, y una paloma entre los brazos.

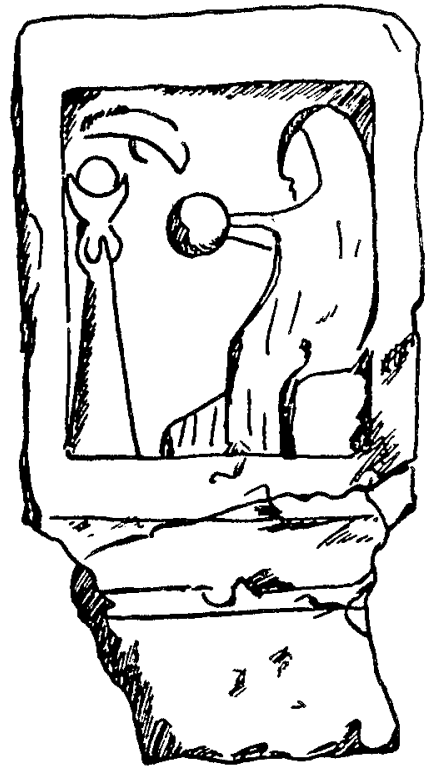

Fig. 10.-Estela del tophet de Susa, apud A. M. ${ }^{a}$ Bisi.

El resto de la documentación no hace más que confirmar o reforzar los caracteres mencionados:

Como diosa tutelar de Cartago, paredra de $B a^{\prime} a l$ Hammon, se nos muestra en los santuarios, principalmente en el descubierto por Carton junto a la estación de Salammbó, en Cartago (CARTON, 1949, passim), donde se hallaron dos fragmentos de estatuas entronizadas que quizá sean representacio-

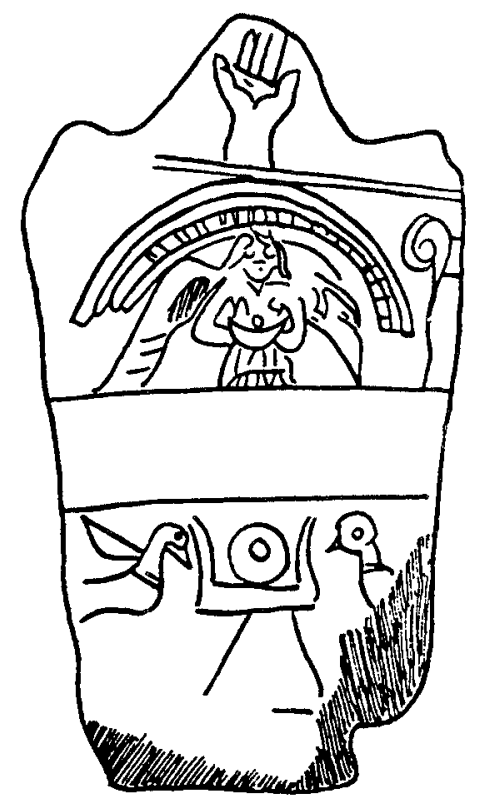

Fig. 11.-Estelas del tophet de Cartago, apud A. M. Bisi. 
nes de Ba'al Hammon y Tanit (ibidem, pl. I, 2. PICARD, 1970, 55 ss.), junto con pebeteros en forma de cabeza femenina, figuras de la diosa alada, etc. (véase supra). También en el santuario de Bir Bou Rekba (Thinissut), de comienzos de la era, consagrado, según la inscripción a Ba'al HammonSaturno y Tanit-Caelestis (MERLIN, 1910, passim). Allí la diosa aparece relacionada con el león, como lo estuviera la Atargatis siria, y antes que ellas $A s h$ tart (HVIDBERG-HANSEN, 1979, 23 ss.). Se le representa de pie sobre el animal, o como figura alada leontocéfala, que deriva a su vez de la egipcia Sekhmet. Entronizada entre leones aparece también la diosa en una estatua de Motya (UBERTI, 1975 b, 33-39, tav. II-III). Es común opinión que la relación con el león indica el aspecto guerrero de Tanit, como de sus antecesores (PICARD, 1954, 71; HVIDBERG-HANSEN, 1979, 23 ss.), así como que la diosa leontocéfala que aparece en las monedas romanas de África del Norte con la inscripción G.T.A. (Genius Terrae Africae) es la misma Tanit representada como Dea Africa (PICARD, 1954, 7071; GSELL, 1924, 273-275).

Su carácter de diosa madre y nutricia se confirma igualmente por otras representaciones de mujer con niño en los brazos (PICARD, 1969), aspecto éste que le aproxima sobre todo a la egipcia Isis, y en cierto modo a la griega Demeter, y que en época romana pervivirá en la afro-latina Nutrix.

Muy documentada está igualmente la iconografía alada de la diosa en santuarios y tumbas. Recuérdese, sin ir más lejos, el sarcófago de Santa Mónica (véase supra). Este carácter la relaciona con la egipcia Isis y con la griega Artemis, con quien parece identificarse profundamente (HVIDBERGHANSEN, 1979, 19-20). Esta figura alada, sobre todo cuando la encontramos en las tumbas, nos hace pensar en Isis y su función de protectora del muerto, y al mismo tiempo sugiere un matiz de diosa psicopompa que encontramos confirmado en la relación con Hermes y el caduceo (31). Pero también las alas le caracterizan como diosa celeste, junto con otros elementos estelares con que la vemos, por ejemplo, en las navajas rituales (PICARD, 1965-6, fig. 58, lám. XXIII, n. $\left.{ }^{\circ} 25\right)$, y sobre todo se confirma en la aparición de la Dea Caelestis de época romana

(31) Así en el «rasoir» n. ${ }^{\circ} 13$ del catálogo de C. PICARD (1965-6, pl. XVIII, fig. 53, pp. 62-63), de fines del siglo IV, en que por un lado aparece una Isis-¿Tanit?, protegiendo al niño Horus con sus alas y, por el reverso, Hermes con el caduceo.
(HVIDBERG-HANSEN, 1969, 24-25). En este sentido se remarca sobre todo su carácter lunar (GSELL, 1924, 247 ss.).

Intentaremos ahora insertar la documentación hispana en este ambiente, tratando de situarla también en el contexto de la cultura ibérica. Veamos en primer lugar los pebeteros en forma de cabeza femenina. ¿Qué significa su presencia en la Península? De los datos anteriormente expuestos, deducimos la conexión originaria con el hecho de quemar perfumes, aunque no de forma exclusiva, ya que los encontramos igualmente sin las tapas superior e inferior, que posibilitan dicha función. Tampoco parece exclusiva su relación con el más allá, pues los hay también en templos y fauissae. Su presencia en silos parece exclusiva del área noreste peninsular. Nos preguntamos si estos silos no habrían desempeñado el papel de meras fauissae, pues en ellos aparecen también otras terracotas votivas, junto con cerámica, etc. O quizá haya que atribuirle un sentido concreto a su aparición en ellos, quedando entonces destacado un especial matiz de diosa protectora de la agricultura.

En cuanto a esos «santuarios» al aire libre, en pequeñas alturas, junto con la proliferación de imitaciones locales, algunas de ellas ya tan «desfiguradas» con respecto a los modelos, en definitiva ese éxito manifiesto de los pebeteros en el ámbito ibérico, nos obligan a pensar que el culto ha calado de un modo especial entre los iberos. Quizá por identificarse con una divinidad local de la muerte y la fecundidad, deidad que es probablemente la misma representada en las estatuas de dama entronizada en ambientes funerarios, cuyo prototipo, al ser mejor conocido su contexto, es la Dama de Baza (PRESEDO, 1973).

Ese mismo carácter de diosa que protege en el trance de la muerte cabe deducirlo de las figuritas de diosa nutricia halladas en necrópolis de influencia púnica: Albufereta, Verdolay. Nos llama la atención, no obstante, la preferencia local por el aspecto nutricio de la diosa, y en este sentido recordamos la estatua de alabastro conocida como «Astarté» de Galera (Granada) (RIIS, 1950, 113 ss; MARÍN CEBALLOS, 1978, 28-30), en que la diosa se representa entre esfinges, y cuyo rasgo más destacado es el hecho de ser en realidad un vaso de libaciones, vertiéndose el líquido, probablemente leche, por el orificio de la parte superior de la cabeza, yendo luego a salir por los perforados pechos de la diosa. Esa imagen femenina con un gran cuenco bajo el 
busto, nos evoca a la que se muestra sobre una estela de Cartago, en que el cuenco se sustituye por un gran creciente lleno de frutos (fig. 11), y otra de Bulla Regia, con grandes pechos desnudos que se sitúan igualmente sobre un creciente (BISI, 1967, fig. 44; PICARD, c. 1957, lám. C, CB-950) (fig. 12).

Pero además Tanit es en Elche, a nuestro entender de forma evidente, una diosa psicopompa, que conduce y guía al muerto, como criatura desvalida, en su camino hacia el Más Allá. Y, una vez más, se nos muestra relacionada con la esfinge, convertida aquí en su auxiliar y acólito. Quizá nunca la diosa se había mostrado de forma tan clara con este carácter, que ahora nos ayuda a entender su relación con Hermes y con el caduceo, del que A. M. Bisi ha demostrado el origen griego (BISI, $1965 \mathrm{~b}$, 1-6). La estatua de Elche posiblemente decorara la tumba de un ibero que, habiendo asimilado la ideología funeraria implícita en su culto, ha querido expresarla con su lenguaje propio: la escultura de esfinge, tan usual en el Levante ibérico a manera de estela o formando parte de la decoración escultórica de la tumba (CHAPA, 1980 b; ALMAGRO GORBEA, 1983). Esta Tanit psicopompa es probablemente la misma que se evoca en el anillo procedente de Montemolín (Marchena, Sevilla), que hemos estudiado recientemente (BANDERA y MARÍN CEBALLOS, 1985, 227-231). Fechado en el siglo III a. de C., en su chatón se ha grabado una figura femenina tocada con una degeneración de la doble corona egipcia o pschent, que lleva en su mano derecha un caduceo.

Como apuntábamos más arriba, Elche aparece como uno de los enclaves ibéricos más claramente influidos por Cartago, y de forma especial se nos muestra esto en la cerámica pintada. Nuestra idea es que realmente esa figura de forma acampanada con alas recuerda representaciones de Tanit, pero una Tanit que, ya en esa época, se halla plenamente sincretizada en Levante con una deidad indígena relacionada con los caballos, y quizá con esa Artemis Efesia difundida por los focenses en las ciudades portuarias de nuestra costa oriental (PENA, 1973, 121 ss. y notas). Elche se muestra, pues, como un nudo crucial de influencias greco-púnicas.

Es importante mencionar aquí igualmente la existencia del importante cipo-estela del Museo gaditano, rescatado recientemente de entre los muros de la casa de Pelayo Quintero, y que ya había sido dado a conocer por el mismo (PELAYO, 1931, 7-8). Procedente del área de la necrópolis de Cádiz, lo que más resalta en él es la figuración que aparece en relieve en su cara anterior, y que muy probablemente representa un signo de Tanit, un tanto degenerado, con un mayor desarrollo del que corresponde a la cabeza, que generalmente es un círculo perfecto y aquí se ha alargado, uniéndose al triángulo inferior con un muy tenue trazo horizontal. Sin pretender entrar aquí en la importante problemática que plantea (32), nos interesa resaltar la presencia de ese símbolo (33), y su posible relación con un tophet, lo que vendría a confirmar la fuerte influencia cartaginesa sobre Cádiz a partir del siglo V (AUBET, 1986, 615-16), y por supuesto, el culto que la ciudad debió dar a la diosa Tanit. Precisamente, el primitivo enclave de la ciudad gaditana: la Erytheia de las fuentes, se conocía por los autores latinos como isla de Iuno, nombre que probablemente transcribe el de la diosa púnica (PLINIO, N.H IV, 120). Hay otros enclaves destacados de la costa Sur de la Península que recibían apelativos igualmente relacionados con Hera o Iuno, seguramente por parte de navegante púnicos (34). Abundando en ello, resulta de interés la sugerencia reciente de María E. Aubet, de que la llamada Cueva de Gorham, en Gibraltar, le hubiera estado igualmente consagrada (AUBET, 1986,616 y 622-23).

Es manifiesto que nuestra intención en este trabajo ha sido valorar, desde el punto de vista del conocimiento actual del culto a Tanit, una documentación en gran parte ya conocida. Tales testimonios, lógicamente, han de insertarse en el acerbo docu-

(32) Está por un lado el problema de su datación, pero sobre todo el de la posible existencia de un tophet en el área de la necrópolis gaditana. Eś interesante a este propósito recordar el reciente hallazgo de un conjunto de enterramientos de niños de edades comprendidas entre seis meses y diez años, cuyos cráneos aparecen fracturados a propio intento, fechable en el siglo I a. de C., que muy probablemente signifique la pervivencia del rito del sacrificio infantil en época romana (CORZO, 1983, 20-22; CORZO Y FERREIRO, 1983; MARÍN CEBALLOS, 1983, 35-37).

(33) Sobre el signo de Tanit y su significado véase $p$ Recientemente M. J. FUENTES $(1983,282)$ ha dado a conocer una nueva representación del mismo, estampillada sobre un asa de ánfora y acompañada de un caduceo. Es interesante mencionar aquí el motivo figurativo repetido en torno a un vaso del santuario ibérico de La Serreta, que podría evocar, de un modo lejano, el citado símbolo (VISEDO, 1923, n. ${ }^{\circ} 56,5$, lám. Il A).

(34) Una isla de Fiera, de la que se dice que contenía un santuario de la diosa, es citada por Estrabón IIl, 5, 3-5, quien cita como fuente a Artemidoro (s. IV a. de C.) Un cabo de Iuno (Iunonis Promunturium) es mencionado por Mela (II, 96) y Plinio (III, 7) entre Gades y Baesippo. Mela (IIl, 4) menciona también el altar y templo de Iuno (Iunonis ara templumque) entre el Castellum Ebora y el Monumentum Caepionis. 


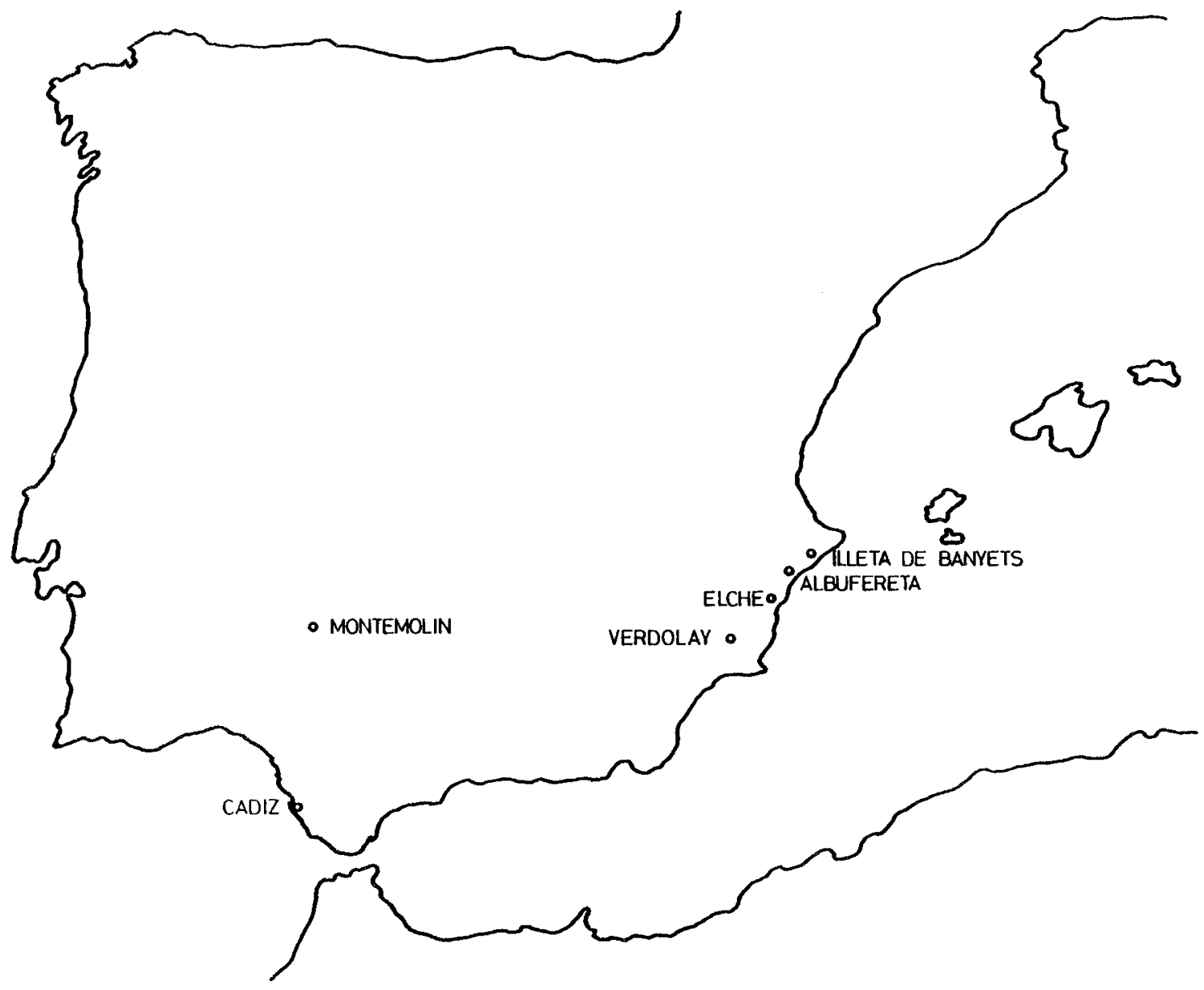

Mapa n. ${ }^{\circ}$ 3: Otros testimonios estudiados.

mental de carácter histórico-arqueológico sobre la presencia de Cartago en la Península.

Distamos mucho, aún hoy, de ver esta presencia con claridad. No obstante, y aunque muy lentamente, se va desbrozando el camino para entender esas vagas pero evidentes alusiones de las fuentes clásicas (35). Hoy es patente la acción de Cartago en las viejas - y en algunos casos nuevas - colonias del Sur y Sudeste (36), desde donde continúa, y pro-

(35) Asi, el segundo tratado del 348 entre Roma y Cartago; las abundantes noticias sobre la utilización de mercenarios ibéricos, en las guerras emprendidas por Cartago en el Mediterráneo desde fines del siglo VI; las frecuentes alusiones a gente de raza púnica o mezclada con población indígena, en el Sur peninsular; las que hacen referencia al cierre del Estrecho por parte de los cartagineses (recogidas por BLÁZQUEZ, 1983, 178, s.)

(36) Fundamentalmente en Gadir, Guadalhorce, Jardín, Malaka, Almuñécar y Villaricos (AUBET, 1986, 612-623). bablemente potencia, la actividad comercial con el resto de la Península (37). Para entendr este fenómeno han sido de gran utilidad las ideas de la escuela de Polanyi acerca de lo que ellos llaman «comercio administrativo», basado en las relaciones estableci-

(37) Con respecto a Levante, es obvio que una corriente comercial que pudiéramos denominar «cartaginesa» sucede, tras un breve eclipse hacia mediados del siglo VI, a los viejos contactos establecidos desde las colonias del Sur, ya desde el siglo VIII (ARTEAGA, PADRÓ Y SANMARTÍ, 1986, 303 ss.; GONZÁLEZ PRATS, 1986, 279 ss.). En lo que se refiere a Ampurias, recientemente A. PUJOL (1984-5, 27-28), opina que quizá la ciudad pudo actuar como centro distribuidor de productos cartagineses, lo que explicaría el auge emporitano durante el siglo $\mathrm{V}$. Peor conocida, aunque indudablemente existe, es la penetración comercial cartaginesa a lo largo del Valle del Guadalquivir. En todo caso, parece que los contactos establecidos con el área Sur peninsular son de carácter diferente, y por tanto dejan huellas también muy distintas. 


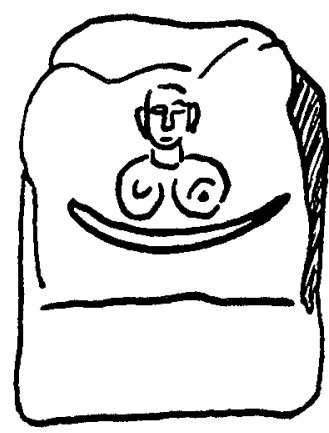

Fig. 12.-Estelas del tophet de Cártago, apud A. M. Bisi.

das en los «puertos de comercio», entre intereses económicos varios, en razón a un equilibrio que asegure y garantice el libre comercio en los mismos (REVERE, 1976, 87-108).

Pensamos, no obstante, que esta actividad comercial, con ser muy importante, no es suficiente para entender la actuación cartaginesa en la Península (38). Es mucho lo que desconocemos sobre el tema, pero todo parece indicar que existen pequeñas «colonias» o grupos más o menos numerosos de gentes de procedencia cartaginesa establecidos no sólo en las viejas fundaciones fenicias, sino en ciudades ibéricas de especial significación, económica, ya puertos comerciales como Elche, enclaves agrículas como Carmona y otros puntos del valle del Guadalquivir (GONZÁLEZ, 1973, 457-8; BENDALA, 1986; JIMÉNEZ, 1977, 233 ss.; BELÉN et alii, 1986, 59-60) (39), o lugares clave para la obtención y el transporte del metal (40). Sobre esta infraestructura, pensamos, actuó la dominación

(38) Por el contrario, GONZÁLEZ WAGNER (1983, passim) cree que la actuación cartaginesa anterior a los Barca en la Península se limitó a un «imperialismo indirecto», de tipo comercial, basado en el control de los «puertos de comercio». Según esto, la nota distintiva de la dominación Bárcida consistiría precisamente en sustituir ese imperialismo indirecto por un control territorial directo.

(39) En el rastreo de las huellas dejadas por Cartago, nos parecen de gran utilidad las fuentes numismáticas (CHAVES Y MARÍN CEBALLOS, 1987)

(40) Hay ciudades como Olont o Ituci (Tejada la Vieja, Escacena, Huelva) que en los inicios de la dominación romana acuñan moneda con letreros en alfabeto púnico. En relación con el control de las rutas del metal, está aún por definir en sus justos términos cuál haya sido el papel de Cártago en la construcción de los recintos fortificados y atalayas que estudiaran FORTEA Y BERNIER (1970), fechables desde el siglo V en adelante, cuya técnica constructiva presenta estrechos paralelos con estructuras semejantes utilizadas por los cartagineses en Cerdeña y N. de África (BARTOLINI, 1973, 109; GONZÁLEZ WAGNER, 1983, 245-6 y notas).
Bárcida, potenciando, durante un brevísimo espacio de tiempo, actividades que sin duda venían realizándose desde mucho antes por gentes de su raza, en muchos casos ya mezclada con población hispana, lo que explicaría términos como bastulofenices o blastofenices (APIANO, Iber., 56), que aparecen en las fuentes clásicas.

\section{BIBLIOGRAFÍA}

ABAD CASAL, L. 1985: «El yacimiento ibérico del Castillo de Guardamar». Festes de Guardamar

- 1986: «Castillo de Guardamar», Arqueología en Alicante 1976-86. Alicante

ACQUARO, E. 1978: «Tharros à la lumière des nouvelles recherches», II Congrès International d'Étude des Cultures de la Méditérranée Occidentale. Alger

ALMAGRO BASCH, M. 1953: La necrópolis de Ampurias vol. I, Barcelona

ALMAGRO GORBEA, M. J. 1967: Excavaciones arqueológicas en Ibiza. Madrid

- 1980: Corpus de las terracottas de Ibiza. Bibliotheca Praehistorica Hispana XVIII, Madrid

- 1980 b: Catálogo de las terracottas de Ibiza del Museo Arqueológico Nacional

- 1983: «Un depósito votivo de terracotas de Villaricos», Homenaje a $M$. Almagro $I I$.

ALMAGRO GORBEA, M. 1983: «Pilares-estela ibéricos». Homenaje a $M$. Almagro $I I$.

ARTEAGA, O., PADRÓ, J., SANMARTÍ, E. 1986: «La expansión fenicia por las costas de Cataluña y el Languedoc», Los Fenicios en la Península Ibérica

ASTRUC, M. 1951: La necrópolis de Villaricos, Informes y Memorias n. 25 Madrid

- 1956: «Traditions funéraires de Carthage», Cahiers de Byrsa VI.

- 1962: «Échanges entre Carthage et l'Espagne d'après le témoignage de documents céramiques provenant d'anciennes fouilles», Revue des Études Anciennes 64, 1-2

AUBET, M. E. 1976: «Algunos aspectos sobre iconografía púnica: las representaciones aladas de Tanit». Homenaje a A. García y Bellido I, Revista de la Universidad Complutense $X X V, 101$

- 1982: El santuario de Es Cuieram, Ibiza. Ibiza

- 1986: «La necrópolis de Villaricos en el ámbito del mundo púnico peninsular», Homenaje a L. Siret.

BAENA DE ALCÁZAR, L. 1977: «Dos nuevos pebeteros con cabeza femenina aparecidos en Málaga», $X V C A N$

- 1977 b: «Pebeteros púnicos de arte helénico hallados en Málaga», Jábega $X X$

BALIL, A. 1952: «El poblado layetano del Turó de Can Oliver en Sardañola (Barcelona), AEArq.

BANDERA, M. L. y MARÍN CEBALLOS, M. C. 1985: «Sortijas ibéricas de imitación fenicio-púnica», $R S F X I I I, 2$

BARNETT, R. D. 1960: "Some Contacts between greek and oriental Religions» Elements Orientaux dans la religión Grècque Ancienne, París

BARRECA, F. 1965: Monte Sirai II. Roma

BARTOLINI, P. 1973: RSF $I, 1$

BELDA, J. 1946: «Algunos restos del antiguo culto a la diosa religioso-funeraria», CASE II

- 1950-1: «Museo Arqueológico provincial de Alicante», Memorias de los Museos Arqueológicos Provinciales $X I-X I I$ 
BELÉN M. ET ALII, 1986: «Rituais funeraris a la necropolis romana de Carmona (Sevilla)», Cota Zero 2

BELTRÁN, A. 1953: «Los monumentos en las monedas hispanorromanas», AEArq. 26

BELL, M. 1972: «Two terracotta bust from the Iudica Collection», Archeologia classica $X X I V, 1$

BENDALA, M. 1986: «Die orientalischen Religionen in vorrömischer und römischer Zeit» $A N R W I I$ : Principat, vol. XVIII, 1 .

- 1986 b.; «Aproximación al urbanismo prerromano y a los fenómenos de transición y de potenciación tras la conquista", Los asentamientos ibéricos ante la romanización. Madrid (en prensa)

BISI, A. M. 1965: «La religione punica nelle rappresentazioni figurate delle stele votive», Studi e Materiali di Storia delle Religioni $X X X V I, 1$

- 1965 b: «Il caduceo nel mondo punico», Byblos Press VI, 1

- 1965 c: Kypriaka. Contributi allo studio della componente cipriota della civilità punica, Palermo.

- 1966: "Motivi sicelioti nell'arte punica di età ellenistica», Arch. Class, XVIII, 1

- 1967: Le stele puniche, Studi Semitici 27, Roma

- 1968: «La religione punica in Sicilia alla luce delle nuove scoperte archeologiche», Studi e Materiali di Storia delle Religioni, $X X X I X, 1$

- 1975: «Sull'iconografia di due terrecotte puniche de Ibiza», Studi Magrebini VII

- 1978: "Le terrecotte figurate di tipo grecopunico di Ibiza 11I: Museo de Ibiza», Rivista di Studi Fenici VI, 2

- 1980: «Les déesses au tympanon de la Mésopotamie à Carthage», Assyriological Miscellanies I, Copenhagen

- 1980 b: «Ancora sull'origine del seno di Tanit», Miscellanea di Studi Classici in onore di E. Manni I. Roma

- 1983: «L'expansione fenicia in Spagna», Fenici e Arabi nel Mediterraneo. Roma

- 1986: «La coroplastia fenicia d'Occidente (con particolare riguardo a quella ibicenca)», Los Fenicios en la Península Ibérica, I, Sabadel

BLANCO, A. 1960: «Die klassischen Wurzeln der iberischen Kunst», Madrider Mitteilugen I

BLANCO A. Y CORZO, R. 1983: «Monte Algaida. Un santuario púnico en la desembocadura del Guadalquivir», Historia 16,87

BLANCO C. 1970: «Nuevas piezas fenicias del Museo Arqueológico de Cádiz», AEArq, 43

BLÁZQUEZ, J. M. 1975: Diccionario de las religiones prerromanas de Hispania. Madrid

- 1975 b: Tartessos y los orígenes de la colonización fenicia en Occidente. Salamanca $\left(2 .^{2}\right.$ ed.)

- 1983: Religiones Prerromanas. Madrid

- 1983 b: «La expansión cartaginesa», Historia de España Antigua 1: Protohistoria. Madrid (2. ${ }^{\mathrm{a}}$ ed.)

BLECH, M. 1981: «Esculturas de Tajo Montero (Estepa): una interpretación iconográfica», La Religión Romana en Hispania. Madrid

BONET, H. 1978: «Fragmento de rostro de terracota, procedente del poblado ibérico del Castellet de Bernabé (Liria)», Archivo de Prehistoria Levantina $X V$

BONET, H. Y MATA, C. 1981: El poblado ibérico del Puntal dels Llops [El Colmenar (Olocau)], Valencia.

BORDREUIL, P. 1985: «Tanit du Liban», Phoenician and the East Mediterranean in the first millenium $B$. C. (en prensa)

BOSCH P. 1920: AIEC VI

- 1937: L'art grec a Catalunya, Barcelona

BRONCANO, S. Y BLÁNQUEZ, J. 1985: El Amarejo (Bonete, Albacete), Madrid
CARRIAZO, J. 1973: Tartessos y el Carambolo, Madrid

CARTON, L. 1929: Sanctuaire punique découvert à Carthage, Paris

CECCHINI, S. M. 1969: I ritrovamenti fenici e punici in Sardegna, Roma;

- 1970: Oriens Antiquus IX

CINTAS, P. 1949: «La kernophoria à Carthage», $C R A I$

- 1950: Céramique Punique, Túnez

- 1952: «La Gran Dame de Carthage», CRAI

- 1954: Contribution à l'étude de l'expansion carthaginoise en Maroc. París

CLERMONT-GANNEAU, M. 1904: CRAI

COLOMINAS, J. 1915-20: «Necrópolis de Can Fatjó, Rubí», $A I E C$ VI

CORZO, R. 1983: «Cádiz y la arqueología fenicia», Anales de la Real Academia Provincial de Bellas Artes de Cádiz, 1

CORZO, R. Y FERREIRO, M. 1983: «Sacrificios humanos en el Cádiz antiguo», II Congreso Andaluz de Estudios Clásicos, Málaga-Antequera, en prensa

CULICAN, W. 1968: "The Iconography of some phoenician Seals and Seal Impressions», Australian Journal of Byblical Archaeology I

- 1969: «Dea tyria gravida», AJBA I, 2

- 1975-6: «Some phoenician Mask and other Terracottas», Berytus 24

CHAPA, T. 1980: «Las esfinges en la plástica ibérica», Trab. de Preh. 37

- 1980 b: La escultura zoomorfa ibérica en piedra. Tesis doctoral reprografiada. Madrid

CHAVES, F. Y MARÍN CEBALLOS, M. C. 1987: «L'influence phénico-punique sur l'iconographie des frappes locales de la Péninsule Ibérique», Numismatique et Histoire Économique dans le Monde Phénicopunique, Louvain-la-Neuve, en prensa

DELATTRE, A. L. 1901: Carthage: nécropole punique voisine de Sainte-Monique. Second mois des fouilles (février 1898) Paris

- 1906: La nécropole des Rabs, prêtres et prêtresses de Carthage. Troisième année des fouilles. Paris

- 1924: Une favissa à Carthage. Figurines de Démeter et brûleparfums votifs. Tunez

DOTHAN, M. 1974: «A Sign de Tanit from Tell'Akko». IEJ 24

DUNAND, M. 1967: $B M B, 20$

FAEDO, L. 1970: «Contributo allo studio della coroplastica selinuntina", Arch. Class. XXI, 1-2

FERNÁNDEZ, J. H. 1980: El hipogeo de Can Pere Catalá des Port (Sant Vicent de Sa Cala, Trab. del M. A. de Ibiza 4

FERNÁNDEZ, J. H. Y PADRÓ, J. 1982: Escarabeos del Museo Arqueológico de Ibiza, Trabajos del M. A. de Ibiza

FERNÁNDEZ AVILÉS, A. 1944: «Rostros humanos de frente en la cerámica ibérica», Ampurias VI

FERNÁNDEZ FUSTER, L. 1947: AEArq. XX

FERRON, J. 1969: «Les statuettes au tympanon des hypogées puniques», Antiquités Africaines III

FERRON, J. Y PINARD, M. 1955: «Les fouilles de Byrsa: 1953 54», Cahiers de Byrsa V

- 1960-61: Cahiers de Byrsa IX

FÉVRIER, J. 1956: Cahiers de Byrsa VI

FIGUERAS, F. 1946: «El grupo escultórico de Alicante», AEArq. XIX

- 1952: «Esquema de la necrópolis cartaginesa de Alicante», APL III

- 1956: La necrópolis ibero-púnica de La Albufereta de Alicante. Estudios Ibéricos IV, Valencia

FORTEA Y BERNIER, 1970: Recintos y Fortificaciones ibéricas en la Bética, Salamanca. 
FORTI, L. 1965: La ceràmica di Gnathia. Monumenti Antichi della Magna Grecia. Nápoles.

FUENTES, M. F. 1983: Aula Orientalis $I$.

GABRICI, E. 1927: Il santuario della Malophoros a Selinunte. Monumenti Antichi XXXII, Milán.

GARBINI, G. 1964: Monte Sirai I, Studi Semitici 11.

- 1980: I Fenici, Storia e Religione, Napoli.

- 1981: «Il sacrificio dei bambini nel mondo punico», Sangüe e Antropologia Biblica (ed. Vattioni) I, Roma.

GARCIA Y BELLIDO, A. 1943: La dama de Elche, Madrid.

- 1954: «Deidades Semitas en la España Antigua», Sefarad 24,1 y 2 .

- 1957: «El culto a la Dea Caelestis en la Península Ibérica», BRAH 140.

- 1958: «Imágenes de una deidad metroaca hispanorromana desconocida». AEArq. XXI.

- 1967: Les religions orientales dans l'Espagne Romaine, Leiden.

GAUCKLER, P. ET ALII, 1910: Catalogue des Musées et Collections Archéologiques d'Algérie et de la Tunisie. Musée Alaoui. Supplement. París.

- GAUCKLER, P. 1915: Nécropoles puniques de Carthage $I$, París.

GONZÁLEZ PRATS, A. 1986: «Las importaciones y la presencia fenicias en la Sierra de Crevillente (Alicante)», Los fenicios en la Península Ibérica.

GONZÁLEZ WAGNER, C. 1983: Fenicios y Cartagineses en la Península Ibérica. Tesis doctoral reprografiada. Madrid.

GSELL, S. 1924: Histoire Ancienne de l'Afrique du Nord IV.

HANS, L. M. 1983: Karthago und Sizilien. Hildesheim.

HIGGINS, R. A. 1954: Terracottas in the British Museum, Londres.

HUSS, W. 1985: Geschichte der Karthager, Munich.

HVIDBERG-HANSEN, F. O. 1979: La déesse TNT. Une étude sur la réligion canaanéo-punique. Copenhague.

IBARRA Y MANZONI, T. 1879: Illicis.

KUKAHN, E. 1962: «Los símbolos de la Gran Diosa en la pintura de los vasos ibéricos levantinos», Caesaraugusta 19-20.

- 1974: «Unas relaciones especiales entre el arte oriental griego y el Occidente», Simposio Internacional de Colonizaciones.

KURTZ C. Y BOARDMAN, J., 1971: Greek Burial Customs.

LAFUENTE, J. 1934: Excavaciones en la Albufereta de Alicante (antigua Lucentum), Memorias de la JSEA 126.

LAUMONIER, A. 1921: Catalogue des terrescuites du Musée Archéologique de Madrid. Madrid.

LEGLAY, M. 1975: «Les syncrétismes dans l'Afrique ancienne», Les Syncrétismes dans les Réligions de l'Antiquité. Colloque de Besançon. Leiden.

LÉVÊQUE, P. 1961: Greci e Italici in Magna Grecia, I Congreso de Tarento.

- 1973: «Colonisation grècque et syncrétisme», Les Syncrétismes dans les Religions Grècque et Romain, París.

LIDZBARSKI: Ephemeris für semitische Epigraphik II.

LINDER, E. 1973: «A cargo of phoenicio-punic Figurines», Archaeology 26.

LUZÓN, J. M. Y COIN, L. M. 1986: «La navegación preastronómica en la Antigüedad: utilización de pájaros en la orientación náutica», Lucentum, en prensa.

LLOBREGAT, E. 1972: Contestania Ibérica, Alicante.

- 1974: «Las relaciones con Ibiza en la Protohistoria Valenciana» Prehistoria y Arqueología de las Islas Baleares VI SPP.

- 1981: «Dos temples iberics a l'interior del poblat de l'Illeta dels Banyets», Fonaments $V$.
- 1983: «El templo ibérico de la Illeta dels Banyets, El Campello, Alicante» en BLÁZQUEZ, J. M. 1983, Apéndice IV.

- 1984: «Un altar de perfumes de tipo oriental en el yacimiento ibérico de la Illeta d'els Banyets (El Campello, Alicante)», Boletín de la Sociedad Española de Orientalistas $\mathrm{XX}$

- 1985: «El conjunto de templos ibéricos de la Illeta d'els Banyets (El Campello)», Studia Historica in honorem Vicente Martínez Morellà, Alicante.

MALUQUER, J. 1981: El santuario protohistórico de Zalamea de la Serena, Badajoz. Barcelona.

MARÍN CEBALLOS, M. C. 1977: La religión de los iberos, tesis doctoral inédita.

- 1978: «Documents pour l'étude de la religion phénicopunique dans la Péninsule Ibérique: Astarté», II CIEMO, Alger.

- 1981: «lbiza, encrucijada mediterránea: el panteón cartaginés», III CIEMO, vol. II.

- 1983: «La religión fenicia en Cádiz», Cádiz en su Historia, II Jornadas de Historia de Cádiz.

- 1983 b: «Una nueva interpretación de la pátera de Tivissa (Tarragona)», XVI CAN, Zaragoza.

MARTÍN, A. 1979: «El yacimiento indígena prerromano de Mas Castellà de Pontós (Girona)», XV CAN.

MARTÎN A. Y LLAVANERAS, N. 1980: «Un conjunt de timateris de terracuita amb representació de Demeter, procedent del Mas Castellá de Pontós» Cypsela III.

MERLÍN, A. 1910: Le sanctuaire de Baal et Tanit près de Siagu. París. Notes et documents publiées par la Direction des Antiquités et Arts.

MOSCATI, S. 1975: «Un bruciaprofumi di Tharros», Rivista degli Studi Orientali 49.

- 1975 b: Los Fenicios, Madrid.

- 1979: «Tanit in Fenicia», RSF 7.

- 1980: Il mondo punico, Torino.

- 1981: «La dea e il fiore», RANL 36.

- 1981 b: «Un bilancio per TNT», OA 20.

- 1986: Le stele di Sulcis. Caratteri e confronti, Roma.

MOURET, F. 1929: CVA. France, n. ${ }^{\circ}$ 6. Collection Mouret (Fouilles Ensérune), París.

MUÑOZ, A. M. 1963: Pebeteros ibéricos en forma de cabeza femenina (De coroplastia ibérica I), Barcelona.

- 1968: «Sobre el comercio cartaginés en España», Pyrenae 4.

- 1985: Comunicación al congreso sobre Mundo Ibérico, Jaén, en prensa.

NICOLINI, G. 1973: Les Ibères. Art et Civilisation. Paris.

NIETO, G. 1939-40: «Noticia de las excavaciones realizadas en la necrópolis hispánica del Cabecico del Tesoro, Verdolay (Murcia)», BSEAA VI.

- 1942-43: «La necrópolis hispánica del Cabecico del Tesoro, Verdolay (Murcia)», BSEA $A$ IX.

- 1943-44: «La necrópolis hispánica del Cabecico del Tesoro, Verdolay (Murcia)», BSEAA X.

NORDSTROM, S. 1969: La céramique peinte ibérique de la province d'Alicante II, Estocolmo.

OLIVA, M. 1955: AIEG X.

- 1956-7: $A I E G \mathrm{XI}$.

- 1959: AIEG XIII.

- 1967: Ullastret. Guía de las excavaciones y su Museo. Girona (2. $\left.{ }^{a}\right)$.

OLMOS, R. 1987: «Aportaciones iconográficas a las copas del siglo IV a. de C. de Cástulo: conjeturas púnicas», Castulo $V I$ en prensa.

ORLANDINI, P. 1966: Kokalos 12. 
PALLARÉS, R. ET ALII, 1986: «Presencia de culto griego en la desembocadura del Ebro. Representaciones de Demeter en el Museo Municipal de Reus», Saguntum 20.

PENA, M. J. 1973: «Artemis-Diana y algunas cuestiones en relación con su iconografía y su culto en Occidente», Ampurias 35 .

- 1986: «Los thymiateria en forma de cabeza femenina hallados en el Noreste de la Península Ibérica», Table Ronde: Grecs et Ibères en IVème siècle av. J-C: Commerce et Iconographie, Bordeaux, en prensa.

PESCE, G. 1961: Sardegna Punica, Cagliari.

PICARD, C. 1957: Catalogue du Musée Alaoui. N. S. Coll. Puniques. París.

- 1965-6: «Sacra Punica», Karthago 13.

- 1969: «Tanit Courotrophe», Hommages à M. Rénard III. Col. Latomus.

- 1970: Studi Magrebini III.

- 1976: «La Dame des brûle-parfums à Carthage», Homenaje a García y Bellido. Madrid.

- 1979: «Les représentations du cycle dionysiaque à Carthage et dans l'art punique», Antiquités Africaines XIV.

PICARD, G. 1954: Les Religions de l'Afrique Antique, París.

DE LA PINTA, J. L. Y MIRANDA, J. 1981: El poblado layetano de Puig Castellar. Museo Municipal Puig Castellar. Sta. Coloma de Gramanet. Barcelona.

PRESEDO, F. 1973: La Dama de Baza, Madrid.

PRITCHARD, J. B. 1978: Recovering Sarepta. A phoenician City, Princeton.

PUIG I CADAFALCH, 1915: «La colonia grega d'Empuries», AIEC VI, Barcelona.

PUJOL, A. 1984-85: «El comercio de Emporion», Studia Historica II-III, n. ${ }^{\circ} 1$.

QUINTERO, P. 1932: Excavaciones en Cádiz. Memoria de las excavaciones practicadas en 1929-31, JSEA 117.

RAMÍREZ, J. R. Y MATEOS, V. 1982: «La arqueología subacuática en la Bahía de Cádiz», VI Congreso Internacional de Arqueología Submarina, Cartagena.

RAMOS FERNÁNDEZ, R. 1982: «Precisiones para la clasificación de la cerámica ibérica», Lucentum I.

RAMOS FOLQUÉS, A. 1970: Excavaciones en la Alcudia (Elche), Trabajos Varios del SIP n. ${ }^{\circ} 39$, Valencia.

- 1976: Excavaciones en la Alcudia de Elche durante los años 1968-1973, E. A. en España 91.

RAMOS, A. Y RAMOS, R. 1976: «Excavaciones al Este del Parque Infantil de Tráfico en Elche (Alicante)» $N A H 4$.

RÉNARD, M. 1959: «Nutrix Saturni», Bulletin de la Société National des Antiquaires de France.

REVERE, R. B. 1976: «Tierra de nadie: los puertos comerciales del Mediterráneo oriental», en K. POLANYI (ed.) Comercio y Mercado en los Imperios Antiguos, Barcelona.

RICHTER, G. M. 1966: The Furniture of the Greeks, Etruscan and Romans, Londres.

RIIS, P. J. 1950: «La estatuilla de alabastro de Galera», Notas del Seminario de Estudios de Historia Primitiva del Hombre.

RIPOLL, E. 1969: Ampurias. Guía itineraria. Barcelona.

RUBIO GOMÍS, F. 1986: La necrópolis ibérica de La Albufereta de Alicante (Valencia, España) Valencia.

RUIZ, A. Y MOLINA, F. 1982: «El conjunto de terracotas de una tumba romana de Almuñécar, Granada», $M M 23$.
SANMARTÍ, E. Y GUSI, F. 1975: «Nuevos materiales procedentes del poblado ibérico del Castell (Almenara)», Cuadernos de Prehistoria y Arqueología Castellonense 2

SAN NICOLÁS, P. 1981: "Testimonio del culto a DemeterPerséfone en Ibiza» AEArq. 54.

SANTERO, J.: Cuadernos de Trabajo de Historia de Andalucía I: Prehistoria y Antigüedad. De la crisis de Tartessos a las Guerras Púnicas. Carpeta 1, tema V, 14.

DE LOS SANTOS, S. 1950: Guía del Museo Arqueológico de Córdoba, Madrid.

SANTOS, J. A. 1983: «La denominada necrópolis ibérica de Orán en el MAN», Trab. de Preh. 40.

SERRA RAFOLS, 1941: «El poblado ibérico del Castellet de Banyoles, Tivissa, Bajo Ebro», Ampurias III.

SESTIERI, P. 1955: «Iconographie et culte d'Hera à Paestum», La Révue des Arts.

TARRADELL, M. 1949: «Estado actual de los conocimientos sobre Tamuda y los resultados de la campaña de 1948», AEArq. XXII, 86-100.

- 1956: «Las excavaciones de Tamuda de 1949 a 1955», Tamuda VI, 1.

- 1968: Arte Ibérico, Barcelona.

- 1973: «Cuevas sagradas o cuevas santuario: un aspecto poco valorado de la religión ibérica», Memoria de la Univ. de Barcelona.

- 1981: «El poblat ibèric del Tossal de la Cala de Benidorm. Notes d'excavació», Fonaments $V$.

TARRADELL, M. Y FONT, M. 1975: Eivissa Cartaginesa, Barcelona.

TUSA, A. 1968: «Vaso bronzeo bifronte de Mozia», O. A. VII, 1.

TUSA, V. 1971: «Selinunte punica», Rivista dell Instituto Nazionale d'Archeologia e Storia dell Arte XVIII, n. s.

UBERTI, M. L. 1975: «Le terrecotte», Anecdota Tharrica, Roma.

- 1975 b: «Su un trono di Astarté a Mozia», Saggi fenici I.

- 1977: La collezione Biggio. Antichità Puniche a Sant' Antioco, Roma.

UGOLINI, D. 1983: «Deux thymiateria à tête fémenine du Musée d'Ensérune), Documents d'Archéologia Meridionale 6.

DE VAUX, R. 1967: «Les Chérubins et l'Arche d'Alliance. Les sphinx gardiens et les trônes divins dans l'ancient Orient», Bible et Orient. París.

VILASECA, L. 1953-4: «Hallazgos helenísticos en Camarlés (Tarragona)», Ampurias XV y XVI.

VILASECA, S. 1956: Comunicación de Sta. Coloma de Gramanet, Informes y Memorias 7, Madrid.

VISEDO, C. 1923: Excavaciones en el monte de La Serreta, próximo a Alcoy (Alicante), Memorias de la JSEA 56.

DI VITA, A. 1953: «L'elemento punico a Selinunte nel IV e nel III sec. a. C.», Arch. Class. V, 1.

- 1961-64: «Le stele puniche del recinto di Zeus Meilichios a Selinunte», Atti del Convegno di Studi Annibalici. Estratto del Annuario dell'Accademia Etrusca di Cortona N. S. V.

VIVES, A. 1926: La moneda hispánica, Madrid.

WALTER, H. C.: «Sphingen», Antike und Abendland IX.

WHITE, D. 1967: «The post-classical Cult of Malophoros at Selinus» $A J A 714$.

XELLA, P. 1969: «Sull introduzione del culto di Demetra e Kore a Cartagine». Studi e Materiali 40, 1-2.

ZUNTZ, G. 1971: Persephone, Oxford. 